\title{
Agricola's Ukko in the light of archaeology \\ A chronological and interpretative study of ancient Finnish religion
}

\author{
By Unto Salo
}

\begin{abstract}
Sources
No written sources of ancient Finnish religion have been preserved from the pre-Christian period. Study of the subject is thus based on later historical data, folk poetry and other recorded national traditions, supplemented by etymology and onomastics. A valuable basis for study is provided by the celebrated, if brief and partly obscure, verses of Mikael Agricola in the preface to his Psalms of David from 1551. Here Agricola lists the gods of Karelia and Häme. He admittedly subjects them to Christian censure, but he is also in these verses the first systematizer and the first theologian of our ancient religion; in actual fact, he created twin Olympuses of the old religion, two anthropomorphic god-worlds, the sub-structure of which includes the worship of spirits, animals and the dead (e.g. Harva 1948, 1-21).
\end{abstract}

\section{The Olympuses}

The sources of our ancient religion are thus from a later period, it is true, from a time when the old beliefs were still flourishing as popular culture, although they had been transformed by centuries of Christian influence. According to Martti Haavio, most of the Karelian gods were in fact fallen saints from a Christian background (Haavio 1959). Haavio bases his theory mainly on etymologies which may be characterised as highly ingenious, whether or not they are actually correct; up to the present time, they have not been submitted to critical examination. It is nevertheless clear that the special tasks of the Karelian gods would presumably have been better suited to the saintly flora of monastery gardens than to the pagan products of village growth. They require, in my opinion, more specialized religious thought or mythology than night be expected under our conditions from a purely pagan religion. In this respect, ancient Finnish religion does not seem to have led to such highly evolved, 
cult-based institutions that their maintenance would have demanded specialized individuals, priests or monks; one form of witchcraft with deep roots in pre-history, the practice of shamanism, is not founded on myths and is not, in this sense, cult-based.

It is in any event clear that the differences between the respective Olympuses of the Tavastians and the Karelians cannot be explained merely on the basis of the brevity and oversimplicity of Agricola's verses and this was probably never done. The account must to a large extent be factual and thus have a genuine historical basis. Haavio identifies the latter as Christian influences which would have reached Karelia perhaps as early as the 9 th and 10 th-centuries from the diocese of Hamburg-Bremen, either directly or perhaps through the mediacy of Birka; according to Haavio, several Karelian gods correspond in both name and function to the patron saints of this area.

Haavio's hypothesis of the North Sea origins of the Christian-based gods of Karelia would fit admirably with Jalmari Jaakkola's theory of Friesian influence spreading to Finland via Birka during the Viking period (Jaakkola 1935, 80-85, 173-181). Jaakkola's arguments, based among other things on the supposition that the kugg names along the coast denote Friesian origins, are now however no longer accepted, and there is no clear evidence among finds from the Finnish Viking period to suggest any direct Friesian influence (Leppäaho 1949b, 68 f.; Nordman 1942). And since the Friesian contribution to the foundation of Birka does not appear to have been so decisive as was previously thought, Haavio's underlying assumption is in a way left hanging in the air.

Some chronological support may nevertheless be obtained from the locally produced round brooches which occur in archaeological finds from around the year 800 (Salo 1987) (Fig. 1). Their Christian symbolism and clearly geometricized floral ornamentation suggest that the smiths who made them were familiar with Christian art and its symbols and also consciously tried to represent them; for this reason, their round brooches may be regarded as the earliest indicators of Christianity in Finland. They are more or less from the period corresponding to Ansgar's Birka mission, but do not appear to be connected with Birka's Christianity. No similar objects are known from this region, or from anywhere else in the Baltic area, except for a few round brooches found in Lithuania, but these do not display any Christian features. It is thus difficult to connect Finnish round brooches with the Hamburg-Bremen influence, and the question of Karelian gods is also problematic, since the brooches are more common in Western Finland 


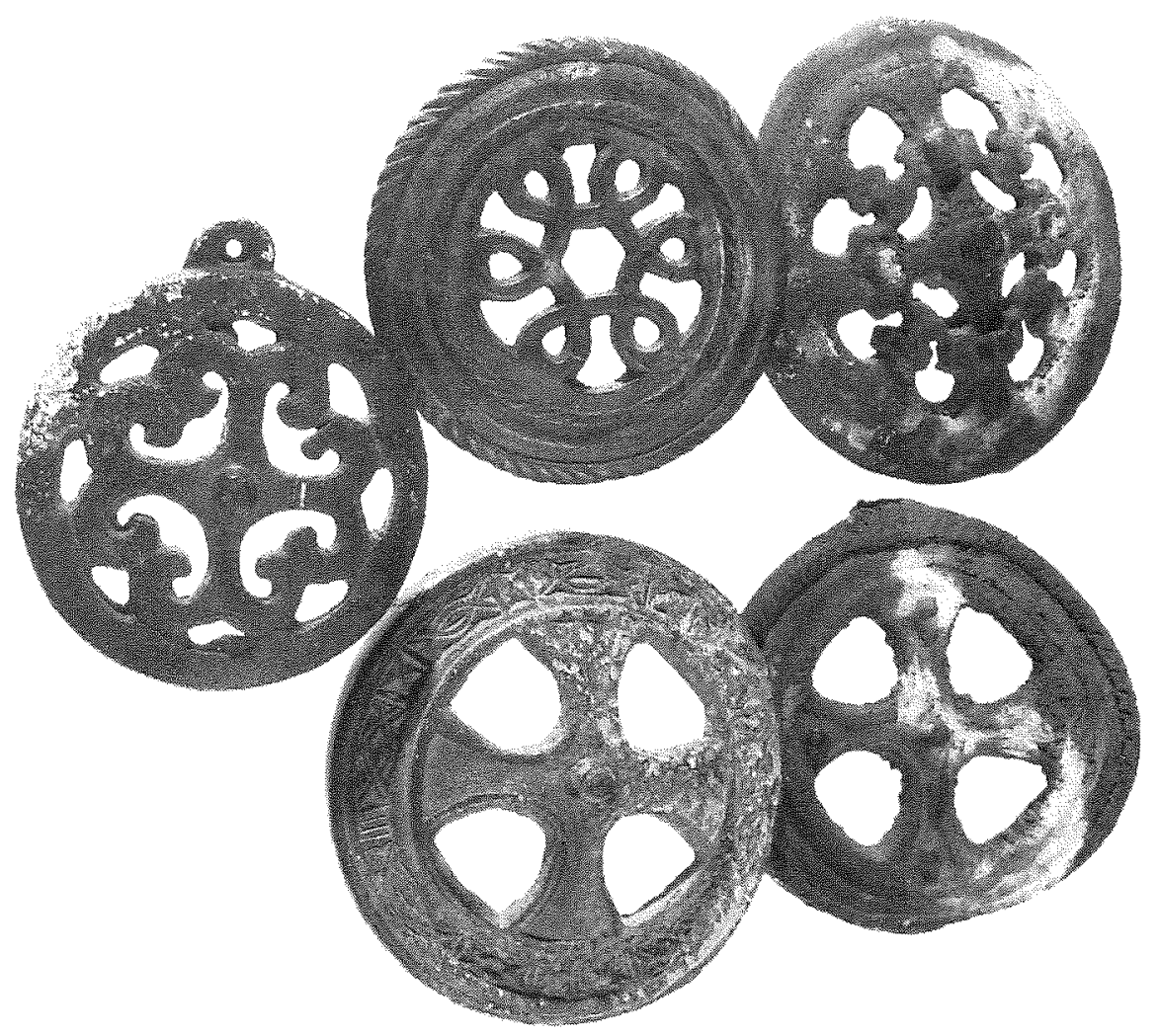

Fig. 1. The early influence of Christianity in Finland is reflected in finds of ringbrooches from ca, 800 A.D. The ornaments of these go back to symbols found in early Christian art: the victor's wreath with the equal-armed cross within the circle, the anchor motif on the convoluted cross buckle. The multilooped central ornamentation of the brooch probably goes back to the quadrilooped symbol of John the Baptist. The central six-armed decoration also has its counterpart in early Christian art, and may be considered a simplification of a Christogram but it may equally well come from the wheel motif. On the left is a convoluted cross brooch from Lopotti, Kurkijoki (Karelia, USSR), at the bottom circular cross brooches from Papinsaari, Kuhmoinen and Kylänmäki, Laitila, at the top a St John's shield brooch from Hattelmala, Hämeenlinna and another circular cross buckle from Puttola, Jämsä. National Museum, Helsinki. Photo: R. Bäckman, National Board of Antiquities.

than in Karelia. As far as the time factor is concerned, however, they would fit well with Haavio's hypothesis. They could also be linked with the Karelian gods on the grounds that their symbolism undergoes a decline with the coming of the Viking Age, which must also mean some 
eclipse of the corresponding Christian concepts; in the same way, the saints mislaid their Christian features and became transformed into Karelian divinities, if Haavio's interpretation is correct.

The number of true pagan gods among those mentioned by Agricola would thus be largely confined to the gods of Häme, including Väinämöinen, Ilmarinen, Ahti and Tapio, familiar from ancient poetry. Among the gods of Karelia, Ukko, Hiisi and the Water Mother would go back to an earlier period. At this point, I would not like to judge which of these figures were more champions or cultural heroes than gods.

\section{Substrata and conceptual alternatives in ancient religion}

Since the sources for ancient religion do not go back beyond Agricola's psalter, our concept of the subject may be compared to the sediment of a river bed, where the deposits of the different periods are not really separable. Except for a surface layer coloured by Christianity, for which it has not been possible to suggest dates, it is non-historical, "ancient" or "timeless". Our early religion is thus to a large extent without chronology. But since it must have its chronological strata, research should attempt to distinguish them, in spite of the difficulty of the task and the wide range of possible interpretation. Where ancient religion is concerned, I believe it is possible to provide a rough but broad-based perspective for pre-history.

According to a general consensus, certain features in early Finnish religion have of course been distinguished as primitive or evolved, but it has not been possible to attach these to any particular period. There are at least three such substrata. The most recent is formed partly or completely by paganised saints $o_{\text {. }}$ divinities, in addition to beliefs and concepts which reveal Christian influence, but have nevertheless become detached from their Christian background. Older than this are the pagan anthropomorphic gods and divine heroes. The oldest substratum includes sprites or spirits linked to a particular place and beliefs connected with the dead, as well as impersonal forces or powers found in natural elements such as earth, water, forest or fire; the idea of power would appear to include the notion of a mutual link with natural objects or phenomena, a concept reduced by natural science to the ultimate identity of matter and energy. These strata lived side by side, however, in ancient times, and even the oldest seems to have appropriated foreign cultural elements right into historical times. 
In the chronology of early religion it is a matter of dating such substrata or more circumstantial features. To do this, one may of course only use sources which are related to a belief or cult, and which return to a pre-historical period, when they have been organized into chronologically consecutive groups. This is principally a question of linguistic and archaeological material. The perspectives of historical linguistics have often been applied to early Finnish religion, if not on a systematic basis. One difficulty has been the inexactness of linguistic chronology, the fluctuations arising from this, and the resultant conflict with archaeological chronology. In recent times, in the work of Jorma Koivulehto among others, this chronology has come gratifyingly close to that of archaelogy (cf. Koivulehto 1973).

Archaeological sources have been used less, because they are more alien to students of early religion. On the one hand, in Finland very little of the available religious and cultic material has been understood, the obvious exceptions being graves and burial customs, as well as certain emblems from the late Iron Age, some Christian and others interpreted as pagan. Archaeologists have been bound in this respect by the notion that hypotheses based on beliefs or cults are an extreme measure, only to be adopted when there are no alternatives; religious interpretations have thus been regarded as not really belonging to the sphere of rationalistic and positivistic research. At the same time, they have been rejected because of the uncritical facility with which research once relied on religious and cult-based explanations. Students have also been checked by a healthy caution; every hothead who goes off on adventures outside the safe paths of his own discipline obviously runs the risk of stumbling, if not of an actual fall.

Another weighty reason is Alfred Hackman's well-grounded settlement theory from the beginning of the century (Hackman 1905, 189$359)$. Since, according to this theory, Finnish settlement in the country only dates from the Roman period onwards, no material older than this can possibly be connected with Finnish religious history. The potentially valuable support offered by archaeology, a science capable of providing a chronology, could not therefore be adequately used. This obstacle has now been largely removed since views on the history of settlement have changed (Meinander 1954a; Meinander 1954b; Meinander 1969; Meinander 1984; Salo 1981; Salo 1984a; Salo 1984b; Salo 1984c).

According to these, Finnish society and Finnish culture were formed in Finland. An unbroken continuity of settlement can now be traced back to the very beginning, more than nine millenia ago. Continuity of 


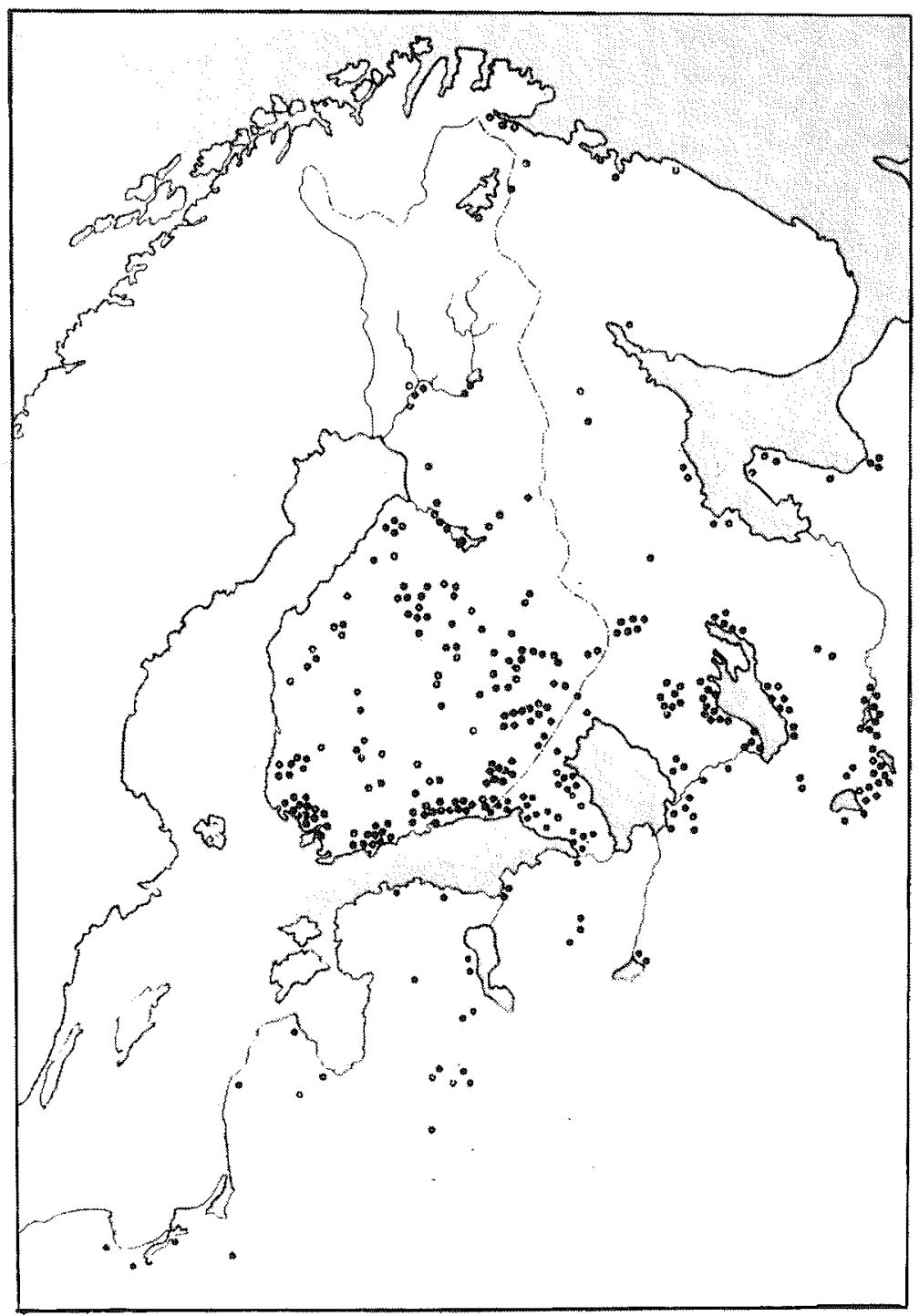

Fig. 2. Early comb-ceramic settlements according to C. F. Meinander. Present beliefs hold that the original language of the Balto-Finns, proto-Finnish, spread to the Baltic, Ladoga and Onega areas with typical comb-ceramic migration about 3300 B.C. since no earlier and no later prehistoric culture common to the BaltoFennic area that could suitably have served as the foundations of proto-Finnish culture is known in the area. The influence of the earlier population of the area is probably reflected in the numerous proto-Finnish words for which no earlier etymology has been proposed and which have not been shown to be loans from Indo-European languages. National Museum, Helsinki. 


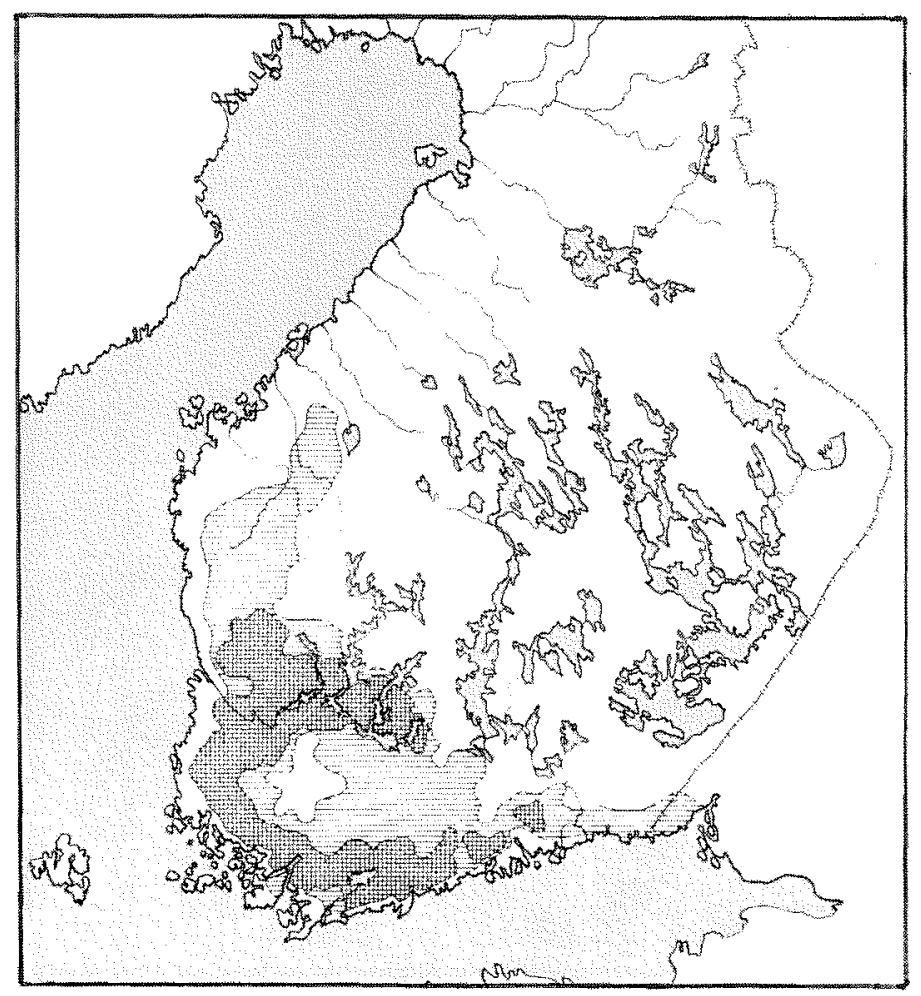

Fig. 3. The distribution of battle-axe culture in Finland according to C. F. Meinander. Battle-axe culture, which spread to Finland from the south (ca. 2500-2000 B.C.) is often considered to be proto-Baltic. National Museum, Helsinki.

settlement does not in itself, however, mean continuity of the ethnos, but the kind of cultural activity which makes the continuity of the ethnos likely may be traced in Finland for at least four thousand and possibly over five thousand years. The history of the Finnish ethnos, as far as may be judged from continuous features of settlement and culture, goes back at least to the final phase of the Stone Age, to the beginning of the Kiukais-culture (2000-1400/1200), but it would appear to go back even further, i.e. right to the comb-ceramic period proper, ca. 3300-2800, according to present theories (Fig. 2). Combceramics proper seem to have spread to Finland and Estonia together with a population which may be regarded as Fenno-Ugrian. According to recent Estonian research, it seems to have brought the Finnish ethnos to Estonia. It does not follow from this, however, that the same condition also applies to Finland, since a Fenno-Ugrian element 


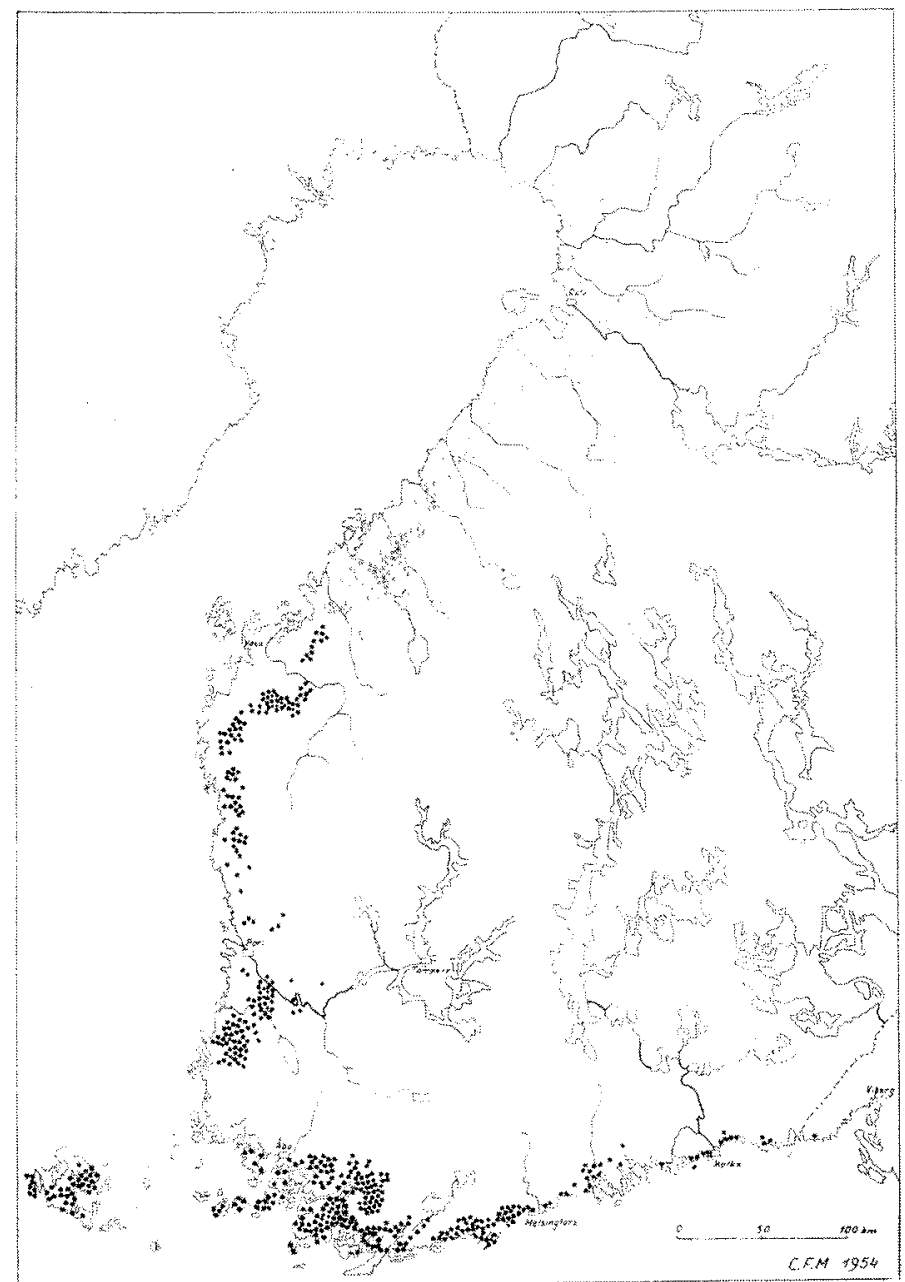

Fig. 4. Distribution of grave mounds typical of the Bronze Age and early Iron Age (ca. 1300 B.C. - 500 A.D.) along the Finnish coast according to C.F. Meinander. Grave mounds seem to have spread about 1300-1000 B.C. from the west with migrating proto-Germanic tribes. The old proto-Finnish peoples of the coast adopted the custom and the new social structure associated with it at the latest around 1000 B.C. (Meinander 1954b).

may have been present in the population from the very beginning.

In spite of this continuity, the history of settlement in Finland was not straightforward after the comb-ceramic wave. A battle axe culture spread from the South to the South West areas of the country included an Indo-European, probably proto-Baltic population, which left the 


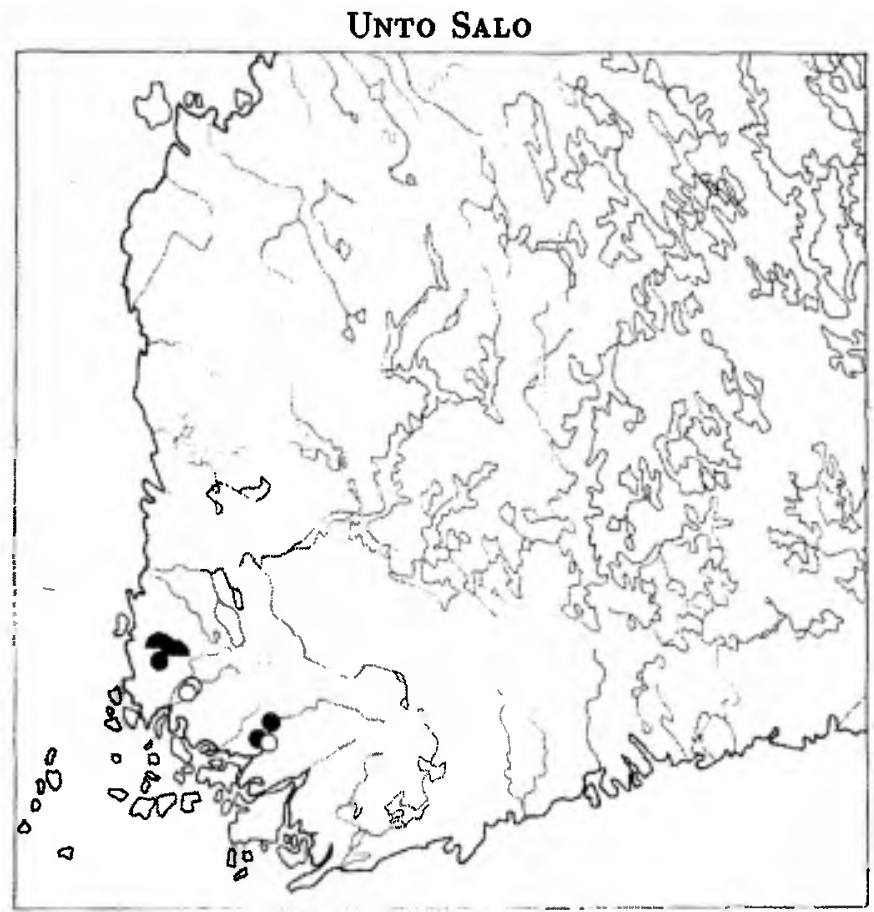

Fig. 5 has been replaced due to a mishap in the original printing.

Fig. 5. Swedish-type burial grounds of early Roman times (50-200) provide ev idence of immigration from the west, or perhaps of other contacts. The burial grounds in question are limited to the central and northern parts of Finland Proper (Salo 1968).

Fenno-Baltic languages with a rich stratum of words (Fig. 3). After the middle of the second millenium, numbers of proto-Germans from the West seem to have reached the coast in the middle of the proto-Finnish population, bringing with them a new social structure, the farmhouse based on family ownership (Fig. 4). The influence of these arrivals is reflected in the proto-Germanic word stratum of the Finnish language, and apparently also in the history of its phonology. In the early Roman period some proto-Scandinavian groups, perhaps predominantly male, settled in the central and northern districts of Finland Proper (Fig. 5). More intensive and widespread was the Swedish colonisation of the thirteenth and fourteenth centuries, directed towards the coastal regions, and also - judging by place names - to the interior of the country; according to Erik's Chronicle, it was organized by Birger Jarl and later also supported by the Crown.

These migrations of early history and pre-history doubtless affected the racial composition of the population, but they had an even stronger 


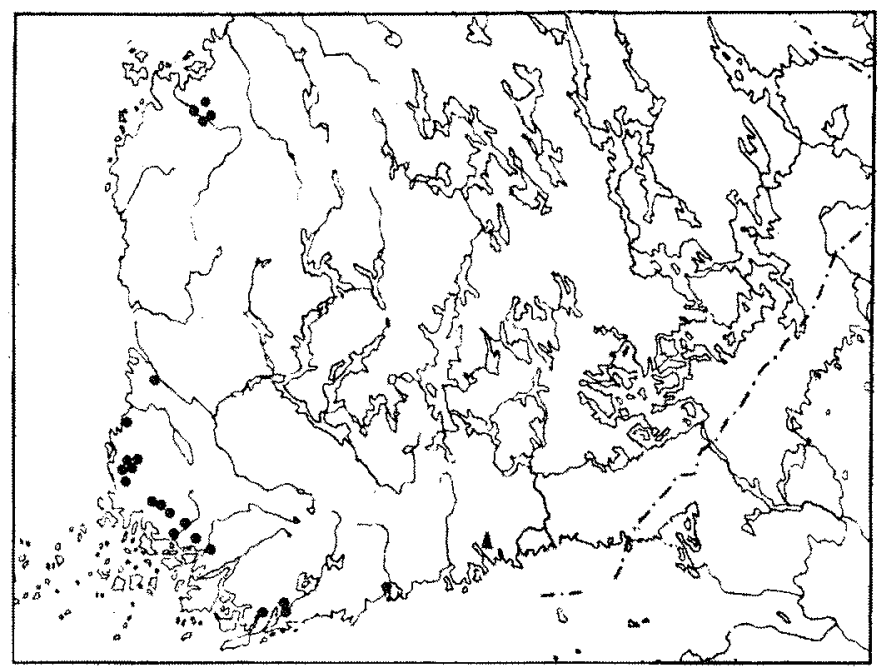

Map fig. 6.

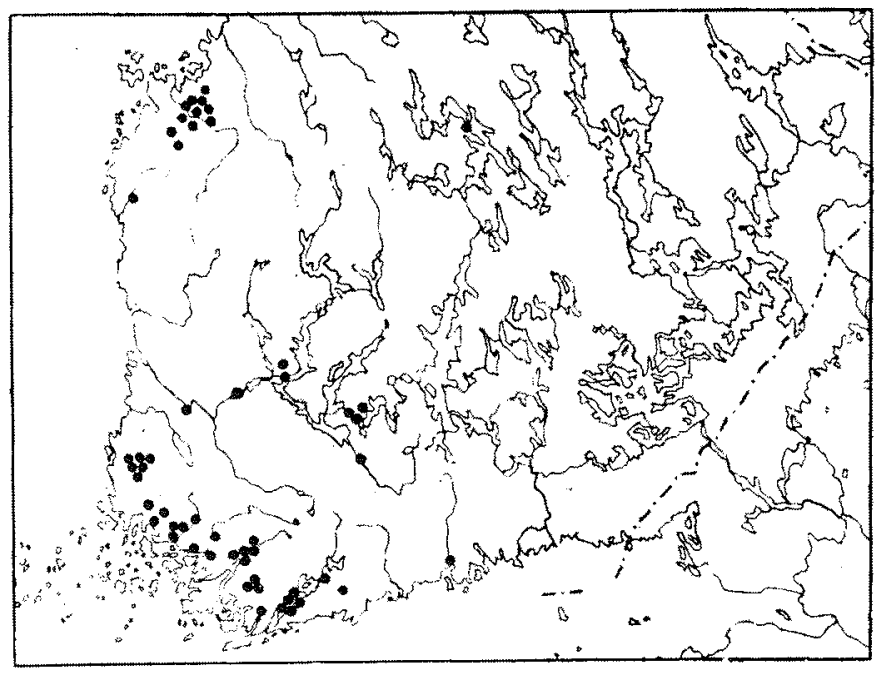

Map fig. 7. 


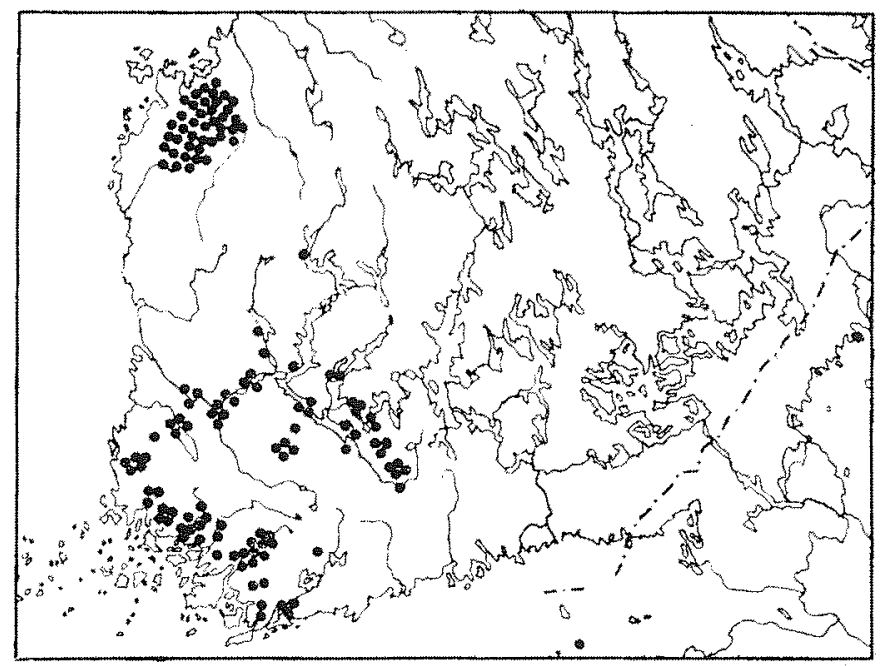

Map fig. 8.

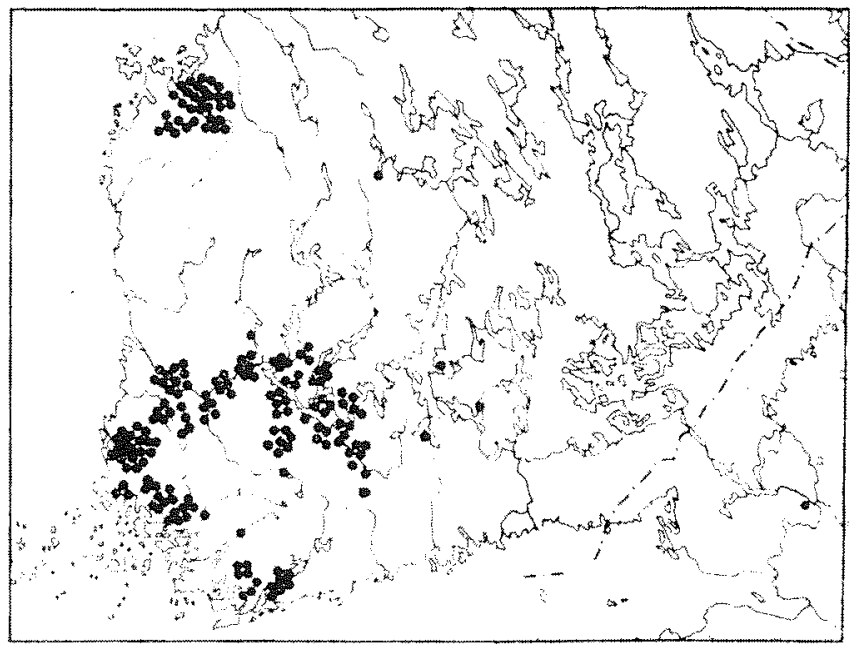

Map fig. 9

Fig. 6-9. Iron Age burial grounds from early (50-200) and late (200-400) Roman times, the great migration period (400-550) and the Merovingian period (550-800). The density and distribution of the burial grounds reflects the expansion of peasant settlements and evidently its organisation into parishes. 


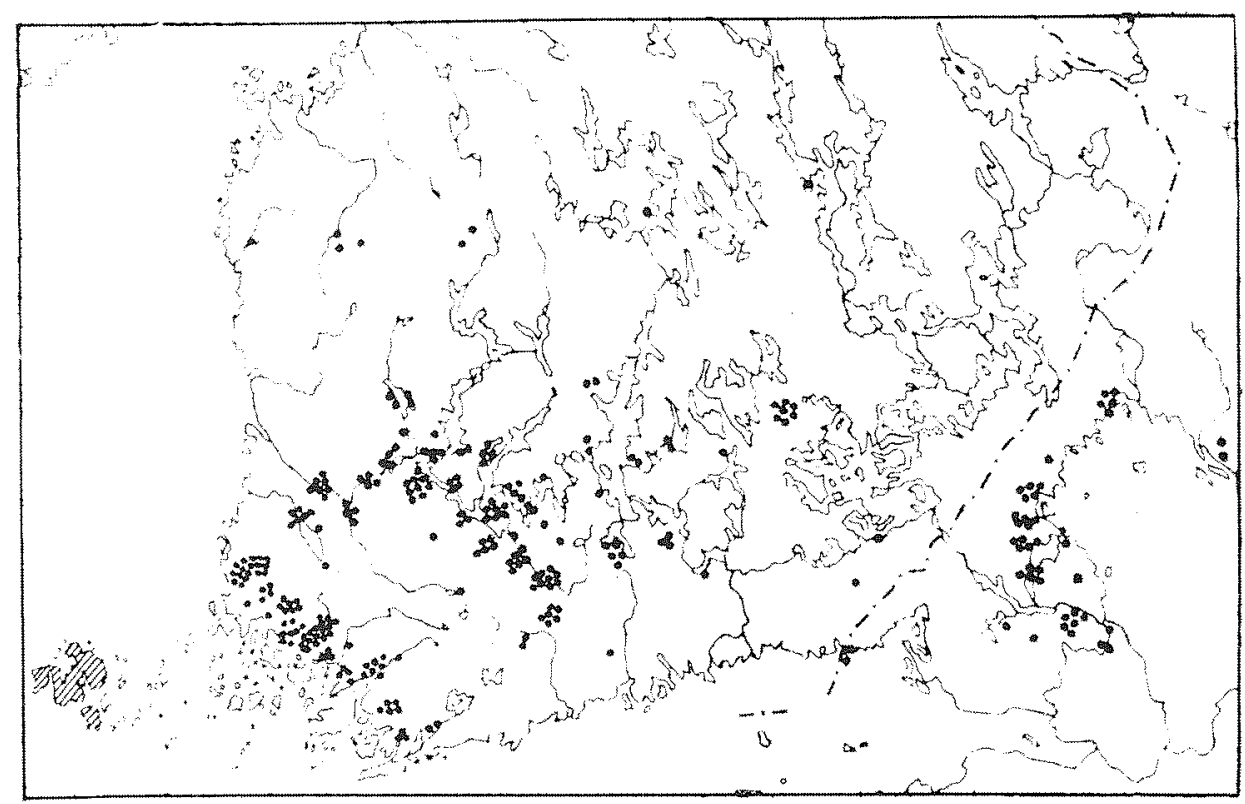

Fig. 10. Burial grounds from the Viking and crusade periods $(800-1150 / 1300)$. There were permanent settlements on Aland, along the coast of Finland Proper, along the Kokemäenjoki watercourse, in Savo and on the banks of Ladoga in Karelia, (Kivikoski 1961).

influence on language and culture. These traces, together with the continuity of the Finnish ethnos for thousands of years, are also reflected in ancient religion. This may now be studied simultaneously from the perspective of a Finnish ethnic continuity which has lasted for four or five thousand years and in the light of these migrations. With this material it may be possible to sketch a hitherto non-existent history of Ukko, the ancient Finnish god of thunder.

\section{Agricola's Ukko}

From the point of view of archaelogy, Agricola's Ukko, 'old man', is one of the most interesting figures in ancient religion. The verses referring to him as follows: 
Ja quin kevekyluö kyluettin/ silloin ukon Malia jootijn.

Sihen haetin ukon vacka/ nin joopui Pica ette Acka.

Sijtte palio Häpie sielle techtin/ quin seke cwltin ette nechtin.

Quin Rauni Ukon Naini härsky/ ialosti Ukoi Pohiasti pärsky.

Se sis annoi Ilman ja Wdhen Tulon/

And when the spring-sowing was done/ then the old man's toast was drunk.

For this was Ukko's wooden vessel fetched/ and the girl and the wife got drunk.

Then were shameful things done there/ as was both heard and seen.

When Rauni Ukko's woman huffed/ Greatly puffed Ukko from the depths.

Thus it gave weather and the new crop.

According to the traditional interpretation, the Ukko whose toast was drunk was the same Ukko that gave "weather and the new crop". By describing his cult and his activities in nine lines - the other gods only receive one or two lines - Agricola effectively places him at the summit of the Karelian Olympus, without actually saying so. His grounds for doing so may have been the general importance of Ukko, since there was probably no real hierarchy of gods at the time; there were either divinities of major importance, sometimes to be feared, or those of minor importance, whose significance was linked with a particular occasion. The length of Agricola's description may also have been influenced by the fact that Ukko's toast was drunk in Eastern Finland, and even in Häme, too, at a relatively late period (Harva 1948, 103-122), which in itself of course suggests the importance of Ukko. According to Agricola, Ukko was (only) a Karelian god, but scholars have long considered that he was referring to the universally feared Ukko, Ukkonen, the god of thunder, who would have fitted equally well among the gods of Häme (Tavastland) (Harva 1948, 74102). 


\section{Martti Haavio's interpretation}

That ingenious dissenter, Martti Haavio, nevertheless reached the conclusion that the lines, besides referring to the drinking of Ukko's toast, also described the hieros gamos, or "holy marriage" of Ukko and his bride which increased the fertility of the land. He based his interpretation on a highly versatile analysis of the obscure verses in the poem. He referred first to the fact already established by previous research that the same ukko, literally "old man", was an honorary name, given in old runes to other divine figures, and not therefore only a name for the god of thunder. Rauni was not, in his view, the name of Ukko's wife, as was previously supposed, but was joined to Ukko as an epithet: it was thus a question of Rauni-Ukko.

This interpretation accounted for the strange circumstance that genuine folk tradition has absolutely nothing to say about Rauni. According to Haavio, Rauni was a continental-Germanic adjectival loan. $\mathrm{He}$ also demonstrated convincingly that the verbs härskyä and pärskyä, the modern meanings of which are obscure, have acquired in several dialects the general sense of the "huffing and puffing" of rutting animals. It then "ukon Naini härsky" - Ukko's bride huffed - rutting Ukko, in turn, puffed vigorously, even "greatly"; and the curious "Pohiasti", for which different explanations have of course been suggested, simply meant "pohjasta" or "from the bottom". The "bottom" in turn was the "bottom of the field", and this was the abode of the sleeping "boy", Sampsa or Pellervoinen, who - in some ancient runes - seduced the "old woman from beneath the earth" or his stepmother in order to increase the fertility of the land. It is the same holy marriage familiar from many rebirths of fertility gods in the Mediterrenean, and from the myths describing the copulation with the mother, and not only from these, but also from Scandinavian mythology. Since the line "Se sis annoi Ilman ia Wdhen tulon" it thus brought weather and a New Coming meant, according to Haavio, the provision of favourable weather and a new coming or harvest, besides being linked with the holy marriage of Ukko and his bride, Haavio may have regarded his demonstration as virtually complete. Ukko the Thunder God does not appear at all then in Agricola's Olympus, according to Haavio, although he does occur in certain ancient runes, i.e. as the killer of the great ox or of the corresponding great pig (Haavio 1959, 81-102). 


\section{Other studies of Ukko}

Haavio's ingenious interpretation represents an almost total reversal of previous hypotheses and opens new perspectives to scholarship. One of Haavio's most remarkable insights is the notion of a Holy marriage between Rauni-Ukko and his bride. The actual basic idea may however be mistaken. According to the traditional and - in my opinion better founded notion, Agricola's verses do in fact describe the thunder god, Ukko. A number of viewpoints may be suggested, and most of these have long been familiar. To begin with, I shall provide a brief account of the thunder god as conceived by earlier scholarship, especially E. N. Setälä (Setälä 1910), Kaarle Krohn (Krohn 1914, 116126), Uno Harva (Harva 1948, 74-102) and Martti Haavio (Haavio 1959, 95-102; Haavio 1961).

1. The god's name throughout the country is generally Ukko, Ukkonen, "old man, old fellow", but in different areas he is also known as Isoi, Isäinen, Isänen, "father", or by the rarer but older name of Äijä, "old man", variants of which are known in Lapland and Estonia, as well as Pitkänen, Pitkäinen, Pitkämöinen, apparently "distant coming or striking from afar" in Finland Proper (and Estonia). Sometimes the circumlocution vanha mies (old man) is used, and in Vermland Ylkäinen and Ylikäinen, "the one above" have been recorded. The ancient runes of Russian Karelia also mention Tuuri. The diminutive forms of names may be due to a fear of thunder, but $I$ also presume that, with the exception of the last example, the names should be interpreted as euphemisms induced by fear. One may thus ask whether the god ever had a real name, although - if he had - in winter, at least, there would have been no danger in uttering it.

2. Ukko's domain is the clouds. He is "lord above", "the master of the clouds", the raiser of clouds.

He pursues, thunders, raises the wind or makes lightning ("Ukko of the sky struck fire, Väinämöinen flashed lightning"). He controls "the weather" ("holy Ukko father of the weather", Hauho 1662) or stormy weather, the roughest weather. Uklio also produces rain and especially rain with thunder (Isänen's shower - "the father's shower"). The rainbow is known, in Finland Proper at least, as Ukko's arch, but the equivalent name also exists in Lappish.

Ukko sometimes started a fire, which - to distinguish it from other fires - was known as the white fire of Pitkäinen or Ukkonen. It could 
be prevented by Ukko's own weapons, the thunderbolts, and it could also be extinguished by the same means or by a woman's milk.

Ukko also increased fertility. Pitkänen's cast, i.e. lightning, "oh sorely welcome to earthly growth"; according to Agricola (the distant one), who makest all afraid, breakest/ and turnest/ and makest the earth fruitful" (Gospel according to St Mark, New Testament, 1548).

The real nature of inducing fertility becomes apparent, as I understand it, from such expressions as "Ukko panee", "Isänen panee" (Renvall's dictionary 1826) or from a line in Siimon Paavalinpoika's funeral elegy from 1704 "Joco nyt pitkänen panepi" (And lays the thunder now).

These may be compared with the common expression "halla panee" (frost "lays"); it should of course be noted that the verb, panna (put or - in a sexual sense - lay) is used in many ways, so that other possible interpretations naturally exist. Putting out Ukko's fire with woman's milk nevertheless suits the interpretations suggested above, since the woman's milk is the result of a sexual act.

3. Ukko was also an all-purpose god, invoked in many different situations, such as childbirth, hunting and in staunching the flow of blood.

4. Ukko's attributes included a blue cloak. Setälä has also pointed out that Ukko is "hattaroiden hallitsija" (master of the clouds) and that the Finnish word hattara (cloud) is apparently a loan from the Swedish hattar, which is also connected with the thunder god, as in gofar hattar and aska-hattar (the old man's hats or clouds). In Sweden, the attributes of thunder god perhaps included a hat, but this was hardly the case in Finland; hattara may have been borrowed from a plural form of the word and thus refer to hat-shaped clouds or cumulus. The name of the flower ukonhattu (wolf's bane), in Swedish stormhatt (Lönnrot's dictionary), would thus be explained by the hat of the thunder god, but may be a later development. In any case, Ukko's connection with the hattara-clouds is in my opinion a Western feature, although SKES (The Etymological Dictionary of the Finnish Language) offers the hypothesis that the origin of hattara (cloud) is the Finnish hattara in the sense of "foot cloth"; the patches of cloud envisaged in this explanation are not however connected with thunder as much as with autumn storms.

There is clearer information about Ukko's weapons. These included the hammer, the club, the thunderbolt or wedge, the bow and arrow, the nail, and sometimes the aze or sword. The thunderbolt or wedge 
are of stone, and so sometimes is the axe (stone axe from the sky, a magic formula from Satakunta), but the weapons are for the most part of metal (gold club; copper hammer). Ukonkivi ("thunderstone") is a widely used popular name for quartz. The name may be derived from the fact that pieces of quartz flare up if they are rubbed or struck together; a light may be distinguished, particularly in the dark. ${ }^{1}$

When lightning struck, the thunderbolt, wedge, nail or arrow was buried deep into the ground, where, in the course of time, it rose and could be seen. The thunderbolt was used to prevent "Ukko's fire", for which purpose - for example - it was placed on the roof joists, and with its help it was claimed that the fire caused by the thunder would die. Placed in the seed bag, it increased the harvest. It was also possible to grate a curative powder from it, to judge by the damaged stone blades in museum collections.

In the light of these arguments it may be stated of Agricola's Ukko that:

1. he corresponded to a thunder god known by this name throughout the country

2. he provided the weather, which in this case most probably means stormy weather, "god's weather", "the lord's weather"

3 . by giving the year's crops, he is equivalent to a growth-furthering thunder god

4. he promoted growth by union with a woman who is not directly mentioned in any other reliable tradition. The sexually explicit verbs used for lightning flashes may indicate an identification in this respect.

It should also be pointed out that according to Adam of Bremen the Scandinavian Thor was "master of the weather, he controlled the thunder and lightning, he ruled the wind and the rain, good weather and fertility", to quote Haavio's slightly free translation (Haavio 1959, 96). Ukko and Thor correspond so closely to each other that they must be one and the same god, and so it has been understood for centuries, as is apparent from the fact that Ukko is regularly translated into Swedish as Thor. Setälä (Setälä 1910) formed the same opinion on the basis of a similarity in names.

1 The author remembers how small boys in the 1930's often played by rubbing two pieces of quartz together in the dark, thus producing a bluish or greenish light. 


\section{The holy marriage}

Haavio's interpretation nevertheless requires further comment. Haavio is correct in my opinion to interpret the "huffing and puffing" of Ukko and his bride as a holy wedding to increase fertility. They are not however the fertility god and his mother, but they represent the "marriage" of earth and sky, in which sky represents the masculine and earth the feminine element. Haavio refers to the actual myth of the marriage of earth and sky, and also quotes lines placed by Aeschylus in the mouth of Aphrodite (Haavio 1959, 80, 96):

The noble Sky longs for the Earth and the Earth longs to marry the sky.

When the rain falls from the heavenly bridegroom, the earth grows fertile, the meadows bear for the flocks and Demeter's gifts to mortals.

The dew of marriage ripens the fruit of the trees. Therefore the credit is also mine.

Haavio nevertheless ignores the analogy offered by the myth with Agricola's Ukko, although it seems almost self-evident.

Against Haavio's interpretation it may be pointed out that in the myth of Sampsa one of the parties to the holy marriage is always a boy, or a young man. This feature is also fundamental in the Mediterranean sources of the same myth; in the latter, the young god or vegetation god wakes to life every spring: Adonis, Attis, Tammuz, as Haavio himself observes. The difference may perhaps be seen in the fact that Ukko makes the earth more fruitful, but Sampsa or Pellervo the fields. The fields were of course earth too, but earth also included clearings, meadows, pastures, forests, the whole basis of vegetation, and since the thunderstorm soaked them all without distinction, Ukko's fertility could not be limited to the fields. It is therefore another myth. Haavio is certainly right to suggest that ukko should be interpreted as an honorary title, which could be attached to other divinities, including Ilmarinen. But it does not seem to have been linked with Pellervoinen, Sampsa or the boy of the fields, for which reason $u k k o$ in the sense of "old man" cannot be eliminated in this context. Agricola's verses thus celebrate the holy marriage of the old man and his bride and not of the boy and his stepmother or mother, as in the myth of Pellervo or Sampsa. ${ }^{2}$

${ }^{2}$ On Sampsa see for example Harva 1948, 170-188; Valonen 1946; Kirkinen 1967. 
We may continue our discussion of interpretation by observing that the "Weather" which Ukko provides according to Agricola is certainly not "good weather" as Haavio supposed, but "dirty weather, rough weather, the storm", as Harva has established. Scholarship has long interpreted the "coming of the new" in accordance with Agricola's linguistic usage as "the coming of the year, harvest", and Haavio is of the same opinion.

Ukko is well suited as the giver of the harvest, however, because in the New Testament, too, Agricola presents the concept of the power of thunder to produce fertility, as Harva has verified. It is of no great importance, in my opinion, whether "the weather" and "the coming of the new" are interpreted as the gifts of Ukko, as has usually been the case, or whether they are the consequences of the divine marriage, as Haavio believed, since Ukko's activity could also be seen in this marriage. The word "Pohiasti" is difficult to explain. Haavio is on the right track in my opinion in suggesting that, written with a capital letter, the word refers to locality, Pohja, "bottom" or "depths". If this line of thought is acceptable, it cannot however be the "bottom of the field", as Haavio supposed, but more likely the "depths of the sky", the place where Pohjan tähti or Pole star was situated. This was where "Ukko, navel of the sky" lived (SKVR [= The old Finnic Runes] 7:4, 1594; Haavio 1961,13) and from there he could well puff greatly. It may therefore be affirmed that Agricola's description of the holy marriage fits the god of thunder and his bride at any rate, and that it fits them better than the boy of the field and his stepmother. There is no need to suspect, therefore, that Agricola's Ukko was not the god of thunder. If Haavio's interpretation were correct, it would have the remarkable consequence that there was no place for Ukko, "the highest lord", in either the Tavastian or the Karelian pantheons, although many lesser gods lived there. How could Agricola have failed to include the god whose violent power the ancient Finns must have feared most of all?

\section{Rauni}

Haavio, however, had the acute insight that Rauni may not have meant Ukko's bride, as four hundred years of scholarship has supposed, but Ukko himself, who would therefore be Rauni-Ukko. The hypothesis is quite possible, since Agricola does not appear to have used the hyphen. I have already pointed out that with this interpretation the problems 
of the enigmatical female Rauni disappear, including the fact that there is no mention of her elsewhere in reliable tradition. She may therefore never have existed! But not even Haavio himself feels he has discovered a convincing etymology for Rauni. He compares the name to the Old High German word fro, gen. sing. frono, "lord", and believes that Rauni may in some way contain the Germanic frauja, the equivalent of which in Gothic also meant "lord"; the word originally had an n-ending. The interpretation would certainly have been suitable in terms of meaning, but it is probably contrary to phonological history. According to Jorma Koivulehto, the auj sequence in protogermanic words, which does not appear in proto-Finnish, was replaced in the latter case by the sequence aiv as demonstrated by the protogermanic loan word "laiva" (ship) ${ }^{3}$; hence the au diphthong could not have been preserved at all. E. N. Setälä (Setälä 1912, 203 f.) offered the hypothesis that Rauni was derived from the same proto-word as the Swedish "rönn" (rowan, mountain ash), which would certainly conform to the laws of phonology, but it is contextually impossible, as Haavio points out; there are no connections between the mountain ash and the god of thunder, at least in the myths which have been preserved, to suggest that the mountain ash could be regarded as Ukko's bride (!) (Harva 1948, 128-136; Haavio 1959, 91 ff.). The etymologies proposed must therefore, as I understand it, be rejected. This does not, however, resolve the problem of Rauni, and neither does it eliminate the fundamental question: if Rauni is, as seems to be the case, an epithet for Ukko, why is it not linked with Ukko in other contexts?

The problem obviously belongs to the history of religion but, surprisingly enough, it also concerns archaeology and the humanities. If my proposal is correct, the question may be resolved by a return to antiquity. Zeus, the supreme deity of the Greeks, god of clouds, rain, thunder, promoter of vegetation and in these respects, therefore, a parallel divinity to Ukko is, on account of his numerous functions, the reciever of a large number of epithets, one of which is Keráunios. Keraunós means "thunderbolt, Donnerkeil" but also "lightning", whilst the adjective derived from it, "keráunios" means "belonging to the thunderbolt, struck by a thunderbolt, hurling thunderbolts" (Frisk

3 Frauja contains the sequence -auj, which was impossible in proto-Finnish and, according to Jorma Koivulehto, therefore replaced by -aiv-, as in the word laiva, whose proto-Germanic origin has been traced back to the form *flauja (Koivulehto 1973). Koivulehto's arguments are reinforced by the fact, too, that the Gauja river in Northern Latvia is in Livonian called the Koiva. 


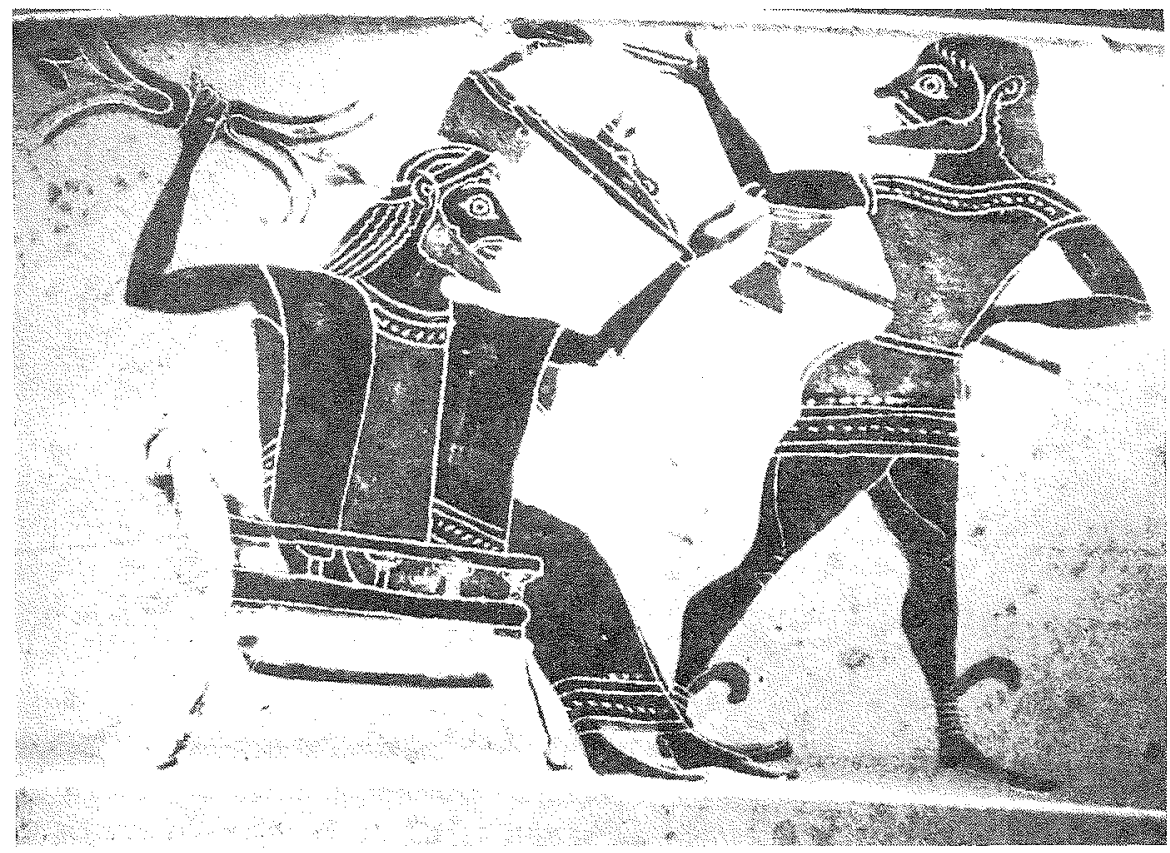

Fig. 11. Zeus on his throne giving birth to Pallas Athene and threatening Hefaistos with lightning in his right hand. The lightning is portrayed as a double-ended and multiforked arrow. Defending his act Hefaistos has struck Zeus on the skull to help the birth of Athene, who is armed with an aegis shield. Black-patterned vase from ca. 500 B.C. (Grant \& Hazel 1976.)

1960, 828), and apparently also "bearer of lightning". Keraunós is already mentioned in the Iliad, so it must go back to at least the eighth century B.C.

There is evidence of the worship of Zeus Keráunios (Fig. 11-13) throughout the Eastern and Central Mediterranean: from the Greek island s and mainland, from Cyprus, Asia Minor, Syria, Italy, Bulgaria (Schwabl 1972, 322 f.; Schwabl 1978). Both according to these authorities and on numerous vase decorations and statues, the attribute of Zeus was a winged bundle of lightning (Fig. 12), apparently borrowed from the East, where it occurs amongst other contexts as the weapon of the Canaanite Hadad-Baal (Schwabl 1978, 1018 f; Tatton-Brown 1984, fig. p. 88; Grant \& Hazel 1976, 421; Gray 1982, 51). Zeus's weapon was no longer in the sixth century depicted as a concrete weapon, as a thunderbolt, "Donnerkeil" (Fig. 11-14), but in Italy this concept nevertheless survived longer. In the temple of Jupiter, situated on 


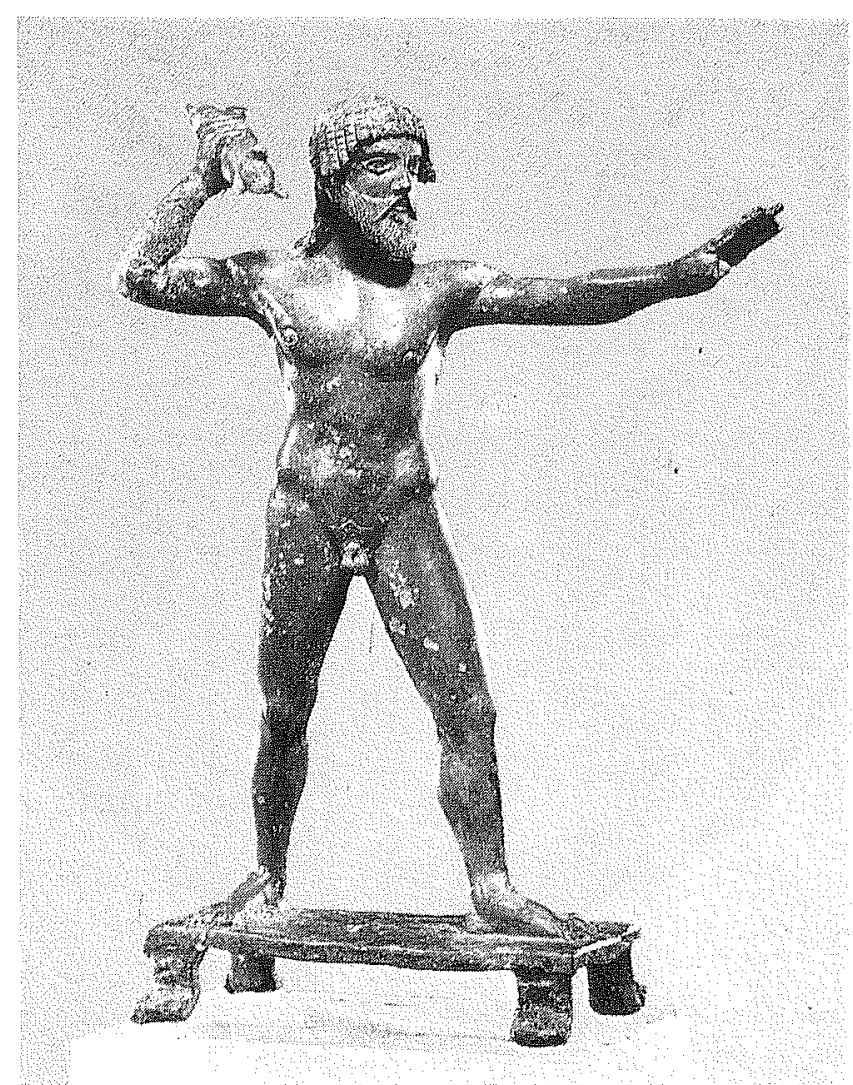

Fig. 12. Zeus Keraunios in the process of striking lightning. Bronze statue from the 5th century B.C. from Dodona. After B. Petrakos.

the Capitol and consecrated in 428 B.C., there has been preserved a flint stone, lapis silex, which has been interpreted as "an image of the thunderbolt" "ein Abbild des Donnerkeils"; according to this the name of the god was Iuppiter Lapis (Thulin 1917, $1128 \mathrm{f}$.). On the basis of this information, it seems that the notion of stone thunderbolts or undressed "thunderstones" was widespread in antiquity, at least from the beginning of the last pre-Christian millenium.

The corresponding Latin name borrowed from Greek, cerauniae, (thunderbolts) occurs, apparently spread by naturalists or humanists, in scientific literature from the 16 th and 17 th centuries. In Museum Wormianum, the catalogue of the collections of the famous Danish scholar, Ole Worm, they are described as follows: 


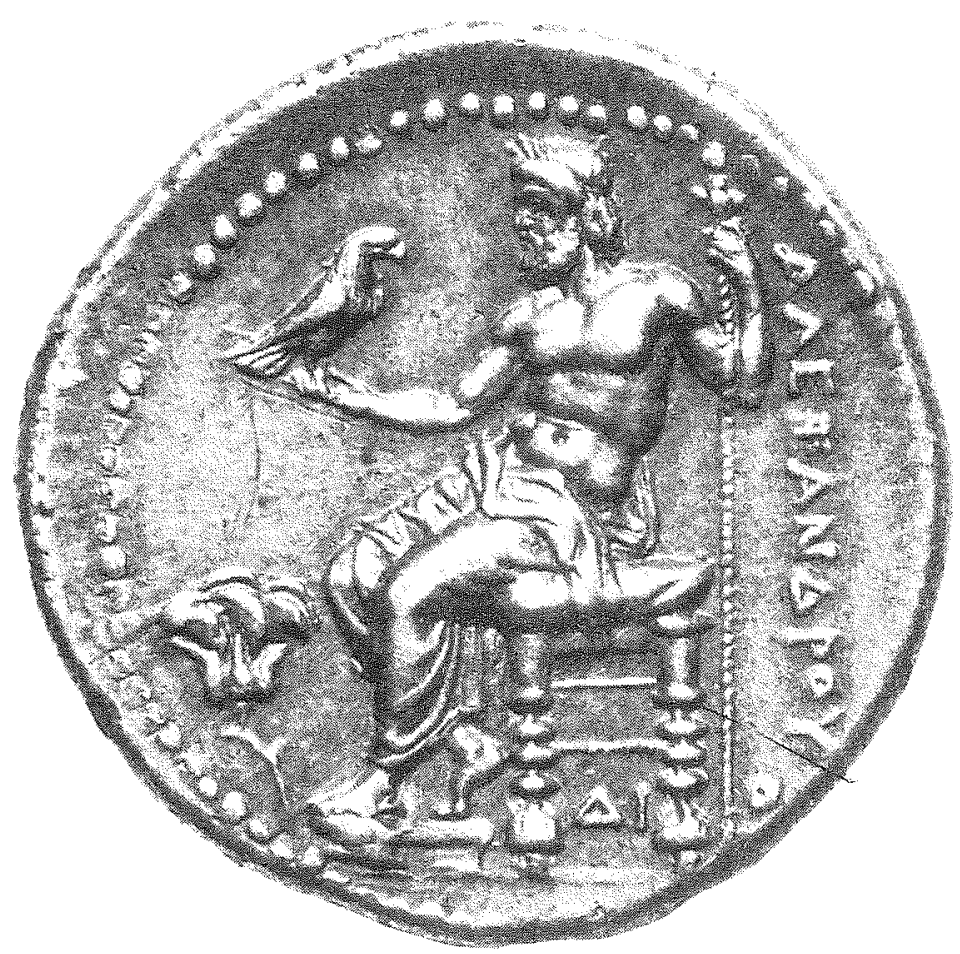

Fig. 13. Silver coin of Alexander the Great from the 4th century B.C. Zeus, the ruler of Olympus and Alexander's divine exemplar, is seated upon his throne with a sceptre in his left hand. Zeus also has attributes of the god of thunder in the illustration: in the lower lefthand corner there is a cloud from which a lightning-bird is emerging, and an eagle symbolising Zeus. (Grant \& Hazel 1976.)

"Cerauniae, so called because they are thought to fall to earth in the lightning flash. They have various shapes, sometimes conical, sometimes hammer- or axe-shaped, and with the hole in the middle" (Fig. 15). "Their origin is disputed; some deny that they are meteorites, supposing from their resemblance to iron tools that they are really such tools transformed into stones. On the other hand, reliable witnesses state that they have observed these stones on the precise spot - in a house or a tree, and so on - where lightning had struck" (Klindt-Jensen 1975, 23).

Worm's work appeared in 1655, but the term cerauniae was already current in mineralogical treatises from the previous century: Georgius Agricola, De Natura fossilium, 1546; Conrad Gesner, De Rerum Fossilium, 1565; to mention only a few examples (Rodden 1981). The 


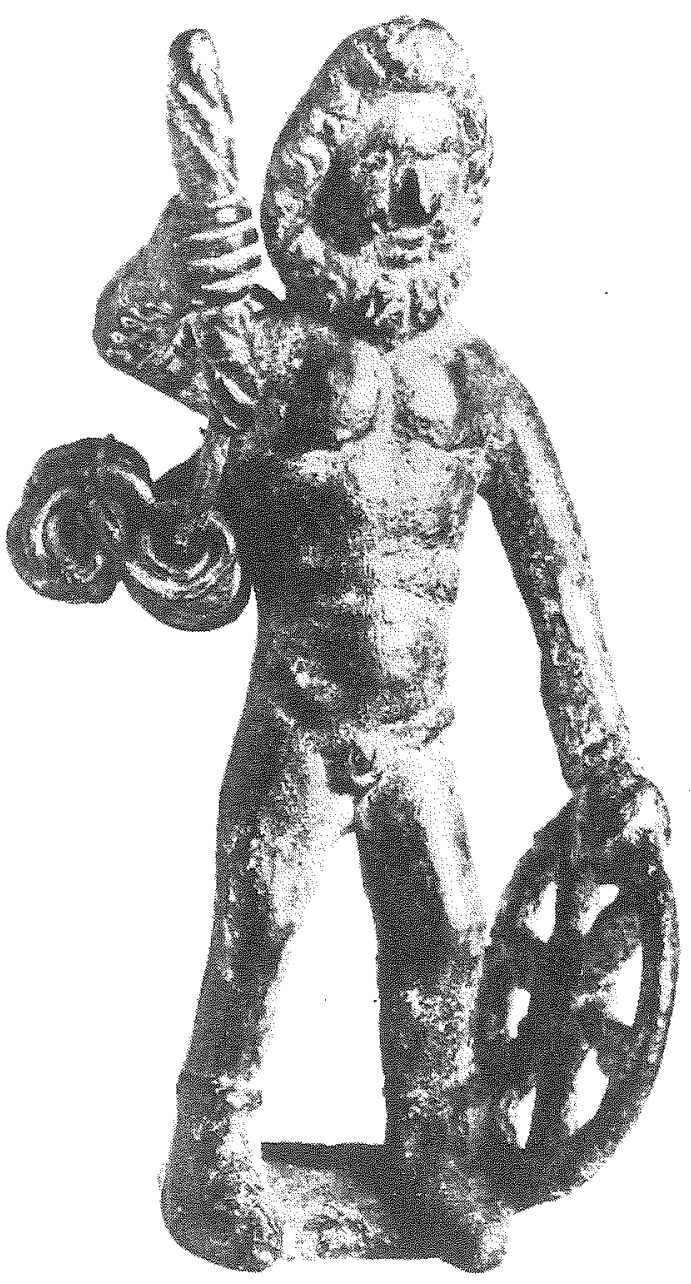

Fig. 14. Gallo-Romanic bronze image of Zeus from Châtelet, Haut-Marne. The lightning symbol of the picture has been borrowed from Zeus but the chariot wheel is from the Celtic god of thunder, Taranis. (MacCana 1970.)

word has, however, a much older history. In the form ceraunius it is found in the sources from the first half of the 13th century, and it can be still older (Almqvist 1956-78, 533 ff.).

The term ceraunium or ceraunia is a loan from Greek and seems to be uncommon in classic Latin. It is probable, that Agricola (1501?1557) did not came across it before the years $1536-1539$ at the Uni- 


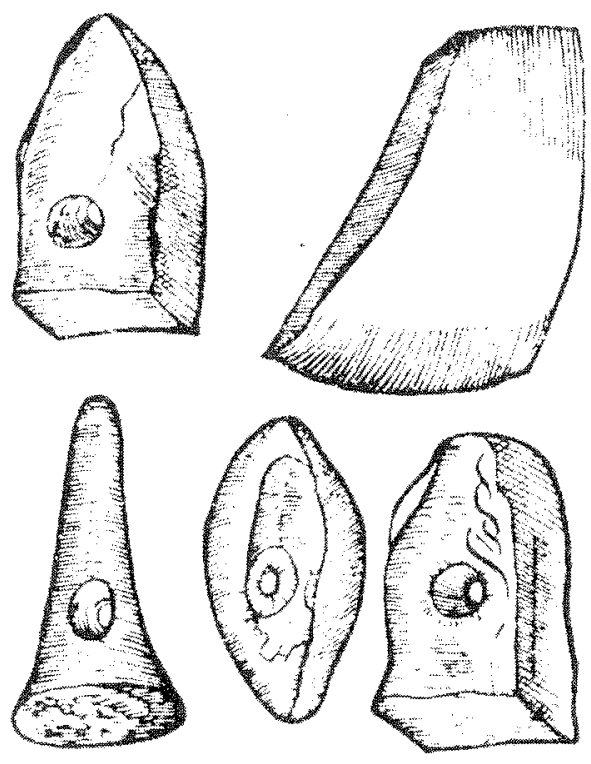

Fig. 15. Thunderbolts, cerauniae, found in Sweden. After a picture published by Ole Worm in 1655; the original picture dates back to the 16 th century.

versity of Wittenberg, though he understood Latin well ever since the schoolyears at Viipuri (Heininen 1976, 42-49, 56). At Wittenberg he, however, must have learned the term through the language of the humanists or naturalists. It may be mentioned, that Melanchton actually lectured during Agricola's first term on the second book of Ptolemy's De indiciis, which discusses, among other things, the causes of storms (Tarkiainen 1945, 120). The term must have been in common use, as Luther translated the Latin fulmen, 'lightning', as Donnerkeil, 'thunderbolt, ceraunia', in his German Bible (Donner 1966-81, 26). And at Wittenberg, at the latest, Agricola must also have become acquainted with the epithet keráunios for Zeus, when he acquired his real knowledge of Greek.

In Wittenberg at the latest, then, he would have confirmed the link between Ukko and Zeus, as well as the connection between cerauniae and thunderbolts, and accordingly given Ukko the epithet presumably derived from Latin - of Rauni. Rauni-Ukko would thus be Thunderbolt-Ukko or Lightning-Ukko. Agricola would have omitted the unstressed first syllable of the word ceraunia because the stressed second one was much more suitable for the first syllable of the Finnish form. He would also have omitted the last vowel of the word, presumably because words ending in $-i$ are common in Finnish, 
but - $i a$ endings are less frequent except derivatives.

According to this hypothesis, Rauni was Agricola's coinage, perhaps an impulse; the etymology, as such, is personal and "historical". It would suggest that Agricola equated the Finnish Ukko with the Greek Zeus, and there are no semantic problems involved. The etymology may also perhaps be phonologically acceptable. It would, in any case, explain why the word, Rauni, does not occur in other reliable sources connected with Ukko, and this absence would have to be explained in some way or another. Further support for a case of personal coinage is found in the fact that not even immediately succeeding generations borrowing from Agricola actually understood what he meant. It is still puzzling, however, that Agricola used an expression which was incomprehensible for most readers. Was the word used in Agricola's circles or did Homer nod?

Whether or not the etymology suggested above is correct, there is no doubt that the Finnish Ukko has Indo-European roots. Ukko is thus a migrant! We may therefore ask: are there any traces in archaeological material or in historical linguistics, on the basis of which the length of Ukko's residence in the Finnish sky may be more precisely calculated? Or is there anything enabling us to determine the phases of Ukko's existence? To answer these questions, I propose to examine the myths and attributes of Ukko, together with their archaeological interpretations.

\section{Ukko and Thor's hammers}

It goes without saying that Ukko dates from at least the Iron Age, the pre-Christian period. The case for this has sometimes been made by references to "Thor's hammers", which occur as pendants in finds from the Finnish Merovingian period (550-800), often fastened to men's large ornamental pins (Krohn 1914, 118; Harva 1948, 92 with suppl. ill. 96 f.; Kivikoski 1973, fig. 448, 480). They are anchor-shaped pendants in one piece or corresponding decorative pincers; Kivikoski assumes that the form is Estonian in origin. They are somewhat reminiscent of the Scandinavian Thor's hammers, but the similarity is, in my opinion, pure coincidence. The original objects are pincers which are becoming or have already become decorations, and the evolution of which leads to the pendant type of the Viking period, the so-called Karkku pendant (Fig. 16) (Kivikoski 1973, fig. 783). The latter is so far removed from the finds of the Merovingian period, 


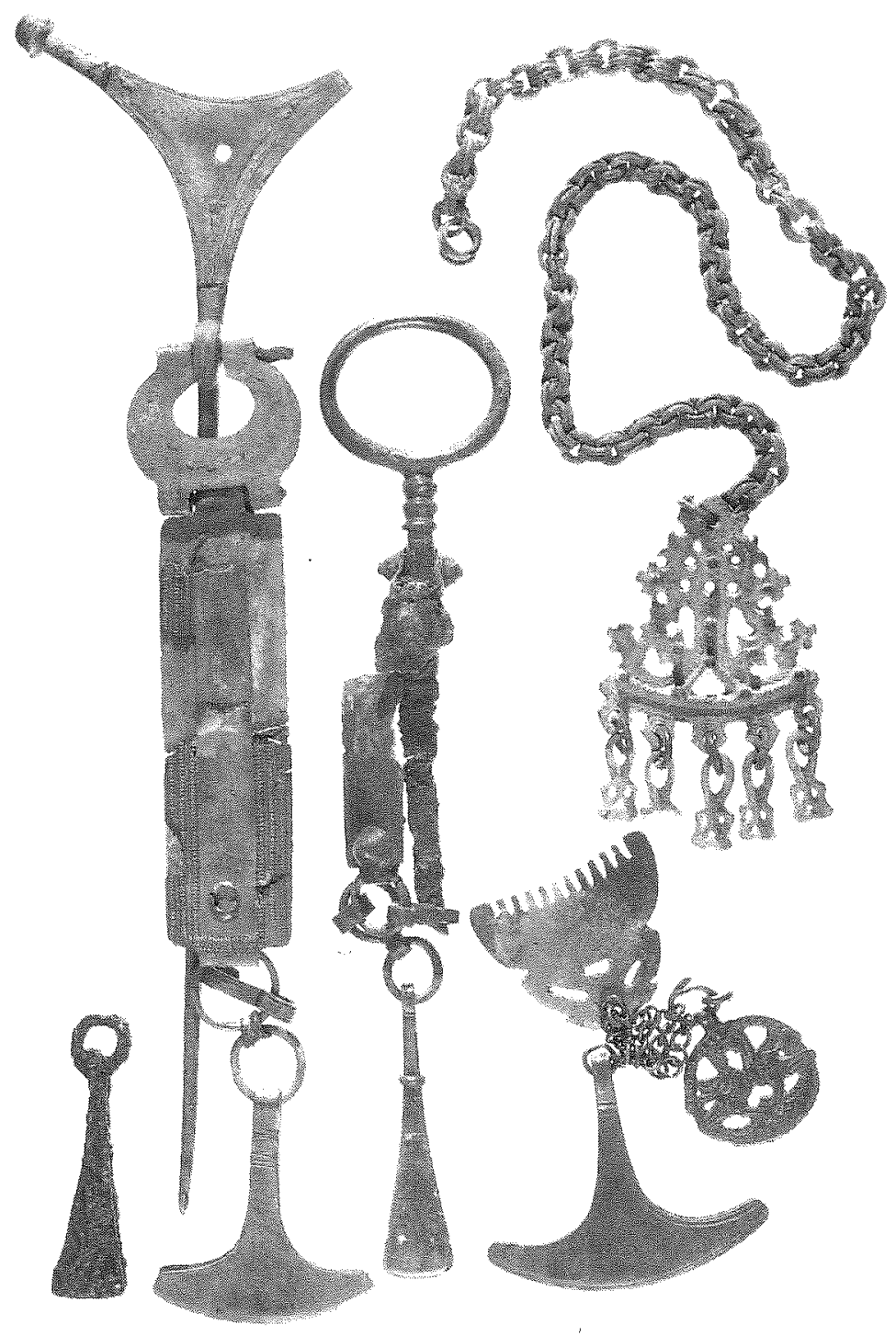

Fig. 16. Merovingian tweezers, "Thor's hammers" and a Viking pendant from the Finnish National Museum. On the left is a simple iron tweezer from Kansakoulumäki, Laitila; in the middle a similar bronze tweezer from Pappilanmäki, Eura, used as a decorative pendant; to the left of them tweezer broadened into a "Thor's hammer" in the "Kiikka needle"; in the lower righthand corner a massive "Thor's hammer" from the Papinsaari hoard, Kuhmoinen, and in the top righthand corner the Karkku pendant, the final stage of development of the "Thor's hammer". The development of tweezers from their simple iron form to anchor-formed "Thor's hammers" and lace-like pendants indicates that they had no symbolic content; otherwise the symbol would have had to be retained in recognisable form. National Museum, Helsinki. Photo: R. Bäckman, National Board of Antiquities. 
that an archaeological eye is needed to spot the connection. If the pincer pendants from the Merovingian period had been genuine Thor's hammers or the thunderbolts of Finnish popular tradition, their form would have been consciously preserved as clearly recognizable; they would not otherwise have functioned as amulets or symbols. For this reason, they probably cannot be linked with Thor or Ukko. Because of the typological evolution of the form, they cannot be interpreted either as the anchors popular in Christian symbolism; these objects and the comb-pendants (Kivikoski 1973, fig, 1984) reflect the transformation of utilitarian forms into decorative ones.

They would moreover be rather early examples of Thor's hammers: in Sweden and Norway the latter belong predominantly to the 10thcentury or to a slightly later period, when Christianity and its new symbols were also making the symbols of the old faith more relevant (Fig. 17) (Ström 1956-78, 503 ff.); it is true, however, that they are known from the end of the Vendel period. Finds on Alland from the Viking period include genuine Thor's hammers, small pendants attached to an iron collar (Kivikoski 1973, fig. 731 with explanations), but since they are Swedish in form and almost unknown on the Finnish mainland, they cannot provide any contemporary links with the Finnish god, Ukko.

\section{Ukko as the striker of fire}

More successful results may be obtained, in my opinion, from considering objects connected with the striking of fire. The first to examine these, together with ancient runes concerned with the birth of fire, was Jorma Leppäaho (Leppäaho 1949a) in his study "Fire Struck..." containing a number of useful observations on the subject. In some poems Väinämöinen is described as striking fire with a "sea stone", according to Leppäaho a marine stone or strange stone, a flint, which begins to appear as fire steel in burial finds from the Merovingian period. In the descriptions in ancient runes, according to which fire was born from the belt of Väinämöinen or the powerful stranger, even from the "three-part sheath", Leppäaho sees a reference to the splendid belts of the migration period, to which the fire steel was attached. Regarding these interpretations, I would like to point out that tinder was certainly carried at the belt - in the tinder-pouch - at other periods as well as the migratory one, and that some elliptical fire stones could be imported ones and thus also "sea stones". 


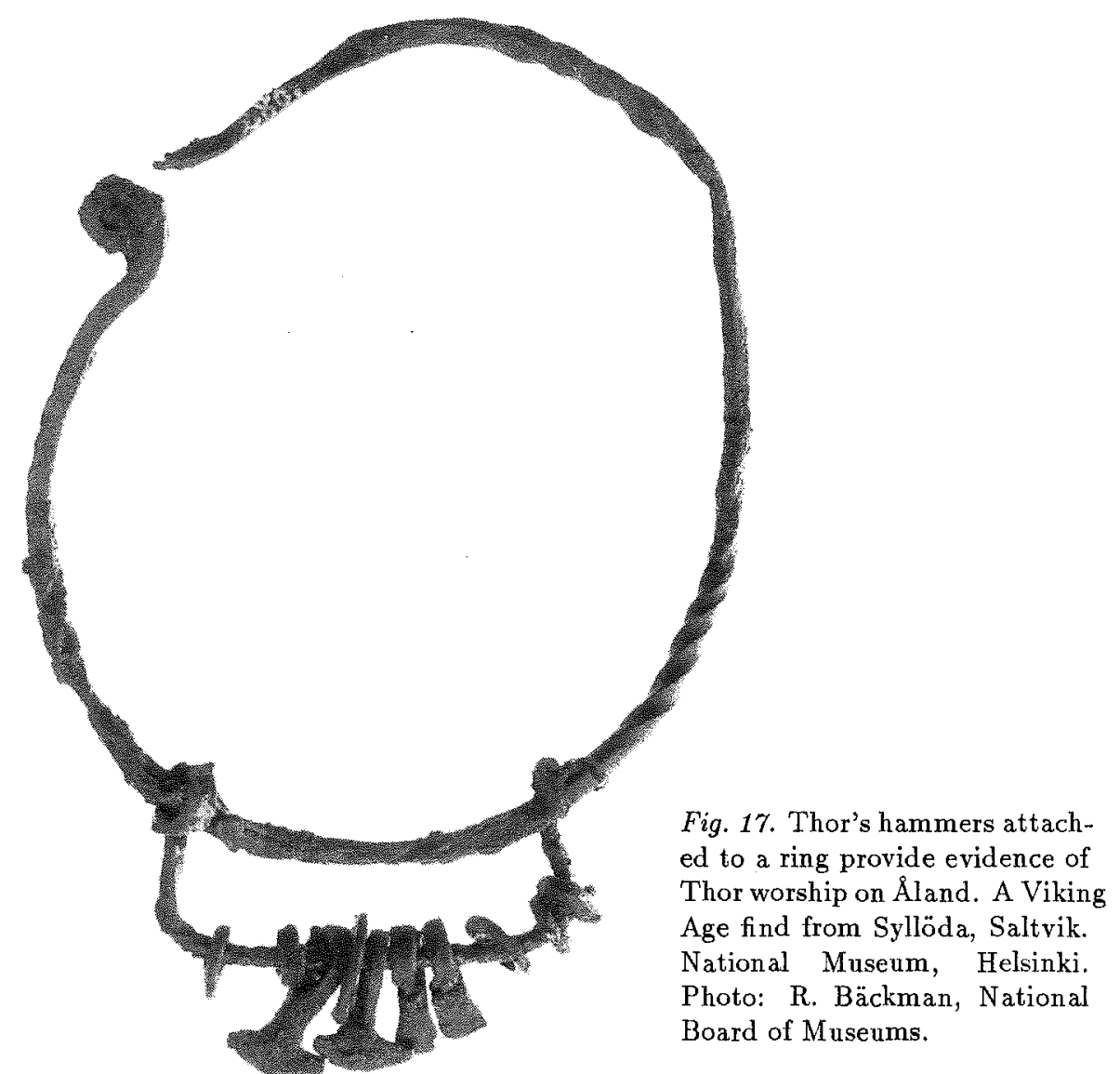

According to Krohn, the "three part case" was not moreover originally integral to the runes on the origin of fire (Krohn 1917, 94).

Inspired by these and other observations, Leppäaho believes that the poems on the mythical birth of fire include in their background many features of the actual making of fire, and that these have become poetically idealised. He is in a sense quite correct: runes and myths must have connections with the real world. In the present context, however, I would emphasize the opposite tendency: the real events of everyday life can also have reflected myths. This is very clearly the case with regard to the technique for the manufacture of fire: the fire-making implements of the Iron Age contain forms which could not be explained solely on the basis of technique, but they also reveal their mythical background. Leppäaho has recognized this in certain respects, but the argument could be developed much further. 
The point of departure must therefore be the mythical origin of fire: according to magic spells, fire comes from the sky or the air, either cradled at the centre of the heavens, or else released or born by striking; fire thus has two origins, which have nevertheless become confused with each other (Krohn 1917, 100-131). In this context we are only interested in fire created by striking, since the striker of the blow is referred to as the god of thunder, Pitkämöinen (Southern Ostrobothnia) and Ilman Ukko or Ukko of the Sky (Eastern Karelia), although together with Väinämöinen, Ilmarinen, old Ilmarinen, ilma(n)rinta (the bosom of the sky), ilmanranta (the edge of the sky), Ismaro; the three last-mentioned misinterpretations have been explained as referring to Ilmarinen. Whilst Väinämöinen is described as the striker of fire, often only in the refrain and therefore in a secondary role although not always, the original strikers of fire would appear to be Ukko and Ilmarinen. Without considering Ilmarinen at the present moment, I shall examine Ukko as an original striker of fire.

According to a poem from Russian Karelia:

Iski tulta Ilmanukko, Välähytti Väinämöinen

Kolmella kokon sulalla, Viijellä vivutsimella.
Ilmanukko struck the fire Väinämöinen flashed his lightning With three eagle feathers, With the five small rods.

According to Leppäaho's interpretation, fire is struck with an arrow, for the "three eagle feathers" refer to the plumes of arrows described in ancient runes and used by northern hunting peoples, including the Burjats (Fig. 18). More problematic are the "five rods" (in other runes, for example, "the rods of the sparrow"). Vipu may be translated as a "trap springing upwards" or "a handspike for lifting", but the word "vivusin" shows that it was not literally a question of a vipu or "rod", but rather of something "vivun kaltainen" or "rod-like". If "viisi" (five) is the correct attribute in this context - there can be no question here of a sparrow - it could then refer to the hand, to the five fingers needed for striking fire. But these are also needed for shooting a bow, and this is precisely what is meant: Ukko shot his arrows of lightning, from which fire was born; the bow does not seem to be mentioned as Väinämöinen's weapon, and for this reason he cannot be the chief archer. Leppäaho believed that terrestrial fire was struck by an irontipped arrow, which is quite possible, if the tip was made of steel. I regard it as more probable, however, that it was struck with an iron bow. 


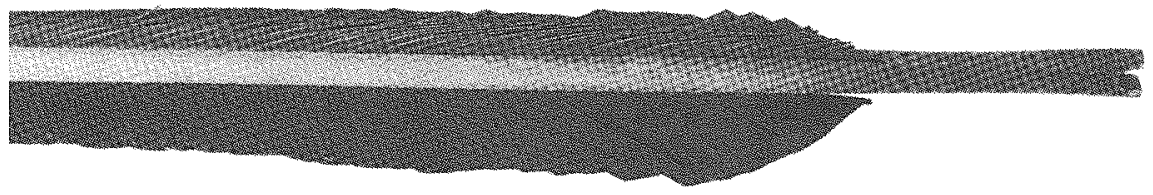

Fig. 18. A Buryat arrow with three eagle feathers. According to Jorma Leppäaho's interpretation reference in Finnish runes of how fire was first struck with "three eagle feathers" means that fire was struck from an elliptical fire stone using just such an arrow. National Museum, Helsinki. Photo: R. Bäckman, National Board of Antiquities.

This hypothesis is based on three bow-shaped fire steels, one of which was found at Gulldynt in Vörå, and the other at Mahlaistentönkkä in Vähänkyrö, all from the Merovingian period (Leppäaho 1949a, 81 f., fig. 11; Kivikoski 1973, fig. 643). They bring to mind combined or Asiatic bows, as is apparent from their curving points: the points of one, in fact, have actually been shaped into decorative spirals. Since the bow shape is a particularly awkward one for a fire steel, and is not justified by its function of striking fire - in the Merovingian period and above all afterwards fire was struck with more simple fire steels (Kivikoski 1973, fig. 642) - the only reasonable explanation is that the bow-shaped fire steel was a reference to the bow of the thunder god. Striking fire on earth may thus have been regarded as a repetition of fire struck in the sky, and to this end a miniature of Ukko's bow was sometimes used. On this basis, we may therefore date the notion of Ukko's bow and arrow to the Merovingian period, even if we cannot ascribe it exclusively to this era. From the point of dating of Ukko, himself, it is by no means a revolutionary hypothesis.

Bow-shaped fire-steels are nevertheless exceptional in Finland, although a process of simplification may be evident in two other fire steels from Gulldynt, three pieces from Luistari in Eura and one from Patraistenmäki in Laitila (Kivikoski 1973, fig. 644; LehtosaloHilander 1982, 72 f.) In these examples, string and bow have been combined in a solid plate, in which the points of the bow are clearly 


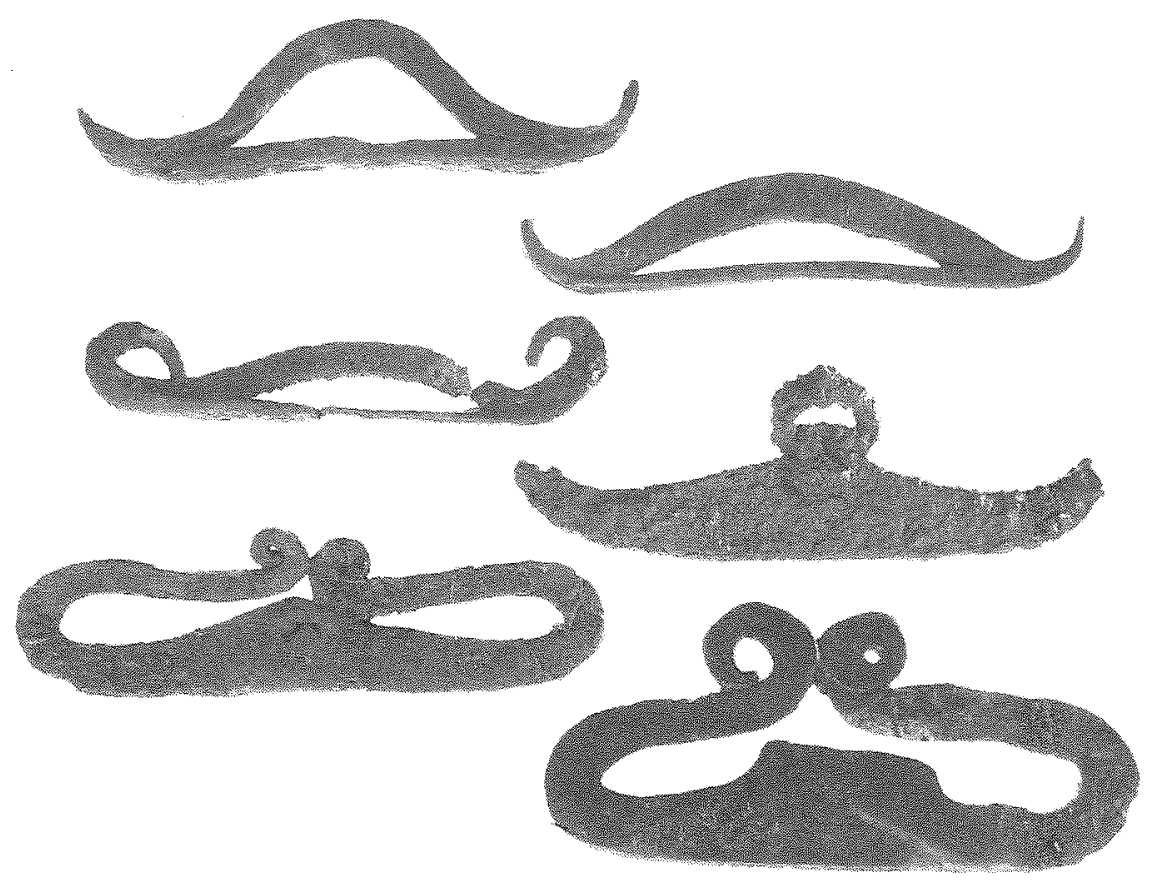

Fig. 19. Fire steels from western Finland. At the top bow-shaped fire steels from Mahlaistentönkkä, Vähäkyrö, from Patraistenvainio, Kalanti, and from Gulldynt, Vöyri. At centre right a looped "boat-shaped" fire steel from Gulldynt, Vöyri. At the bottom lyre-shaped fire steels from Kukkojenkivenmäki, Tampere, and Peltokutila, Kalvola. National Museum, Helsinki. Photo: R. Bäckman, National Board of Antiquities.

recognizable (Fig. 19). But bow-shaped fire steels were nonetheless far more common than these examples suggest. The so-called lyreshaped fire steels (Fig. 19) (Kivikoski 1973, fig. 641, 1008) may also be interpreted as bow-shaped, although the name of this type has prevented us from recognizing the connection with the bow-shaped form. In these examples, the points of the bow have in fact merely been bent forward onto the original arch from and stretched so far that the spiral ends almost touch each other. The bow shape has been distorted, but the central part of the combined bow can still be seen in a number of fire steels in the extension of the original curve; the latter detail is thus a rudiment which cannot be explained in terms of function, but only with reference to its original form. The lyre-shaped fire steels occur in finds from the Merovingian period, but become more widespread in the Viking Age (800-1050) and are 
actually preserved right into historical times. Judging by their wide currency, fire steels have been quite commonly linked with Ukko and the birth of fire.

It should however be added that these forms of fire steels are not exclusively Finnish, but were adopted together with the new technique for striking fire from continental Europe, either directly or through Scandinavia, where the use of fire steels also spread during the Merovingian or migratory period (Cleve 1943, $150 \mathrm{ff}$.); bow-shaped fire steels proper have also been found, for example, in Skåne (Scania), and closed bow-shaped fire steels in Skåne, Uppland, Norway and - apparently - in the British Isles (Strömberg 1981, 54; Lehtosalo-Hilander $1982,72 \mathrm{f}$.). If this interpretation of bow-shaped and lyre-shaped fire steels is correct, it cannot therefore be limited to Finland. I shall not go further into the subject at this point, but limit myself to offering an explanation for a Finnish myth; and perhaps, in this respect too, the god of thunder knew no ethnic frontiers.

\section{The evidence of fire stones}

Another object of examination is provided by elliptical fire stones. ${ }^{4}$ These are, as their name suggests, oval or tapering fire stones, generally $8-10 \mathrm{~cm}$ in length, with a gently curving, convex, front side, in the middle of which there is a longitudinal or slanting groove or doublegroove. The sides are convex in the oldest stones, in others more frequently hollowed out (Fig. 20); the hollow groove is explained by a band from which the stone was hung, probably from a belt; in Norway and Sweden, beautiful belts are known from the migratory period, and the fire stone was fastened tightly to these by means of a metal frame. Stones without grooves may have been carried in tinder pouches. With the exception of the very oldest finds or fortuitous, and poorly shaped forms, the elliptical fire stones are completely symmetrical in form and

4 Oval fire stones are considered in greater detail by e.g. Hackman 1905, $241 \mathrm{ff}$; Rydh 1917; Moora 1938, 569 ff. Other sources: Salmo 1957, 30 f.; Kivikoski 1961, 136 f.; Salo 1968, 169 f.; Huurre 1983, 132 ff.; Kostrzewski 1919, 178 f.; Kostrzewski 1955, 228 f.; Sjövold 1962, 187 f.; Okulicz 1973, 359 f.; Leube 1975, 33 f.; Tönisson $1982,291 \mathrm{f}$. - The boundary line of the oval fire stones in the map fig. 21 is drawn summarily. Great Russia, White Russia, Great Poland, Silesia, Elbe-Saale territory, and East Mecklenburg have been left outside of the area, in spite of some fire stones found there. I have information not enough to estimate, if some of these territories should be included to the proper area of the oval fire stones. Scotland and Ireland lay outside of the map. 


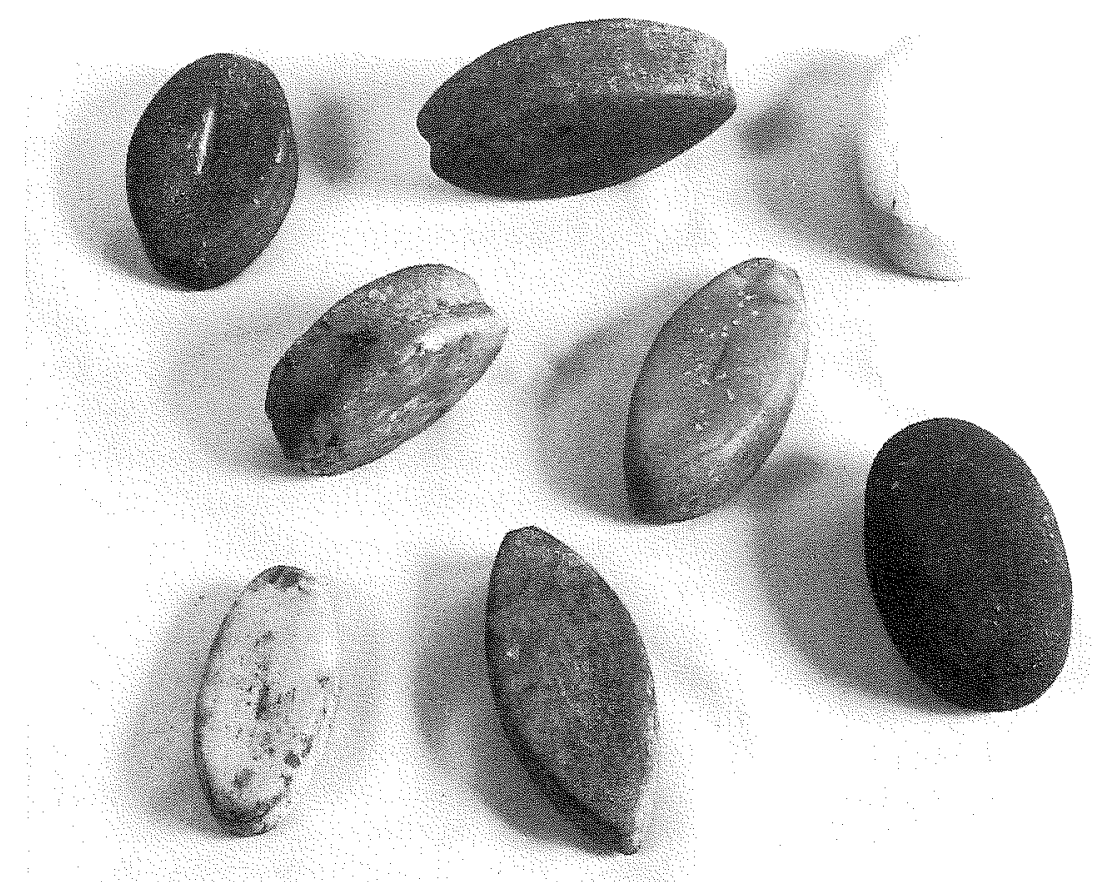

Fig. 20. Elliptical fire stones. The picture shows how carefully they were shaped and finished. Turku Provincial Museum.

both the front and back sides have been completely smoothed out. The sides are also usually smoothed, but sometimes in the grooves there are traces of chiselling; the whole design also requires chiselling technique, the traces of which have however been removed by careful polishing. The material is usually white or yellowish quartzite or sandstone containing quartzite.

By the beginning of the 1960's over four hundred elliptical fire stones had been discovered in Finland (Kivikoski 1961, 136 f.): They occur rather rarely in grave finds, and range in time from the early Roman period (50-200; the fire stones of Penttala at Nakkila and Parkkali at Pori) to the end of the Merovingian age, the 8th-century (the RintaUlvinen stone from Isokyrö). They appear to become more widespread in the later Roman period (200-400) and begin to give way in the Merovingian period to fire flints and fire steels (Cleve 1943, $150 \mathrm{ff}$.). Basically the same time limits are also found in Estonia, Latvia and 
Sweden, but some fire stones which occur in northern Poland date from the end of the pre-Roman era or from the beginning of the new calender; on the basis of this evidence, the type is assumed to have originated from the lower Vistula, from the region of Oksywie culture. From there it seems to have spread around the Baltic, to Sweden, Norway, Denmark, Finland, the Baltic countries themselves and Northern Germany (Fig. 21). Outside this area, elliptical fire stones only occur sporadically, with the exception of the British Isles, where the type was introduced by the Norwegian Vikings.

Elliptical fire stones were at first believed to be grinding stones, until it was shown that they were prepared from a kind of stone too hard for grinding, but suitable for striking fire; from these stones one can really strike a spark with a sharp piece of steel, even with the points of scissors, as Leppäaho has shown. In his study of fire stones (Leppäaho 1949a, $79 \mathrm{f}$.) he points out that in Finland no special fire steels were found together with the fire stones ${ }^{5}$; for striking, other edges may have been used, including the points of old knives, as described in one Southern Karelian verse fragment:

Iski Ilman ukko tulta

Välähdytti Väinämöinen

Veitsellä nykänenällä,

Kuraksella kultapäällä.

(SKVR 13:3, 8726)
Ukko in the sky struck fire Väinämöinen flashed his lightning With the blunted knife-point With the golden-headed knife.

Elliptical fire stones are nevertheless rare in grave finds; most of them are scattered finds and differ in this respect from other material from the Iron Age. This was noticed by scholars at an early stage and its significance has been discussed. I quote the carefully considered presentation of Alfred Hackman. After describing some of the elliptical fire stones found in graves, Hackman writes as follows:

"Alle anderen Steine, über deren Fundort wir nähere Kenntnis besitzen, sind Bodenfunde, zum Teil vielleicht Depot- oder auch Votivfunde. Die meisten derselben sind bei der Feldarbeit, auf Äckern und Wiesen, zum Vorschein gekommen. Dies gilt nicht nur von den Steinen, welche in der alten, an Altertumsfunden reicheren Kulturgegenden gefunden worden sind,

${ }^{5}$ Leppäaho has described the awl from the early Roman period found at Penttala in Nakkila on the assumption that awls were used to strike fire from oval fire stones. This suggestion may not be valid, as the oval fire stones, like the later fire steels, seem to occur only in men's graves, whilst awls were objects only found in women's graves (Salo 1968, 167 f.; Salo 1984a, 210 f.). 


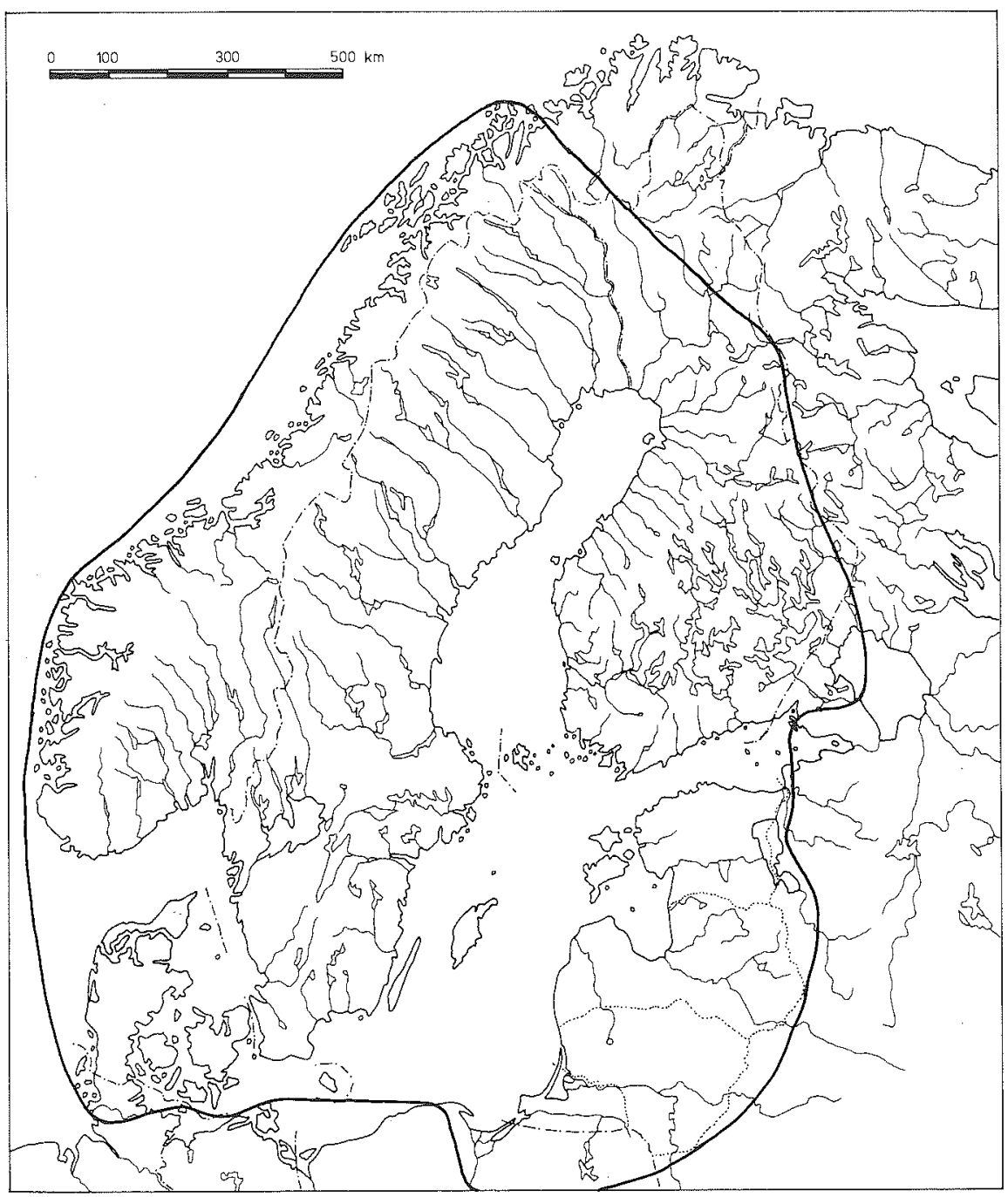

Fig. 21. Main distribution of elliptical fire stones. The striking of fire in this area was clearly understood in the centuries of the early Christian era to be a hieros gamos rite.

sondern auch von den Exemplaren aus abgelegenen Fundorten im Innern des Landes, an welchen weit und breit keine anderen Reste einer gleichzeitigen Ansiedlung angetroffen sind. Es sind daher selbverständlich nicht alle diese Äcker schon zur Zeit der weberschiffförmigen Steine bebaut gewesen. Von vielen derselben, und besonders von denen, welche ausdrüchlich als niedrig oder am Ufer eines Sees belegen zu bezeichnet werden, ist wohl anzunehmen, 
dass sie zu jener Zeit noch unter Wasser gestanden oder sumpfiges Terrain gebildet haben. Die an solchen Stellen gefundenen Steine wurden demnach unter dieselbe Kategorie gehören wie die nicht geringe $\mathrm{Zahl}$ derer, welche aus einem See, Sumpfe oder Flusse gehoben sind. [...] Da nach dem Zeugniss skandinavischer Funde Gegenstände, welche den Göttern geopfert werden sollten, oft in einem See oder Sumpfe versenkt worden sind, wäre es wohl denkbar, dass wenigstens einige der obengenannten weberschiffförmigen Steine Opfergaben dargestellt haben. Die Sorgfalt, welche auf die Herstellung der meisten dieser Geräte verwandt worden ist, sowie die Verbreitung derselben über weite Teile unsere Landes beweisen denn auch, dass ihr Wert in den Augen der damaligen Finnländer kein geringer gewesen sein kann" (Hackman 1905, 243).

There is no recent research on elliptical fire stones, but Hackman's description seems to be based on such extensive material, that it is still applicable today. Of over 230 fire stones known to him, ten are recorded as having been found in bogs, six in lakes, one in a river, and 17 on the banks of lakes or rivers; among the total number of fire stones this represents only about $15 \%$, but the figure is considerably higher if one only counts stones for whose discovery there is accurate information. ${ }^{6}$

Some oval fire stones are thought to have been dropped by hunters, because they have been found at great distances from the burial areas. This clearly indicates that the wilderness was used at the time as a region of extensive economy; the number of stones may, however, also include ones used by the Lapps. But it cannot merely be a question of stones that were dropped, for we should then have to assume that the stones were exceptionally liable to fall, which is however difficult to envisage. For this reason, Hackman may be right to suggest that they included sacrifices and votive offerings; most of them may be precisely this. The hypothesis is also reinforced by the shape of the oval stones.

Elliptical fire stones, as is well known, have a close enough resemblance to the female pudenda to suggest that they must have represented precisely this. The shape is without doubt intentional; the careful and laborious formation of the oval fire stone makes any other interpretation unlikely. It may be unnecessary to emphasize further that the shape cannot be explained satisfactorily by the technique for striking fire, so it must be related to the myths of this activity, to the atmospheric origin of fire. The point of comparison has already

\footnotetext{
${ }^{6}$ It should be mentioned that the fire stones found in the Tampere area were all water, shoreline or bog finds, in so far as the place of discovery is known.
} 
been made: "Whilst Rauni-Ukko's bride huffed, Ukko puffed greatly from the depths." The lightning flash is thus explained as a sexual act between heavenly and terrestrial deities, and correspondingly, the spark is produced by striking a vulva-shaped fire stone. It is difficult to interpret the shape of the fire stone in any other way; until now, there seems to have been no explanation at all. But if this interpretation is correct, it follows that an anthropological thunder god was worshipped in Finland during the period in which fire stones were used, ca. 100800. It also follows from this that the idea of the thunder god's influence on increasing fertility, as described by Agricola, would go back to this era. The interpretation is supported by the fact that fire stones were normally prepared from light-coloured quartzite, from a material which we not only refer to as quartz, but also as ukonkivi or "thunderstone".

\section{A fire stone community and religion}

Objects for making fire, both elliptical fire stones and the fire steels which succeeded them were, on the evidence of burial finds, exclusively or almost exclusively male objects. ${ }^{7}$ This may of course be due to the fact that men had to make fire in the open air, often far away, whilst the woman's task was normally limited to kindling the fire from the coal pile on the hearth, from the embers in which the fire was kept overnight and perhaps at intermediate periods during the day, by making air holes in the closed bag. The shape of the fire stone is also male in all its female symbolism. The bow-shaped fire-steels may also of course be characterized as male forms (Lehtosalo-Hilander $1982,72 \mathrm{f}$.). Does the adoption of these elements simply mean a change in the technique for striking fire, or does it contain at the same time a modification in notions about Ukko? Regarding the symbolic shapes of objects connected with the striking of fire, I assume that the technical change also had its mythical foundations.

We also find equivalent features in earthly fire-making in RussianKarelian runes about the origin of fire. According to these, the spark of fire, struck in the sky (Krohn 1917, 102):

\footnotetext{
7 At least the fire stones from Koskenhaka at Piikkiö (Kivikoski 1937, 38, fig. 21; Salo 1968, 62), from Parkkali at Pori (Salo 1970, 75 ff.) and Junnola at Sauvo (Salmo 1957, 30 f., fig. 18) are from men's graves or from combinations related to them. Oval fire stones are not found in women's graves.
} 
Tuo poltti pojalta polvet rikkoi rinnat tyttäreltä. or

Vaimo lastansa imetti alla reppänän retuisen. Rikkoi rinnat neitoselta, paloi parmahat emolta.
It burnt the boy's knees, broke the daughter's breasts. or The wife suckled her child Under the sooty shutter. It broke the maiden's breasts, burnt the mother's breasts alike.

These verses clearly reflect the heavenly origins of fire and the violent nature of the thunder god Ukko. Ukko was dangerous for a women sitting under the open shutter, with her breast bared; she might seduce Ukko into striking with his lightning (Salo 1990). The verses would appear to have a certain didactic or monitory flavour. According to a common folk tradition it was dangerous to sit by the window during a thunder storm.

The previous argument does not explain directly, however, why elliptical fire stones were sacrificed or otherwise concealed on the shores of lakes and rivers, or in bogs and meadows, even in shallow waters. In the first place it can, perhaps, be conceived, that by sacrificing an elliptical fire stone man begged for thundery weather, or most often, probably, only rain. A hunter required Ukko's help in catching wild reindeer, as for example in the following verses (Haavio 1961, $27 \mathrm{f}$.):

Ukkoinen, isä ylinen, mies on vanha taivahinen, ota kultainen kurikka hopiaisen orren päästä, komahuta konkeloa, säväytä säikälettä, pane luut lotajamaan, sääret säikälehtimään.
Ukkoinen, father above, old man of the sky, take the golden club from its silver perch, pound the bending tree, strike fear, make the bones tremble, make the legs move quickly.

Ukko was thus requested to frighten the prey into movement by means of lightning. The clearer of trees, on the other hand, needed rain, if the fire had broken loose in the forest, but rain was also necessary after planting if long droughts were threatening the harvest. Whatever the reason, however, I would suggest that by striking an elliptical fire stone, the hunter or clearer of forest was showing Ukko what was expected of him and why a sacrifice was being made to him.

As is clear from the above description, elliptical fire stones and both bow-formed and lyre-formed fire steels are forms borrowed from outside Finland. They may include examples brought here, although 
most of them were locally produced; the origin of every single fire steel has not been explained and it may be too problematical to attempt this. As I have already regarded them as reflecting Finnish myths of the creation of fire and, through them, the Finnish thunder deity, it might therefore be concluded that they are related to similar beliefs in other countries. To a certain extent, at least, this is true; the Swedish askpil and the Estonian Pikse nool, "thunder arrow", together with Perckun nohl (1660), "the devil's arrow", probably a late loan from Latvian, obviously also presuppose the thunder god's bow; thunder arrows are also known in Saami (Lappish) and Votian tradition (Krohn 1914, 118; Harva 1948, 88 f.).

\section{Ukko's cloak}

I observed above that Ukko has been characterised as wearing a blue cloak. Since viitta (cloak) is old Russian and thus a loan word from the Viking period at the earliest (Kalima 1952, 183), one might suppose that the feature in question is no older than this. It must be remembered, however, that among the emblems of the Mithraic cult the cloak of the sky god is recorded as early as the Roman period, and that in Scandinavia the cloak is a Bronze Age garment. It may also belong to the Bronze Age in Finland - we may recall the brooches and pins from the late Bronze Age, although there is not sufficient evidence about their use. The cloak nevertheless goes back to the early Roman period at least, as indicated by the brooches and pins found in men's graves. For reasons such as these, Ukko's cloak may be older than one might assume from the word itself.

\section{Ukko's nail}

By Ukon naula, "Ukko's nail", known in southern Häme and the eastern parts of Uusimaa, was meant a sharp-edged stone tool such as Ukon vaaja, "Ukko's wedge" or Ukon kynsi, "Ukko's (finger)nail" (Harva 1948, 88). Ukko's nail as a name for a tool of stone is strange since for the job of a nail, namely that of fastening, a stone edge is useless. Should, then, Ukko's nail be thought of as originally having been made of metal? A wooden nail would have been no good for striking lightning. Is there reason to doubt, furthermore, that nail did not originally indicate a "wooden plug or peg" as has usually been the case (SKES 369). The use of a wooden nail would of course 
necessitate the drilling of a hole, the earliest practice of which can be dated from Finnish finds to perhaps late Roman times or more certainly to the Merovingian age (Salno 1957, ill. 14; Kivikoski 1973, ill. 626). Since tools of the drill type were rarely placed in graves, it is of course possible to think that the drill was much older in Finland than finds indicate.

Nonetheless, it is obvious that a metal nail was much older than the drill. Early Bronze Age swords and daggers had their blade attached by means of metal rivets, as indicated by finds made in Finland (Fig. 22) (Meinander 1954b, tab. 3-5). Nails in imported weapons of the period date back to the beginning of the Bronze Age, to the latter half of the second millenium B.C. However, we have no knowledge of the use in this country of such old metal nails. This does not seem probable on philological grounds since naula, "nail" was clearly borrowed from Old Swedish naghle or, more likely, from its protoScandinavian predecessor; the proto-Germanic original, which can be dated to the Bronze Age, probably does not come into the question (SKES 369; Hellquist 1980, 688).

Iron nails, on the other hand, are common in Finnish finds from the early Roman period (50-150/175). They were used for fastening the hilts of sax swords, the bosses and handles of shields, spearheads and sometimes the blades of sickles (Salo 1968, illustration tables). It should be also noted that the nail of a spearhead (Fig. 22) found in the Malmsby hoard from Pernaja, which with good reason can be regarded as a collection of Finnish-made articles, dates from the end of the pre-Roman period, from approximately the beginnings of the Christian calendar (Salo 1968, 48:6; Salo 1984a, 191 f.). The history of the nail can thus be dated at the latest to the start of the Christian era. Adoption of the word naula, "nail", should probably also be dated to this period, not just because the adoption of a new name often occurs in conjunction with the appearance of a new article but also because the oldest iron nails made their appearance together with Germanic/Scandinavian types of shield bosses and spearheads. It should also be remembered that ancient verse fragments identified with the Merovingian period (Äyräpää 1925, 148 f.)

koira putkessa makasi, kasi naukui naulan tiessä.
The dog lay on the spear socket the cat whimpered in the nail's path.

indicate that what was used to fasten the spearhead was just a nail. It is therefore obvious that Ukon naula, "Ukko's nail", did not mean 

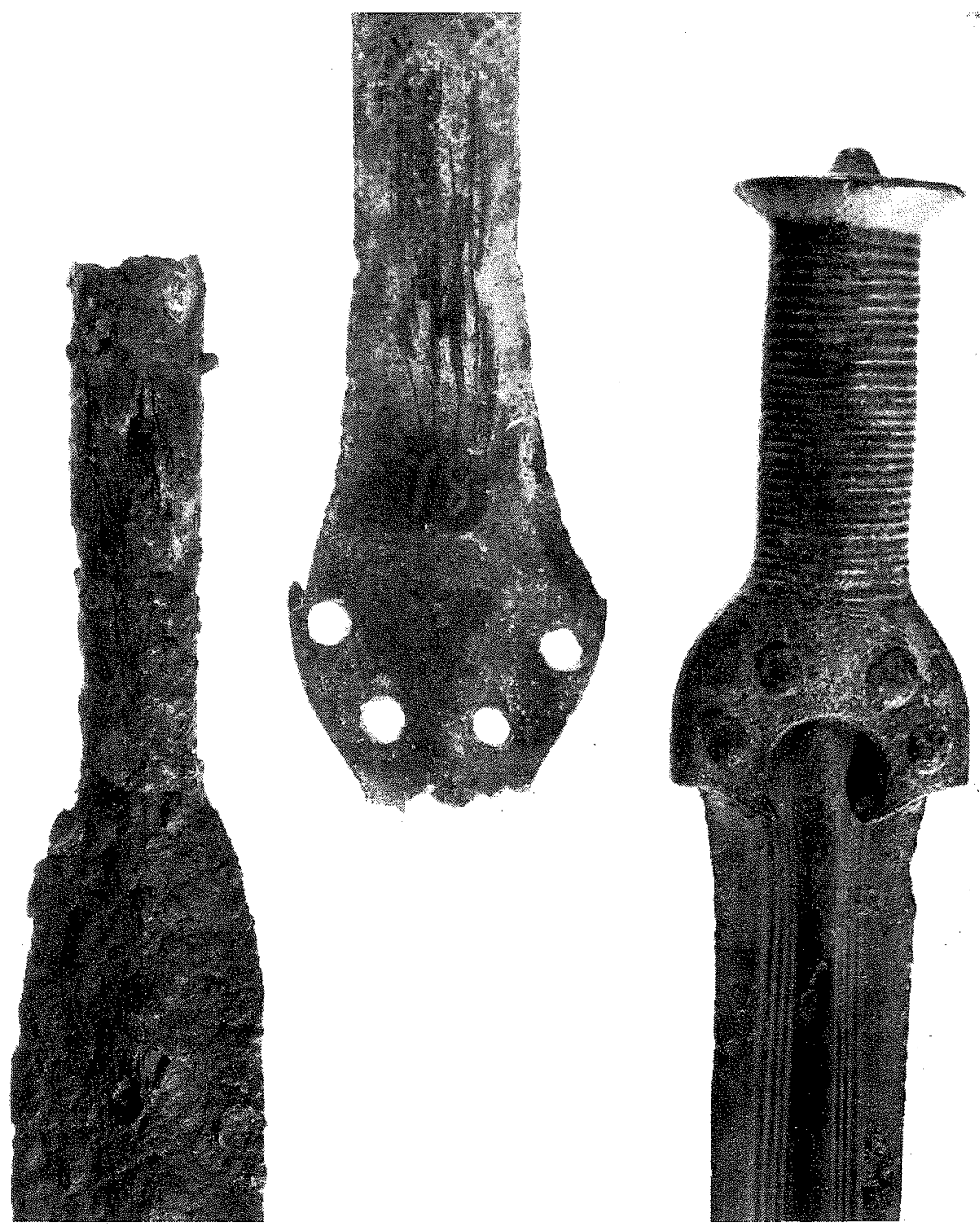

Fig. 22. Early nails and nail holes. On the left a Bronze Age II period (ca. 13001100) dagger from Långnäs, Dragsfjärd; in the centre a II-III period a tongue-shaft (?) sword from Kasaberget, Kirkkonummi; to the right a spearpoint fastened by means of an iron nail from Malmsby, Pernaja, from about the beginning of the Christian era. National Museum, Helsinki. Photo: R. Bäckman, National Board of Antiquities.

just any kind of iron fastener or rivet. Nonetheless, from the dating of the name we have in any case some kind of ultimate date for Ukko's nail, namely the iron nails that were first used from the end of the 
pre-Roman period onwards.

The thunderbolts of folk tradition are nevertheless linked with sharpedged stone tools; this, from the point of view of the nail's function, was noted as illogical. The explanation is possibly to be found in cultural or linguistic history. According to the Roman writer Pliny (23-79) it was possible to make a spark from a flint by striking it with a key, clavis, or another flint. According to Feldhaus clavis appears in only one manuscript; in others it is written clavus, "nail". This must be a spelling error since a nail is too soft to create a spark and also unsuitable by reason of its shape. Keys, on the other hand, would have been fine for striking fire since their handles could be made hard enough to strike a blow with them, as is shown by the keys found in the Roman fortress at Saalburg near Mainz; with these it is still possible to strike fire even today. Fire steels proper have been found only rarely in the Roman area (Feldhaus 1914, 319).

From this we are led to ask whether the Ukko's nail of Finnish tradition can be explained on the basis of a mistake made by Pliny's scribes. Since thunderbolts originated from the striking of celestial fire, could the well-known name for the fire-striking implement from Latin be applied to it, translated into Finnish by the learned Latinists, of course? This might well be possible and so the riddle of the naulathunderbolt would be solved. Ukko's nail was not, then, originally an attribute of Ukko?

There is, however, another explanation: alternative names for thunderbolt include not only thunder nail but also Ukon kynsi, "thunder", (finger)nail, and it is here perhaps that the explanation for thunder nail lies. Old Swedish naghle 'nail', referred to as the possible origin of the Finnish naula, is derived from the Old Swedish word naghl, naghle 'finger or toenail' (Hellquist 1980, 688). If the Finnish Ukon naula, "thunder nail" is a translation loan, then it may be a question of a misunderstood translation from the Old Swedish nagle. When ancient runes speak of Ukon kynsi, 'Ukko's stone fingernail', by which was understood stone 'thunderbolt' it is possible that Ukon naula, 'thunder nail', meaning the same, came about as the result of a mistranslation. Ukko with his fingernails of stone, in turn, refers to the god of thunder in the form of a bird, which is discussed below. 


\section{The thunderbolt and Ukko's hammer}

More important attributes of Ukko, however, are the thunderbolt and the hammer, and perhaps also the club. Thunderbolts in Finland, as is well known, refer to stone bolts. Equivalents to this term are known in the Germanic languages, as for example the Swedish askkil and the German Donnerkeil (Harva 1948, 99; Vries 1956--57, 2, 125). Since they correspond to the Greek keraunos, "lightning, thunderbolt", which already appears in the Iliad, it might be a question of an early loan from the culture of antiquity. It is most probable, however, that it contains an original feature of the Indo-European thunder god, a reminder that his weapon was made of stone.

Such a concept could also be applied to stone chisels found on the ground after a period when they were no longer recognizable as having been made by man; in Finland this did not perhaps happen before iron began to be used, since stone blades for work purposes were manufactured to some extent at the end of the Bronze Age, as was the case in Baltic countries, too (Salo 1981, 96 ff., 284 f.; Graudonis 1967, tab. II). Because of their wedge-shaped form they may be described as thunderbolts, perhaps after Scandinavian models, especially chisels; they also form the majority of polished blades from the Stone Age and are common finds in Finland.

Only when, after the transition from the Bronze to the Iron Age, shaft-hole axes were no longer made, and their original significance was forgotten, could the stone chisels be explained as wedges to replace them. From this, we assume that the thunderbolts in this sense are no older than the Iron Age. They thus go back, at the earliest, to a preRoman period, but perhaps only to the beginning of the new calender. They are known from graves of the Iron Age, but most of them are apparently fortuitous finds, brought to the graves of the culture layer and thus, in this respect, without significance. It may be affirmed, on the other hand, that the name ukonvaaja (thunderbolt) is evidently a translation loan from the Swedish asskkil or - less probably - the German Donnerkeil, so we are perhaps dealing with a loan from the west of an attribute particularly suitable for Ukko. As such, it cannot of course be precisely dated on the basis of Finnish material, but since the same principles for dating are valid for Scandinavia as well, the stage between the Bronze Age and the pre-Roman period may there, too, be the terminus post quem for the thunderbolt. At the same time, it is also the terminus post quem for the translation loan in question.

An older attribute than the stone thunderbolt was without doubt 


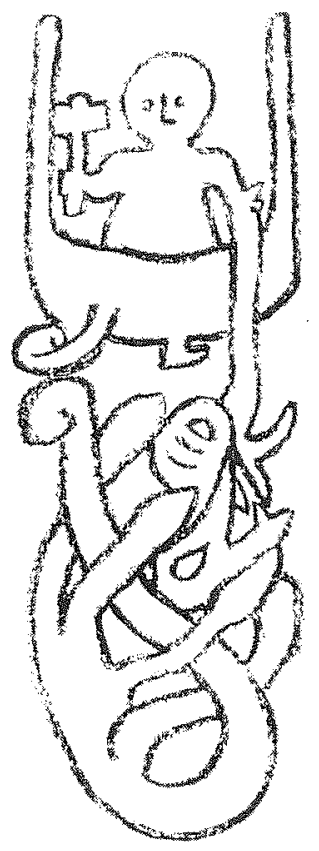

Fig. 23. Thor, holding his hammer Mjölnir in his hand, fighting the Midgard serpent. After $\AA$. Ohlmarks. Runestone drawing, Altuna church, Uppland, Sweden. (Ohlmarks 1975).

the stone shaft-hole axe or hammer. From these are derived the Scandinavian Thor's hammer (Fig. 23), Mjölnir, and the vajra of the Hindu Indra; Indra is known as hammer hand, vajrapani. The axe or hammer of the Lithuanian Perkunas is of the same origin, as is the hammer of Sucellus among the Celts or the hammer of the Saami Horagalles (Harva 1948, 92; Vries 1956-57, 2, 124 ff.; Haavio 1961, 30-36; Moreau 1958, $106 \mathrm{f}$.). On the other hand, the double-bladed axe placed in the hand of the Danubian Jupiter Dolichenus may have a different origin to that of the actual god (Harva 1948, 92 or $96 \mathrm{f}$.).

\section{The history of battle axes}

The battle axe with a hole, a weapon with a stone blade at one end and a long hammer at the other, is one of the leading types of the thousand year funnel-beaker culture (3300-2500/2300?); this culture extends westwards almost to the mouth of the Rhine, eastwards over the Vistula, southwards to Bohemia and the upper reaches of the Vistula, and northwards to Skåne, Sweden (Becker 1969, 1486 ff.; Jazdzewski 
1965, 83-89). The first battle axes appeared in Danish finds at an early phase of the funnel-beaker culture (Jensen 1982, 118), according to uncalibrated dating perhaps from the end of the fourth millenium. ${ }^{8}$ Their true period, however, dates from the beginning of the third millenium. It is then that the widespread funnel-beaker culture in Central Europe, Denmark and Southern parts of Sweden produces many-edged hammeraxes (Fig. 24, 25) (Stenberger 1964, 64 f.; Brøndsted 1938-39, 1, $155 \mathrm{ff}$.); much later, i.e. ca. 1500-1200 B.C., hammeraxes of same shape also spread to the Central Volga and the Caucasus (Tallgren 1926, $114 \mathrm{ff}$., $131 \mathrm{f}$., fig. 48 and 68,6) during the second phase of the Bronze Age, according to Scandinavian chronology. Hammeraxes cannot be explained without assuming metal models. According to general opinion, they are an imitation of copper axes of a type known, for example, in Hungary; from there, one example seems to have reached as far as Skåne (Fig. 24) (Stenberger 1964, 64 f.).

Battle axes were even more widely disseminated by the cord-ceramic or battle axe culture in the middle and at the end of the third millenia (according to uncalibrated chronology). From that period, characteristic boat-shaped axes or other forms (Fig. 27) are known from the Rhine to the Volga and the Dneiper, and from North of the Danube to Sweden, Norway, the Baltic countries and Finland (Fig. 26) (Buchvaldek 1969). In these objects one may readily observe signs of metal technique, although it has not been possible to demonstrate direct metal models; neither has it been possible to show that analogous Caucasian copper axes, known at least from the cord-ceramic graves of Dneiper-Desna and from Eastern Russia, are older than the stone ones (Sulimirski 1970, 190 ff.; Ailio 1909, 1, fig. 30). Battle axes, according to received opinion, were weapons and where graves are concerned, occur exclusively in finds from men's graves. Judging by

8 In datings of the Finnish Stone Age, according to Ari Siiriäinen's chronology, uncalibrated values are used for $\mathrm{C} 14$ datings; in these, C14 datings have not been checked according to calibrated revised curves, and for this reason, uncalibrated values have also been used for Scandinavia and Central Europe. As an example of this, it may be pointed out that the beginning of the Swedish Bronze Age pushed back from the previously used estimate of ca. 1550 B.C. to a calibrated value of ca. 1800 B.C. The mid-neolithic period corresponding to the battle axe culture is similarly pushed back from ca. 2600 to 3300 . Time estimates for Swedish cultures cannot be accurately transplanted to Finnish culture periods; it may be noted, for example, that the Finnish Bronze Age is not regarded as having begun until the latter half of the second phase of the Scandinavian Bronze culture, perhaps around 1400/1300. On the chronology of the Finnish Stone Age, see Sirriäinen 1969; Siiriäinen 1972; Sïriäinen 1973. 

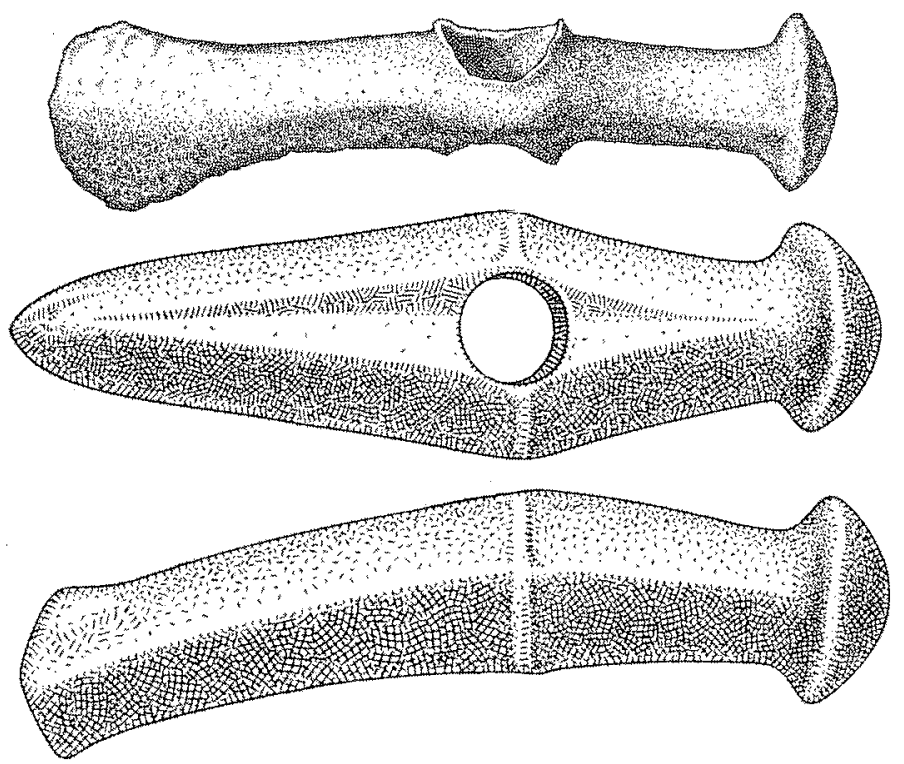

Fig. 24. Above a southeast European (?) copper axe, probably found in Skåne, Sweden; below a battle axe reminiscent of copper axe models from Södermanland. The axes date back or probably date back to the beginning of the 3rd millenium. (Stenberger 1964).

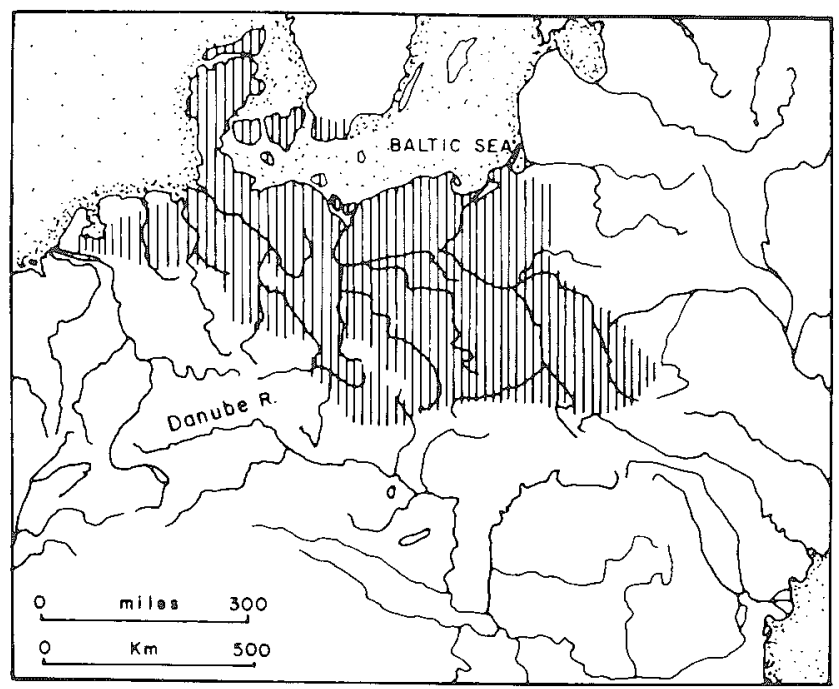

Fig. 25. Map showing extent of Funnel Beaker culture. (Milisauskas 1973). 


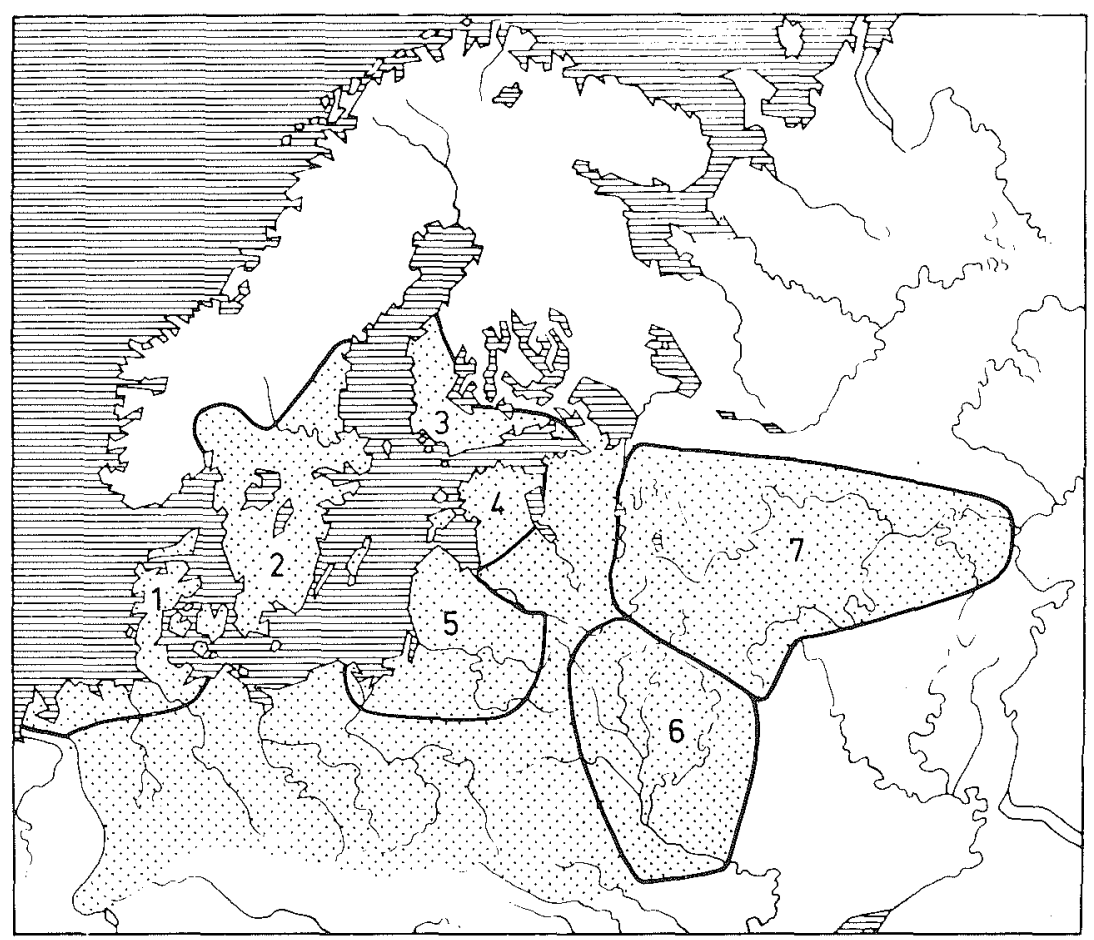

Fig. 26. The distribution of Corded Ware (Battle axe) culture. (Jaanits 1957).

their careful design and finishing, they also revealed the social status of the bearer. The nature of the culture itself is characterized by the fact that the leading types were men's weapons; there are no equivalent leading forms among the special objects of women.

The manufacture of stone shaft-hole axes remained extensive in the cord-ceramic area until the late Stone Age and the Bronze Age, i.e. long into the period succeeding the battle axe culture; the term shafthole axe implies that the axes often lacked a separate and distinctive hammer. Shaft-hole axes are widely known from the Bronze Age in the Scandinavian countries, in Holland, the Northern and Central parts of Germany, Poland, Eastern Prussia, the Baltic countries and Finland (Fig. 28) (Glob 1938, 62; Kostrzewska 1953, 239-254; Meinander 1954a, 76-85; Meinander 1954b, 67-84; Stenberger 1964, 132 ff.; Baudou 1960, 47 ff.; Graudonis 1967, 82 ff., 149; Löugas 1982, $132 \mathrm{ff}$.). The majority of these belong to the late Bronze Age, and the circumstances of some of the finds (Denmark, Poland, Latvia) point towards the pre-Roman period. The use of battle axes and other 
shaft-hole axes which succeeded them thus continues from the end of the fourth millenium until ca. 500/400 B.C. In addition to stone ones shaft-hole axes were manufactured in many areas from copper and bronze, too. These are in part like the simple stone forms, but more often decorative, provided for example with embossed or flattened hammers. They obviously include weapons, but at least some of them were manufactured for cultic use, judging from the great size, the weight, the shape or the slimness (e.g. Stenberger 1964, 173, 189, $193 \mathrm{f}, 201,286 \mathrm{f}$.).

\section{Shaft-hole axes in Finland}

The battle axes and the other shaft-hole axes spread to Finland, too. A Scandinavian many-edged hammer axe was discovered at the Hämeenniemi settlement at Lapua, which dates from the end of the combceramic period proper to the beginning of the late comb-ceramic time, i.e. 3000-2600 B.C. (Äyräpää 1955; Siiriäinen 1972, 15 f.); it is among the oldest of Scandinavian objects introduced to Finland. An Eastern Russian hammer axe found at Kemijärvi may be dated to the latter half of the second millenium and thus seems to be at least a thousand years younger than the previous example (Huurre 1983, $198 \mathrm{f}$.).

Hammer axes like these are nevertheless exceptional in Finland, but all the greater historical importance attaches to the Finnish boatshaped battle axes, since some 900 examples of them are known up to the present time (Fig. 27) (Edgren 1984a, 78). They brought to Finland a battle axe culture which spread south and west of a line formed by the Gulf of Viborg-Lahti-Tampere-Kokkola (2500-2000)

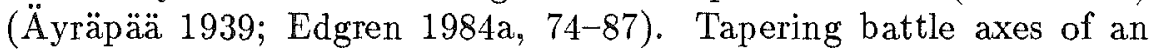
Estonian type and the flatter axes which evolved from them, together with Scandinavian forms, were also manufactured after this, during the Kiukais-culture (2000-1400/1200) (Soikkeli 1912; Meinander 1954a, 76-85). Scandinavian and southern shaft-hole axes were also imported and manufactured later, at least until the end of the Bronze Age (Fig. 28) (Meinander 1954b, 66-84). Shaft-hole axes of stone were thus used in Finland for a couple of thousand years. 
Fig. 27. Battleaxes from the Satakunta $\mathrm{Mu}-$ seum collection. Second from top the continental I-type; below it a Finnish II-type axe. Satakunta Museum.
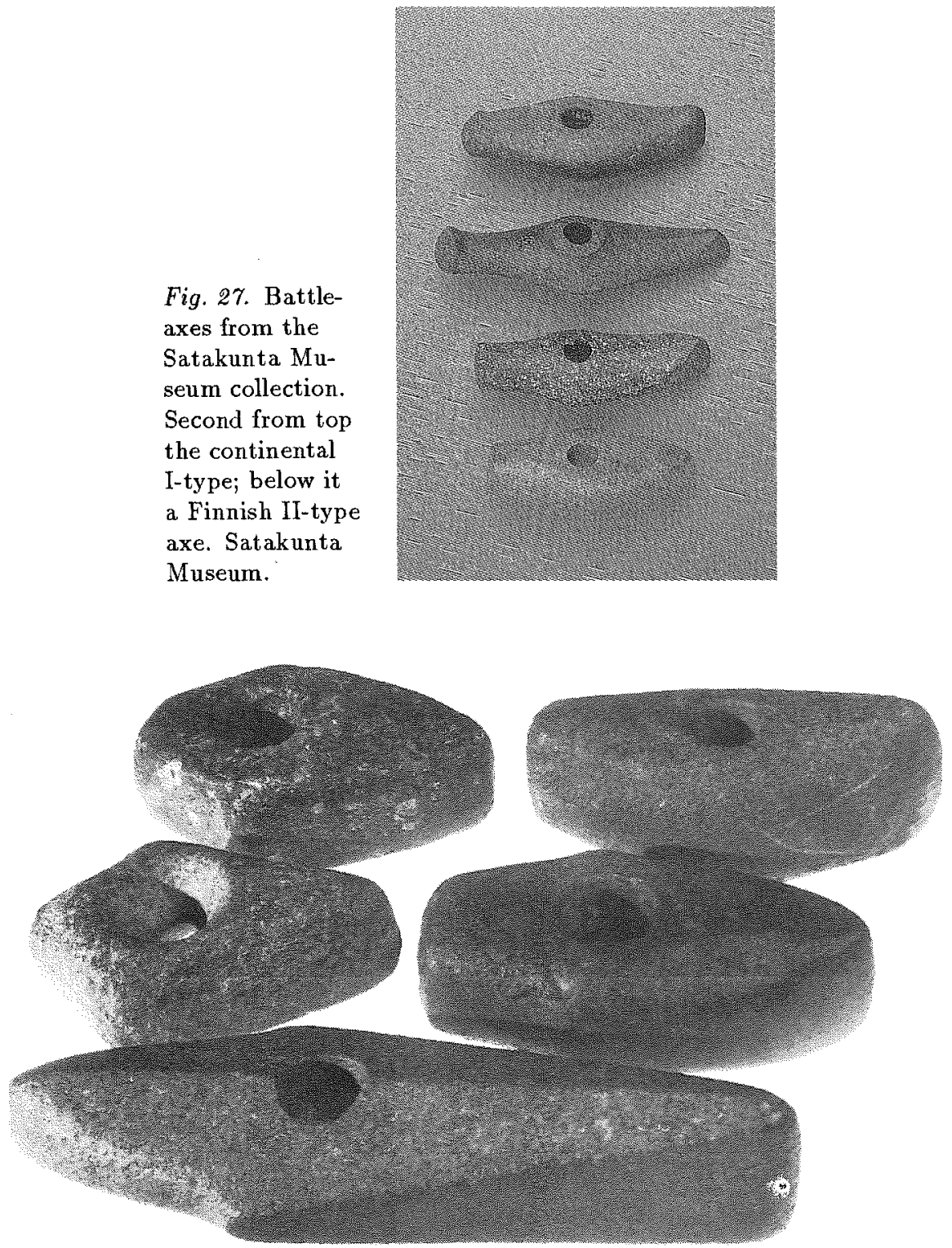

Fig. 28. Bronze Age shaft-hole axes. Top left a five-sided axe from Harjavalta; the others are Scandinavian rhomb-shaped axes from Jepua, Kodisjoki, Peräseinäjoki and Närpiö. The last of these is almost certainly an import but the Kodisjoki axe is a poor imitation of a Scandinavian axe as can be seen from the hole made in it. National Museum, Helsinki. Photo: R. Bäckman, National Board of Antiquities. 


\section{The sky god, the mother goddess and human society}

The Ukko of the ancient Finns was thus the god of thunder, but at the same time a general deity, the sky god, "at the navel of the sky". Ukko the general deity is regarded, probably with some justification, as having been influenced by Christianity. The matter, however, is by no means self-evident, as the Scandinavian Thor was also more a general deity than a god of thunder during the Viking period - at least in myths - although his divinity with regard to thunder flourishes in popular belief as a kind of subflora in the garden of myth. It may of course be observed in this context that Thor's nature, too, could have been formed under the influence of Christianity, but philological evidence nevertheless suggests that the concept of the overall god was far older, and went right back to the proto-Indo-European period. The Indo-European tradition included the notion of a male deity, regarded as father, giver of light and the day, and - to some extent - as a general deity, although not the creator of the world (Schwabl 1978, $1010 \mathrm{ff}$.; Wachsmuth 1964-75, $1516 \mathrm{ff}$.). Evidence for this may be found in the southern names for the gods of the sky, i.e. Zeus, "day, heaven", Jupiter, "father heaven", and the dyauh of the Veda scriptures, all of which are of proto-Indo-European origin. Equally old, or perhaps older, is the sky god's consort and fertility goddess, Ukko's wife, Demeter, Ceres and Siv, although this idea cannot be established on the basis of similarities in names.

The heavenly couple, in which the sky god/thunder god was clearly dominant, reflects a common conception of human society with a patriarchal family structure. Early neolithic communities in Southern and South Eastern Europe, however, have been and still are interpreted as matriarchal. In this context, reference is made both to the prevalence of matriarchy in primitive agricultural societies, and to the sexually explicit female figures, idols known from the Balkans and other parts of South-Eastern Europe from the fifth millenium onwards (Filip 1969, 754). Similar concepts are suggested by the Minoan figures of goddesses dating from the first half of the second millenium, particularly when corresponding figures of male gods do not occur. No images of mother goddesses are known, however, from the neolithic cultures of Central Europe and Scandinavia (Nuñez 1986, 17), for which reason the worship of the Magna Mater may not have been so dominant there. The areas north of the Danube would thus seem to have provided greater potential for the emergence of a paternal sky deity. 
Among the established features of male dominance are the hammer axes of the funnel-beaker culture. The patriarchal structure of society is reflected even more clearly in finds from the battle axe culture: men's weapons, battle axes, are central to the culture, whilst equivalent general forms do not occur among women's objects, as was previously pointed out. It is perhaps also symptomatic that, in the initial stages of the culture, men in graves from Central Europe and Denmark were often placed on their right hand side and women - in a mirror image - on their left (Buchvaldek 1969; Brøndsted 1961$62,1,254 \mathrm{f}$.). In the history of semantics it may be observed that the German languages and Finnish, for example, regard "right" in relation to "left" - as meaning "better, morally irreproachable, straight". Thus the emergence or dominance of a sky father would appear to correspond to the social structure north of the Danube, in Central Europe and Southern Scandinavia, at the end of the fourth and throughout the third millenium. Further evidence for tracing the notion back as far as the third millenium, at least, is the fact that Zeus - supposedly of proto-Indo-European origin - must have been brought to Greece by the Acheans round about 2300-1900 B.C.; the name of Zeus is found at Knossos in about 1400 B.C. and at Pylos in about 1200 B.C. (Hiller 1978, 1001-1009). For these reasons, I presume that the Indo-European sky god originated, or at least acquired his dominant position, at the end of the fourth millenium and during the third millenium in the funnel-beaker and battle axe cultures of Central and Northern Europe, i.e. in an area extending roughly from the Rhine to the Vistula and the Dneiper, and from the Danube to Scandinavia and perhaps even to Finland. This is also suggested by the Jupiter Lapis in Rome and Zeus Keraunios in Greece. This is not to say, that the anthropomorphic sky-god should be original or first-born in Europe; considering the similar semitic or other weather-gods in the Near East I will leave the question open.

The evolution of the sky god was certainly not a straightforward process. The period of the many edged hammer axes is followed in the Scandinavian mid-neolithic phase by a period of double axes and passage graves. Passage graves are collective graves built of large stones (Fig. 29), a form which - on the evidence of structural features - is a cultural loan from France or Spain (Kaelas 1966). It is interesting to note that in Spain, Portugal, France and the British Isles they are connected with a female divinity, as is apparent from the female figures and symbolic forms carved there (Fig. 30) (Piggot 1965, tab. 6; Pittioni 1949, fig. 46; Riordain \& Daniel 1964, 126-131): 


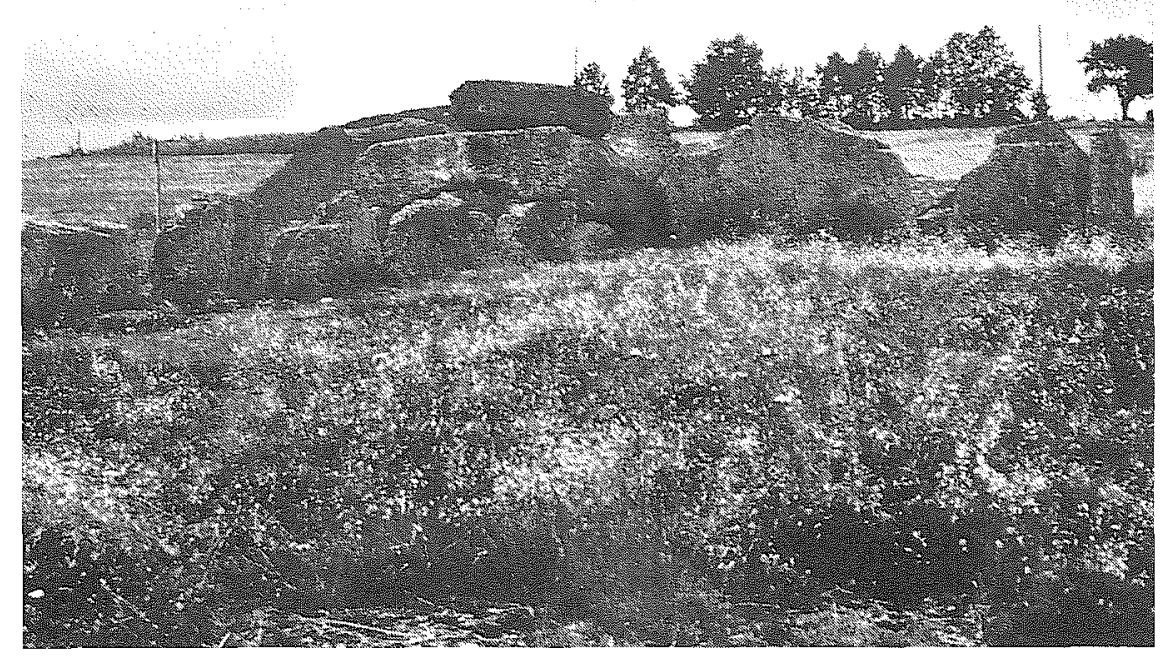

Fig. 29. The monumental Ekornvallen passage grave at Hornborga, Västergotland, excavated from a mound which was originally at least $35 \mathrm{~m}$ in length. The grave has been dated to the middle of the 3rd millenium. (Kaelas 1962).

another guise of the life-giving mother, the taker of life, the ruler of the underworld, known in Scandinavian mythology as Hel. Symbolic representations of her, understandably enough, generally lack a mouth in both Western Europe and the Mediterranean, but the eyes have been drawn all the more emphatically; the same dumb eyes stare out at us from several Danish clay vessels, from the face-shaped emblems on its side (Fig. 31) (Brøndsted 1938-39, 1, 245); Brøndsted admittedly claimed that the pattern had no significance, but the real nature of an eye-goddess has been better sensed since the second World War. The goddess of death in these images sometimes has a decorated belt and clearly a necklace, the same attributes that are found on certain female figures of the Bronze Age; the goddesses of life and death would thus seem to have a certain communality of attributes.

Another occasional sign of the goddess of death in the megalithic graves of Western Europe is a T-shaped weapon, apparently a sym- 

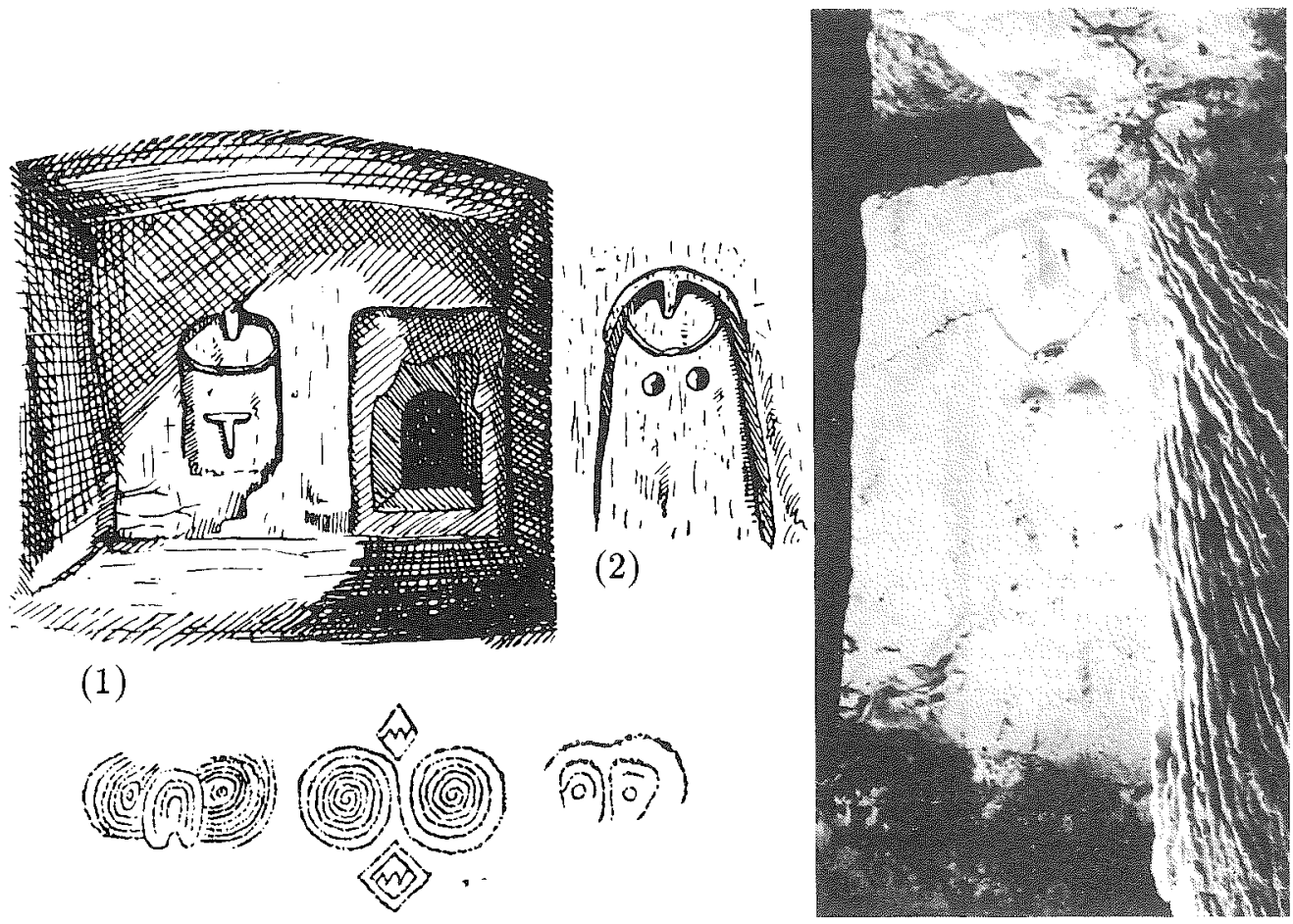

(4)

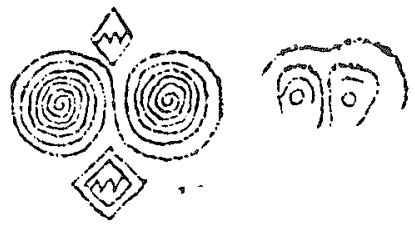

(1)

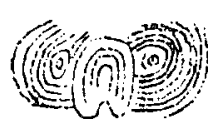

$(2)$

(3)

Fig. 30. Pictures of female deities from cave and tunnel graves. The figure with the double-bladed axe and neck ring carved in the wall of the Cour-jeounet grotto grave (1) may be recognised on the basis of corresponding carvings as a diagrammatic human form, possibly a female form, as shown in a similar picture from the PetitMorin cave (2) or the Coizard, Marne, figure (3). The face of the same goddess or just the eyes are also seen in Irish tunnel graves (4). (Dechelette 1908-14; Piggott 1965; Riordain \& Daniel 1964).

metrical shaft-hole axe (Fig. 30). It may be the same double axe which in Scandinavia is chronologically linked with the passage graves (Fig. 32) (Brøndsted 1938-39, 1, 184 ff.; Kaelas 1957; Stenberger 1964, $181 \mathrm{ff}$.). These double axes succeed the many edges hammer axes of the funnel-beaker culture and also spread to the pitted ware culture. They are skilfully formed and finished weapons, undoubtedly men's weapons; since the same form is also widespread in amber-pendants or pearls, Stenberger is inclined to believe that the axe shapes are 


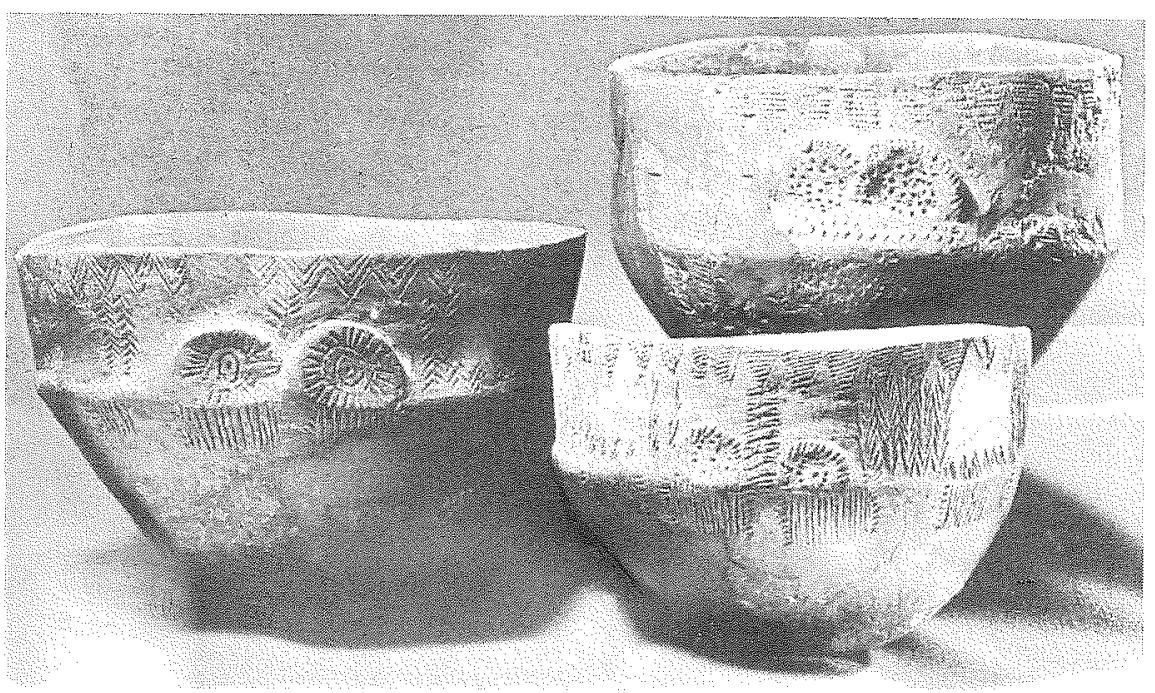

Fig. 31. "Eye goddess" pictured on Danish clay pot finds from the third millenium. National Museum, Copenhagen.

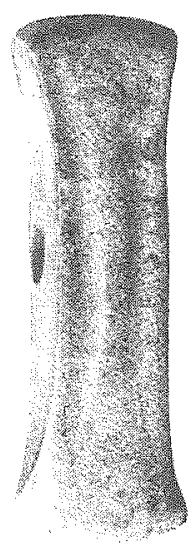

$\dot{s}$

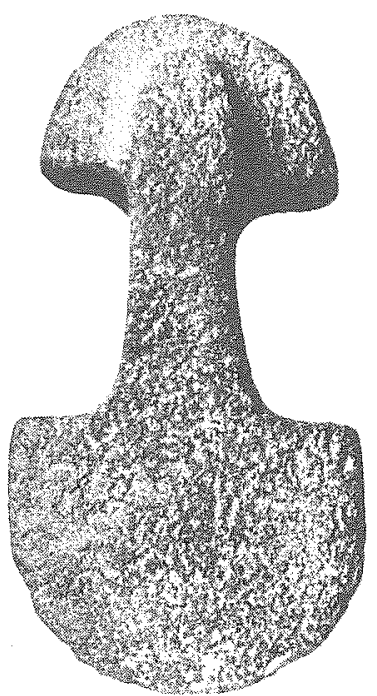

s.

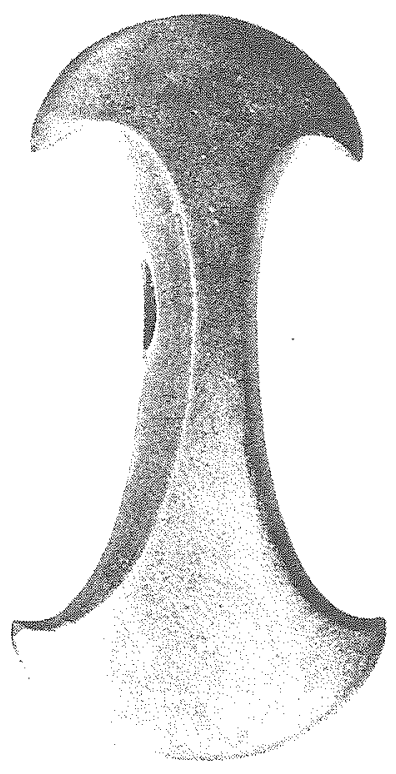

Fig. 92. Danish double-bladed axes from mid-Neolithic times after J. Brøndsted. The axes in the middle and on the right are poor examples of axes but rather exaggeratedly aesthetic and symbolic weapons. Double-bladed axes seen to have been brought to Denmark from the Atlantic seaboard of Europe as were passage graves. (Brøndsted 1938-39, 1). 
symbolic and linked to Mediterranean cultures (Brøndsted 1938-39, 1, 184 ff.; Stenberger 1964, 80 f.). He is surely referring, above all, to the double axes of the Minoan and Mycean Bronze Age culture, the labrys, a name which must be associated with the maze-like figure (Fig. 33), the labyrinth, and which - both for these reasons and in other archaeological contexts - proves to be a symbol of the mother goddess (Fig. 34) (Davaras 1976, $71 \mathrm{ff}$.). It may be added, that the labrys was, according to the Greek myths, the special weapon of the Amazons and in this case also connected with females.

The blades of the double axe - one of them may be a genuinely blade-shaped edge - are often curved, sometimes even semi-circular or scoop-shaped (Brøndsted 1961-62,1,269). The latter shapes are, in view of the stone material, extravagant, and cannot have been usable as weapons, especially the examples made from the easily formed but brittle sandstone. These at least, therefore, must have been cult objects or some kind of symbolic forms, although the same symbolism may be contained in those simpler double axes suitable as weapons, as Stenberger assumed; the evolution of the shape is otherwise difficult to understand. The supposition of symbolism is, however, unsatisfactory without any interpretation; I therefore propose that the double axes with strongly curved blades (Fig. 32), but also other forms more suitable as weapons, are a reference to the crescent of the moon and, through the stages of the moon, to female physiology; there must be some reason for the fact that double axes in the Eastern Mediterranean are so strongly linked to the mother goddess.

By analogical inference, the worship of the mother goddess experienced a renaissance in Scandinavia after the knobbed hammer axes during the mid-neolithic period. It was short-lived, however, because the double axes were superceded by boat-shaped battle axes, which may have been associated with the renewed supremacy of the sky god.

\section{The origin of the god of thunder}

Scholars have drawn attention to the fact that the Indo-Europeans had no common name for the god of thunder. For this reason it is probable that thunder gods evolved after the common Indo-European period. The background may have been provided by a slash and burn culture spreading to Central Europe after the fifth millenium and to Southern Scandinavia at the end of the fourth century. Communities were now more dependent than before on fire and water, the natural 
Fig. 33. Bronze Age miniature labrys of gold from the Arkalochori cave on Crete. (Davaras 1976).

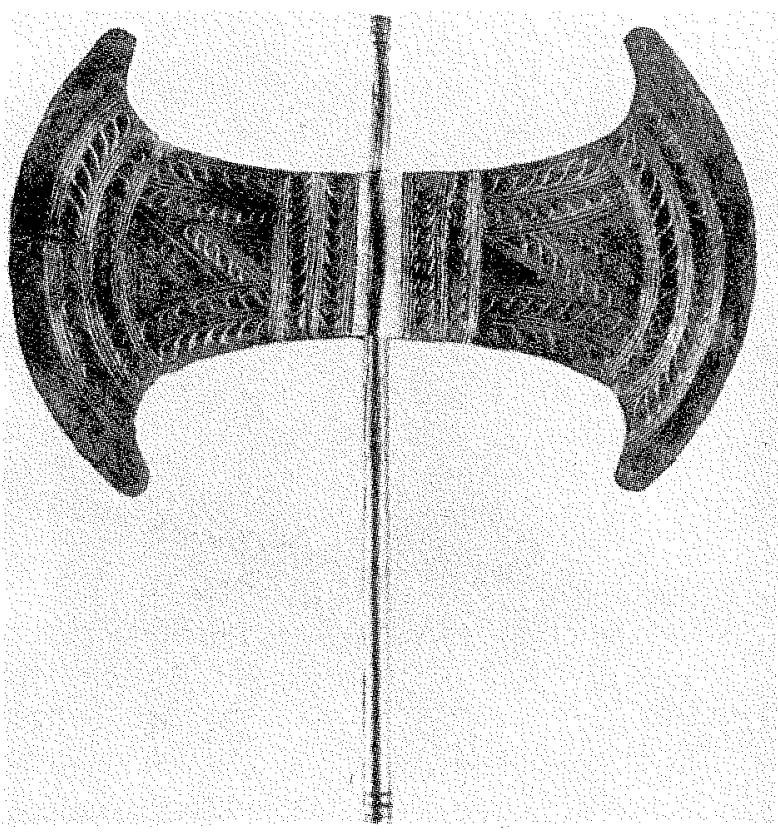

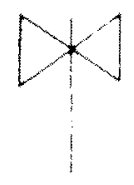

1

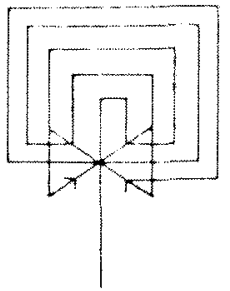

6

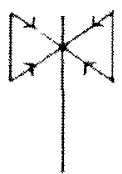

2

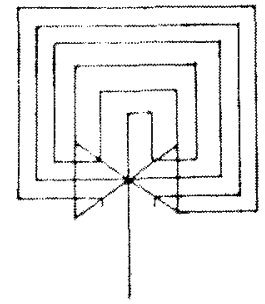

7

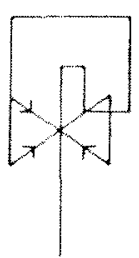

4

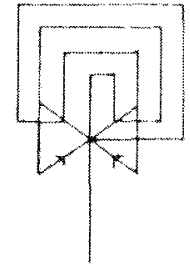

5

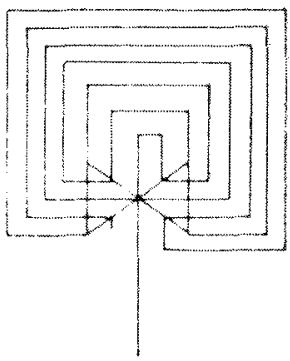

8

Fig. 34. The name labyrinth for a maze is undoubtedly derived from the name of the double-bladed axe labrys. The drawing shows how the labyrinth idea could be evolved from the stone mason's simple representation of a labrys (1). (Davaras 1976). 
elements for the control of which a god of thunder was necessary. A distinctive thunder god certainly emerged from the sky god; the weather, i.e. clouds, winds, rain and thunder, all came under the influence of the sky god. The range of Zeus and Jupiter reflects the special activities derived from a general divinity, but at the same time, these and many other sky gods show that the function of the general deity was preserved side by side with the role of thunder god.

If the emergence of the Indo-European sky god is dated to the end of the fourth millenium or to the beginning of the following one, the period of the hammer axes, the evolution of the thunder god would have to be placed later than this, probably during the battle axe period; in this case it is worth noting that by the end of the third millenium, regional forms of the widespread A-battle axes have evolved, and the original uniformity has been split into divergent tendencies. In any event, the god of thunder must have originated at a period when shaft-hole axes were yet being used as weapons; the change begins to take place towards the end of the third millenium, when the main form of weapon in Central Europe and Scandinavia became the dagger.

I have started from the old notion that the weapon of the thunder god once corresponded to a weapon in general use, the stone hammer axe and the battle axe. It cannot be shown, however, that battle axes of the third millenim, merely by their general nature as a weapon, were the special arm of the thunder god. The same may be true of the lateneolithic shaft-hole axes, although daggers had already arrived. But during the Bronze Age, particularly in its latter stages, the shaft-hole axe of stone had remained - to my mind at least - as the weapon of the thunder god. At that time, shaft-hole axes were already obsolete forms in Scandinavia, not to mention Central Europe. They have admittedly been regarded as working tools, but the arguments are not convincing. Many axes - and this true of those found in Finland, too - are of poor quality stone, which is not suited for working tools; others are of a decorative porphyrite material, which is beautiful when polished, but which was never used in the stone age for proper blades. In some axes the hole is too narrow for adding a shaft, whilst in others only an attempt was made to begin drilling; in a few, there is no hole at all. It is difficult to regard them as work tools, because the working axes of the Bronze Age - the shoulder axe and the socketed axe evolved from the flat, holeless copper axes, and not the shaft-hole axes. Another argument against the working axe interpretation is that the Stone Age predecessors of the Bronze Age shaft-hole axes were not working axes, but weapons. Since bronze was used extensively in 
Scandinavia, and even more so in Central Europe, why were stone axes still manufactured in these areas at the end of the Bronze Age, when far superior metal axes were simultaneously being used? As I understand it, they were not manufactured for this purpose, but the stone shaft-hole axes were used for cult purposes, as hammers of the thunder god, perhaps as votives of the thunder god or to protect people and their homes from lightning. As such, they did not need to be perfect, and the kind of stone used was not important. The conservative character of religious ideas makes the occurrence of stone shaft-hole axes in the Bronze Age quite understandable: they were manufactured from stone because the hammer or axe of the thunder god was also made of stone. ${ }^{9}$

On the basis of the argument presented above, I infer that the stone shaft-hole axes of the Bronze Age may indicate the worship of a thunder god who was Indo-European or of Indo-European origin. The spread of these axes seems to indicate his remarkably broad sphere of influence, in actual fact only its northerly extension; this seems roughly to have covered the former battle axe area and thus to have ranged from the Rhine to the Dneiper and the Volga, and from a zone north of the Danube to Scandinavia, the Baltic countries and Finland. In some places, such as Finland and the northern region of the Black Sea, it spread beyond the original battle axe area. In the northern Black Sea region, sumptuous ornamental axes (Fig. 35) have been found, and one of these - discovered in a mound grave at Horozheno - was decorated with four lightning symbols, at least if they are interpreted in accordance with contemporary notions of symbolism (Sulimirski 1970, 270-275, tab. 37). It thus appears to confirm the proposed link between stone perforated axes in the Bronze Age and the god of thunder, although the axes in question have been interpreted as weapons. It should, however, be added that one single axe in itself is not overwhelming evidence; it represents an exceptional form.

It is difficult, however, to provide direct evidence of an anthropomorphic thunder god going back so far. The figures in rock drawings interpreted as Thor (Vries 1956-57, 2, 125; Ohlmarks 1975, $190 \mathrm{ff}$.) do not take the Scandinavian god back to the Stone Age and do not reveal him as any older than the shaft-hole axes of the Bronze Age. In addition, it appears that at least some enormous images of

9 On the shaft-hole axes of the Bronze Age see Glob 1938; Meinander 1954b, 66-84; Baudou 1960, 47-54; Stenberger 1964, $194 \mathrm{ff}$. 

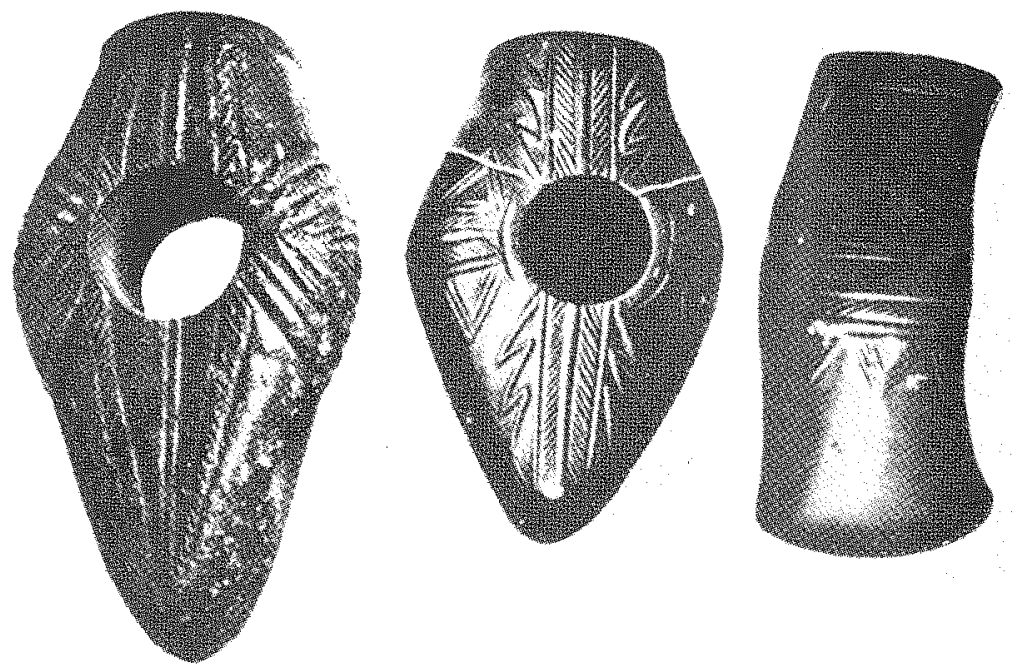

Fig. 35. Ornate Bronze Age shaft-hole axes from the Ukraine. At centre the Horozheno axe, the adornment of which seems to contain the lightning symbol. After A. M. Tallgren. (Sulimirski 1970).

Thor and Odin carved on rocks are more recent than the miniature Bronze Age figures surrounding them, and may not therefore date from the Bronze Age (Hasselrot \& Ohlmarks 1966, 24, 34). The lack of any image of Thor older than the Bronze Age, and perhaps even from the Bronze Age, itself, may be explained by the fact that Scandinavia and Central Europe in the Bronze Age - and as late as the time of Tacitus, too - seem to have been dominated by a noniconic religion, as Bertil Almgren (Almgren 1962) has in many respects convincingly shown. Instead of the gods themselves, the rocks showed their symbols; ships, shields, axes, suns, and sometimes small human figures carrying them. These symbols would have been representatives of the gods and therefore holy, as were - according to Almgren - the pictures of the horseless and riderless chariot, or the footprints carved in the rocks, or their symbols.

Non-iconicity would thus appear to explain many features of the Scandinavian rock drawings. This may not be categorical, however, since Danish and Swedish finds from the end of the Bronze Age (periods $\mathrm{V}$ and VI) in particular, but even from the first half too, include bronze idols, figures interpreted as anthropomorphic gods (e.g. Brøndsted 1961-62, 2, 223 ff., 237 ff.; Stenberger 1964, 202, 298$303)$; corresponding images and divine myths - including the sacred 
marriage - have also been depicted in rock drawings (e.g. Hasselrot $\&$ Ohlmarks 1966, 86-101). If the interpretation of the original noniconicity of the religion is correct, the bronze idols and the corresponding rock pictures would appear to reveal a foreign, presumably Mediterranean influence. Clear evidence of the possibility of such an influence is provided by the miniature bronze statue from Šernai in Lithuania, a picture of the Hurritic thunder god Teshub, or some analogous Hittite deity (Fig. 36): A Syrian or Anatolian god on Baltic soil (Bezzenberger \& Peiser 1909, 424 ff.; Kulikauskas \& Kulikauskiene \& Tautavicius 1961, $100 \mathrm{ff}$; O Okulicz 1973182 f.). As an isolated find, it does not of course justify any binding conclusions: it is at most a sign that religious beliefs from the Levant or Anatolia could have extended their influence as far as this. The figure is regarded as dating from about 1500-1400 (Tallgren 1938, 59 f.; Sulimirski 1970, 276), and is therefore apparently the oldest image of an anthropomorphic thunder god in the Baltic area.

\section{Ukko's arrival in Finland}

The Indo-European god of thunder began to gaze towards the Finnish skies, from the west in the form of Thor and from the Baltic area in the form of Perkunas. As long as the Finnish economy was based primarily on fishing, sealing, hunting and gathering, there was no need for a god of thunder; a god of rain and thunder in human guise was needed only when the Finns started to burn and clear the forest for agriculture. Such burning operations began during the battle-axe period (2500-2000 B.C.), as excavations of the Perkiö settlement at Hauho have revealed (Alhonen 1970). Since the accumulated strata do not contain grain pollen and there are no traces of ears of grain in the clay pottery uncovered, either, burning and clearing the forest in Finland does not seem originally to have been practised for agriculture, not widely at least, but for pasture (Edgren 1970, 53-6; Edgren 1984b; Siiriäinen 1982); to what extent we do not know. As far as pasturage was concerned, a god of thunder was not particularly important, and for hunting such a god was needed even less.

Nonetheless, the battle-axe people probably worshipped him; at least they carried his weapon. The indication provided by battle-axes is confirmed by the fact that the battle-axe people who migrated to Finland from the south are generally believed by archeologists to have been proto-Balts (Moora 1958; Salo 1984c). They could well have 

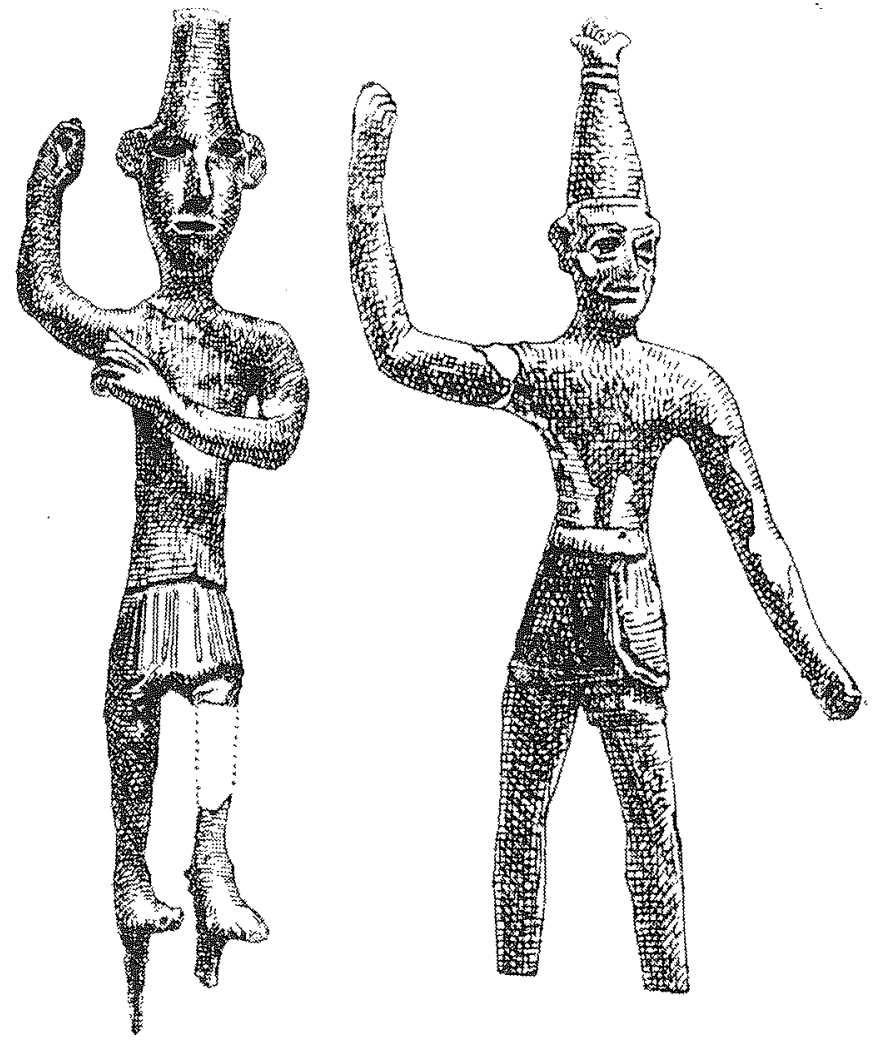

Fig. 36. Small Bronze Age statues of the Hurritic/Canaanite god of thunder, Teshub/Baal. On the left a fragmentary statue from Sernai, Lithuania; the right hand lacks the lightning symbol. On the right a statue found near Tyros dating from 1300 B.C. (Bezzenberger \& Peiser 1909).

brought a god of the sky to the Finnish skies. Moreover, it would seem fairly natural that the loan of the proto-Balt taivas 'sky' is the best explanation for the emphasis on the word itself, although there can be no certainty of the the reason for the loan.

The comb-ceramic people, who may be regarded as early protoFinns, would have become acquainted with the cult of these new arrivals in the actual battle-axe area of southern and western Finland, where some of them remained and settled. The Finns would also have come to know the new cult outside the core areas, in central, eastern and northern Finland, where they continued their former life style undisturbed. This co-existence in Finland does not seem to have left any marked traces on comb-ceramic culture in the battleaxe area of Finland although it is occasionally seen in pottery remains 


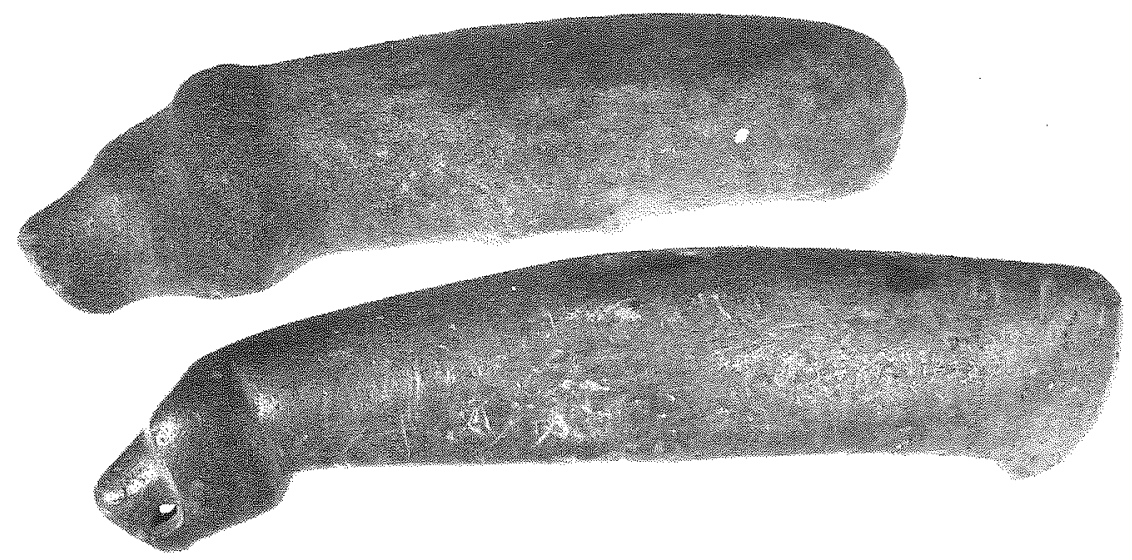

Fig. 37. Cult axes of hunting culture. Bearhead axes from above) Papinniemi, Heinävesi and below) Kaisatholma, Antrea, Karelian Isthmus, USSR. The axes show that the influence of battle-axe culture also extended into the area of late comb-ceramic culture. National Museum, Helsinki. Photo: R. Bäckman, National Board of Antiquities.

(Meinander 1939; Vikkula 1984). Nor is the close proximity of the two cultures reflected in battle-axe culture. More obvious influences of the new culture can be seen outside the battle-axe area in the wellknown copies of battle axes found in the interior of Finland and its eastern parts. Here the axe part was sometimes carved in the form of an elk's or bear's head (Fig. 37) (Äyräpää 1952). In fact, stone bear and elk heads continue the tradition of animal weapons derived from Suomusjärvi culture, continuing it with even greater vigour (Carpelan 1974; Carpelan 1975). The elk and the bear, the images used, were obviously animal deities of hunting culture or else totem animals. Since the influence of the battle-axe period is reflected in these objects, it could not have been entirely superficial.

Traces of the battle-axe period are seen at their strongest, however, only during the following phase, the Kiukais culture (2000-1400/1200 B.C.) that followed the late comb-ceramic and battle-axe periods, in its battle axes and other shaft-hole axes, in some of the decorations on its pots and its cultivation of barley (Meinander 1954a; Pihlman \& Seppä-Heikka 1985, Siiriäinen 1982). This is, however, a question of a legacy since the Kiukais period has been interpreted as a fusion of the comb-ceramic and battle-axe cultures in which comb-ceramic 


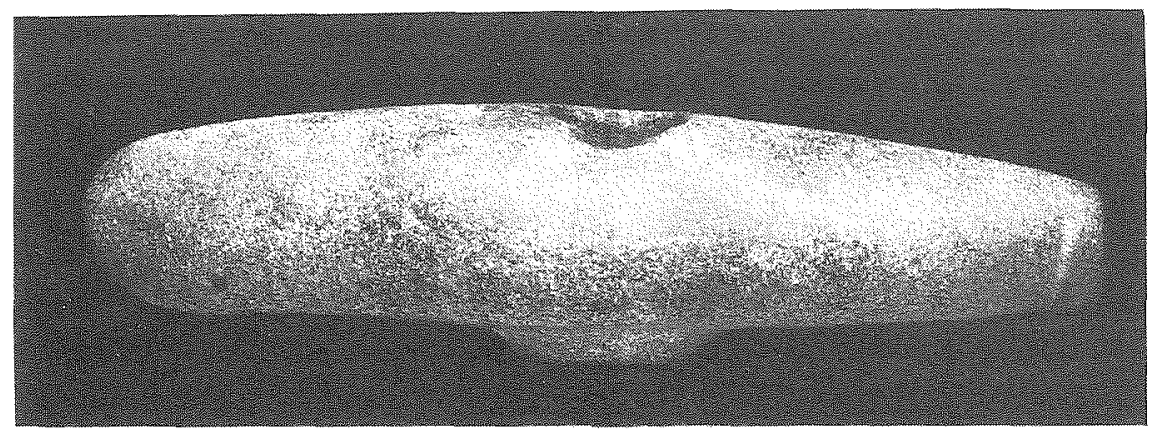

Fig. 38. Tapering headed Esthonian-type battle-axe from Reitkalli, Vehkalahti. National Museum, Helsinki. Photo: R. Bäckman, National Board of Antiquities.

features predominated and which thus signifies the preservation of the proto-Finnish ethnos.

The whole legacy of battle-axe culture does not, however, seem to have derived from Finnish origins; it also had Scandinavian and southern Baltic links (Meinander 1954a, 168-84). And it was also influenced by a new wave of battle-axe culture from Estonia. Some late forms of Estonian battle axes, tapering axes, reached Finland and were even brought to areas outside the old battle-axe area (Fig. 38). These late forms were relatively common (by 1922 some 80 had been found) and apparently reached Finland at the end of the battle-axe period or after it (Soikkeli 1912; Äyräpää 1922, $106 \mathrm{f}$.). As there is no reason to assume that the local Finnish battle-axe people adopted the Estonian style and relinquished their own, it would seem natural to conclude that the new type was brought by a new wave of immigrants. The southern origin of the new axes is attested by the fact that many of them are made of uralite-porphyrite, a type of stone often used in Estonia, or other similar kinds of stone, in other words from materials not used by Finnish makers of battle axes. The depths at which

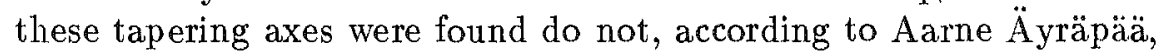
correspond to burial levels of the battle-axe period proper nor have they been discovered with cord pottery. The differences in form, material, distribution and conditions in which the find were made led Äyräpää to conclude that tapering axes did not belong to the "Finnish battle-axe period proper". From them, nevertheless, developed the flat shaft-hole axes of the Kiukais period even though finds of these are not very common (Meinander $1954 \mathrm{a}, 76 \mathrm{ff}$.). It is possible that this 
final wave of battle-axe culture also spread to Finland other features of proto-Baltic culture. If the immigrants were proto-Balts, they may have assimilated to some extent with comb-ceramic people when still in Estonia but they may just as well have been comb-ceramic people who adopted features of battle-axe culture. They do not at least appear to have been isolated from the old population, as was the case with earlier immigrants, not at least judging by the evidence provided by the distribution of tapering axes.

Proto-Baltic loanwords in Balto-Fennic languages correspond in both their southern origin and their meaning so closely with battle-axe culture that they can actually be identified with it, as Harri Moora was the first to point out. Furthermore, I would like to draw attention to the fact that no archeological features of any other period can be so clearly linked with Baltic loanwords even though some of the loanwords are of course of later date. The archeological development as a result of which battle-axe culture disappeared in Estonia and Finland while the comb-ceramic tradition was preserved, albeit modified by the influence of the battle-axe period, corresponds completely to philological developments. This shows that the proto-Finnish ethnos was preserved, not admittedly unchanged but enriched with protoBaltic loanwords and the cultural features to which they attest. This correspondence between philological and archeological features can be illustrated with a number of examples.

Battle-axe features are indicated by the proto-Baltic loanwords (Kalima 1936; Koivulehto 1979; Suhonen 1984) kirves 'axe', which may have been used for battle axes or for straight-bladed working axes - both forms unknown previously to the comb-ceramic people - and vaaja 'wedge', which may have been the name for the shoulder axe or cleaver. Several loanwords for domestic animals and their care, e.g. oinas 'ram', vuohi 'goat', villa 'wool', harja 'mane', karva 'hair', vuota 'hide' and paimen 'herdsman' have direct equivalents or background in the bone finds of the Estonian battle-axe period and immediately following era (Jaanits 1982, 101-20). The Baltic loanword ohra 'barley' means the grain with which the history of agriculture in Finland began during the Kiukais period. Many other Baltic loans would seem to have been borrowed in connection with the raising of crops, such terms for natural phenomena as halla 'frost', heinä 'hay', luhta 'marsh' and routa 'ground frost'. Of particular interest in this context is the word taivas 'sky' since its analogues in the the Baltic languages mean 'god' (Kalima 1936, 163). Scholars have long known that this word have the same origin as the Greek Zeus or the first part of the vocative form 
of Jupiter *dieu pater 'heavenly father'; as mentioned above they also have their equivalents in Sanskrit (Wachsmuth 1964-75, 1516 ff.).

If the Finnish taivas is of Baltic origin, then in the Baltic languages the meaning of the word would, as in certain other languages, have moved on from the meaning 'sky' to that of 'god'. The Baltic origin of taivas has been questioned, however, because the Baltic equivalents do not have the meaning of 'sky', a meaning which is unique in the Balto-Fennic languages. It has therefore been considered possible that the word derives from one of the Arian languages, in which this meaning has been preserved (SKES $1202 \mathrm{f}$.). The purely BaltoFennic distribution of the word does not, however, accord very well with such early borrowing; consequently, a proto-Baltic origin would appear more plausible. This presupposes, however, either that the word also had the meaning 'sky' in proto-Baltic and that the protoFinns had adopted only that meaning or that the transition from 'sky' to 'god' took place in the Baltic languages only after the word had been borrowed by the Finns.

From this it would in any case seem to follow that Ukko could probably not have been of such old southern origin if taivas had also meant 'father from the sky' at the time it was borrowed. It may suffice as explanation that the gods of agriculture still had no significance in Finland during the battle-axe period, perhaps not even during the early stages of the Kiukais period. The Finnish word perkele and its equivalents in Karelian, Votic and Estonian can admittedly be linked with the Baltic god of thunder, Perkunas (Kalima 1936, 147; SKES $523 \mathrm{f}$.) but as the word does not mean 'god of thunder' but only 'enemy of the soul' or 'hell', it was probably not borrowed by the Estonian and Finnish languages until the early Christian era. The dualistic nature of Christianity, in which respect it differed from the early Finnish religions, naturally needed to personify evil even in its missionary stage. Thus it was perhaps safer to adopt for this purpose the foreign Perkunas than the local derivative Ukko, who was feared and respected. The distribution of the word perkele is too restricted as an old loan and, besides, it seems to have been borrowed by Karelian and Votic from Finnish and Estonian.

A second possible provenance for the weather god Ukko is the west; this theory will be studied below. Krohn and Harva were the first to demonstrate that there are close equivalents to several of Ukko's characteristics in the Scandinavian linguistic areas and in Scandinavian culture. For example, the names Ukko, Ukkonen, Isä and Isänen can be compared in meaning with Gamaltor in Norwegian, Gamle 
Oldfader in Danish and Godfar in Swedish (Krohn 1914, 118; Harva $1948,87)$. The variants in nomenclature can therefore be explained as translation loans, and the Tuuri of ancient runes may well be a late loan despite its probable prehistoric character. Moreover, many attributes link Ukko with the Scandinavian god of thunder, as Harva has pointed out. How long Ukko has been a Finnish deity, however, is not clear from these similarities even though Ukko clearly has older features compared with the Thor of the viking period. Even in late popular tradition. Ukko struck lightning, rained and made the earth fertile whereas in sagas about Thor the first two functions had been largely forgotten.

Archeological evidence, however, provides us with certain indications of the time of Ukko's arrival or his existence. If Ukko came from the west, the earliest possible point - terminus post quem - is the date at which sea links started between Finland and Sweden in late comb-ceramic times, during the third century. The first indication of such links is the many-edged hammer axe found at Hämeenniemi, Lapua, for example, but evidence of more numerous contacts in the latter half of the century is reflected in some battle axes, battle-axe graves and Pyheensilta pottery (Salo 1988). Firm proof, however, comes only with the Kiukais period in the early second century. Is it possible that Ukkonen had already crossed the Gulf of Bothnia by then? Support for such a theory might be found in the start of barley cultivation (Turku, Niuskala) and grinding stones found in the area between the Kokemäki and Aura rivers (Meinander 1954a, 85-92). Unfortunately we do not have sufficient knowledge of the extent and importance of agriculture during this period, and the Baltic origin of the word ohra 'barley' would seem to contradict the possibility of its cultivation coming from the west. Kiukais culture, moreover, had clear contacts with the Baltic area, too. On the other hand, we know that in Kiukais circles the making of sacred figures - elk-head clubs and axes - typical of hunting culture was still common (Meinander 1954a, 85-92). From this it may be concluded that the new god had not yet won over the people even though he might already have arrived on the scene.

More probable, however, is that the Scandinavian god of thunder did not arrive until the Bronze Age, after the middle of the second millenium B.C. At this time culture along the littoral changed so markedly as a result with contacts with the west that it became the most Scandinavian of all Finnish prehistorical cultures. Scandinavian influence is reflected not just in artefacts but also in the structure 
of society and in religion; this can be concluded from the adoption of Scandinavian long houses and, above all, of Scandinavian stone burial mounds. It is generally accepted that the cultural change derived from proto-Germanic immigrants who settled along the coast of Finland in the latter half of the second millenium, principally in the archipelago and in areas between proto-Finnish settlement (Salo 1981, 424-37). They may well have brought their anthropomorphic god of thunder with them; certainly the intensification of agriculture during this period compared with the Stone Age provided fertile ground for his introduction.

For similar reasons the anthropomorphic god of thunder can really be linked with the Scandinavian and also southern shaft-hole axes which were brought to Finland during the Bronze Age and also imitated there (Fig. 39). Best-known in the region between the Kymijoki and Kyrönjoki rivers, i.e. the area of coastal culture, like stone burial mounds they also spread to the Lakes Region, and less frequently as far as the shores of the upper course of Päijänne. Some such axes have even been found in Karelia but they seem to be lacking from the southern core area of the Vuoksi water course, where the old rock art was preserved (Meinander 1954b, 66-77; Salo 1981, 285-96). Against this background it may be assumed that the god of thunder with its Scandinavian origin has struck lightning and thunder and brought rain in Finland for at least three thousand years. At the same time Ukko obviously began to replace the old animal deities of hunting culture since animal-head weapons and utensils seem no longer to have been made during the Bronze Age even though rock art from the hunting period continued farther east along the Saimaa chain of lakes, a region which in my view must be characterised as Saami, almost to the beginning of the new chronology (Salo 1984a, 178).

Agricola's portrayal of the Karelian character of Ukko does not, however, agree with the western character of Ukko, in favour of which the Scandinavian shaft-hole axes of the Bronze Age seem to speak. Nor does it agree particularly well with the fact that Ukko is to some extent common to the whole country and that the names ukonilma, ukkosenilma, ukkonen 'thundery weather' are general throughout the Finnish language (SKES, $1524 \mathrm{f}$.). In the light of this and later also the similarity between Ukko's and Thor's features and the semantic correspondence of their names it has long been customary to reject the idea that Ukko was of Karelian origin. This view is further confirmed at first sight by the evidence of this study: the Scandinavian shafthole axes of the Bronze Age and the elliptical fire stones of the Iron 


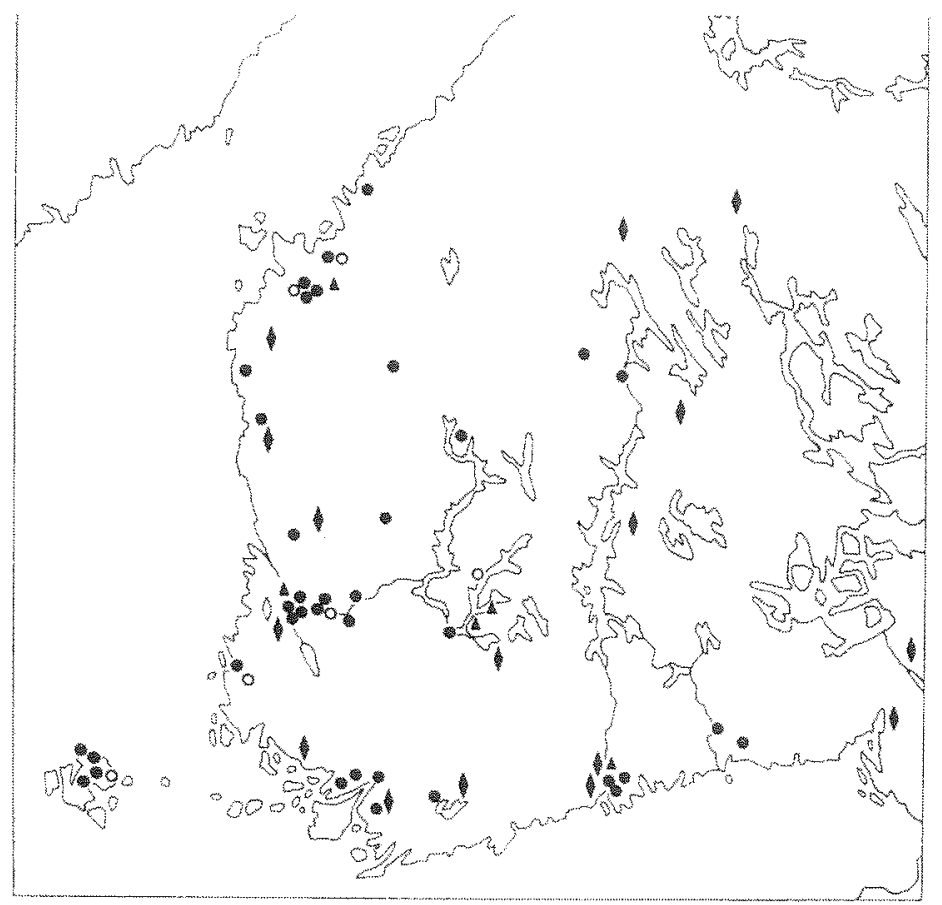

Fig. 39. Distribution of stone shaft-hole axes in southern Finland in the late Bronze Age after Unto Salo. The circles indicate Scandinavian forms, the triangles southern forms reminiscent of Lausitz culture. The rhombs indicate sharp-edged rhomb axes, some of which are double-bladed, however, and not perhaps the weapons of the god of thunder.

Age have been found pre-dominantly in western Finland so that the idea of Ukko originating from Karelia seems improbable. Nonetheless, we should consider the reasons why Agricola believed that Ukko came from Karelia even though we cannot of course arrive at any definite conclusion.

Agricola's characterisation can be explained in different ways. First of all, it is clear that the custom of drinking Ukko's cup, to which Agricola attached chief interest, had been preserved in the 16 th century more strongly in eastern Finland than in the west; there are numerous reports from Savo and Karelia in the 16th and 17th centuries and one from Hauho in Häme is even dated as late as 1662 (Harva $1948,103-22$; SKES, 1524 f.). The custom of drinking Ukko's toast continued at Rautalampi and Kurkijoki right up to the 19th century. 
The geographical distribution of Ukko's toast may well have indicated an eastern Finnish provenance in Agricola's time. Agricola perhaps also knew that the word ukko in the sense of 'old man', 'married man', 'grandfather' was not used in south-western dialects nor in the language spoken in Satakunta. For this reason $u k k o$ as a name for the god of thunder seemed to point to the east, the area where the word $u k k o$ was in widespread use (SKES, 1524). Agricola may therefore have had a rational basis for believing that Ukko was of Karelian origin.

Although the eastern distribution of the custom of drinking Ukko's toast at Agricola's time may not be of importance as far as the early stages of Ukko's history are concerned, there remains the name, Ukko. According to SKES ukko is known as a name for the god of thunder in Finnish, Karelian and Veps. It also appears in Votic and, rarely, in Estonian; in both cases it is believed to have been borrowed from Finnish. That it is restricted in its distribution to the northern half of the Balto-Fennic area indicates its philological lateness and agrees well with the theory of Ukko's provenance given above: it can probably be dated to one and a half thousand years after common proto-Finnish time. Philologically Ukko is, then, late proto-Finnish or Finnish, geographically Fenno-Karelian.

It would seem natural that the common name for the god of thunder should come from the general area where the word ukko was used, i.e. the whole of Finland with the exception of Satakunta and the southwestern dialects (SKES, 1924). This would presuppose that the Ukko of the Karelians was at some time very expansive. There is, however, no reason to believe that the name spread to the southwest of the country in historical time. Ukko's possible spread does not fit in with the Iron Age or the late Bronze Age, either, since the distribution of early evidence of Ukko, namely elliptical fire stones and Bronze-Age shaft-hole axes, is concentrated to the west of Finland; Karelia clearly constitutes a marginal area in this respect. Such considerations lead to the conclusion that the spread of the name Ukko must have occurred so early that it had no rivals. The name $U k k o$ for the god of thunder must therefore go back to the beginning of the Bronze Age at least. This in turn would presuppose that Ukko was older in Karelia than the existence of a god of thunder in western Finland.

Can such an idea find support in archeological evidence? The first and at the same time most interesting indication is a shaft-hole club found at Kiuruvesi in northern Savo (fig. 40). The club is made of uralite-porphyrite and is a carefully made artefact reminiscent of 


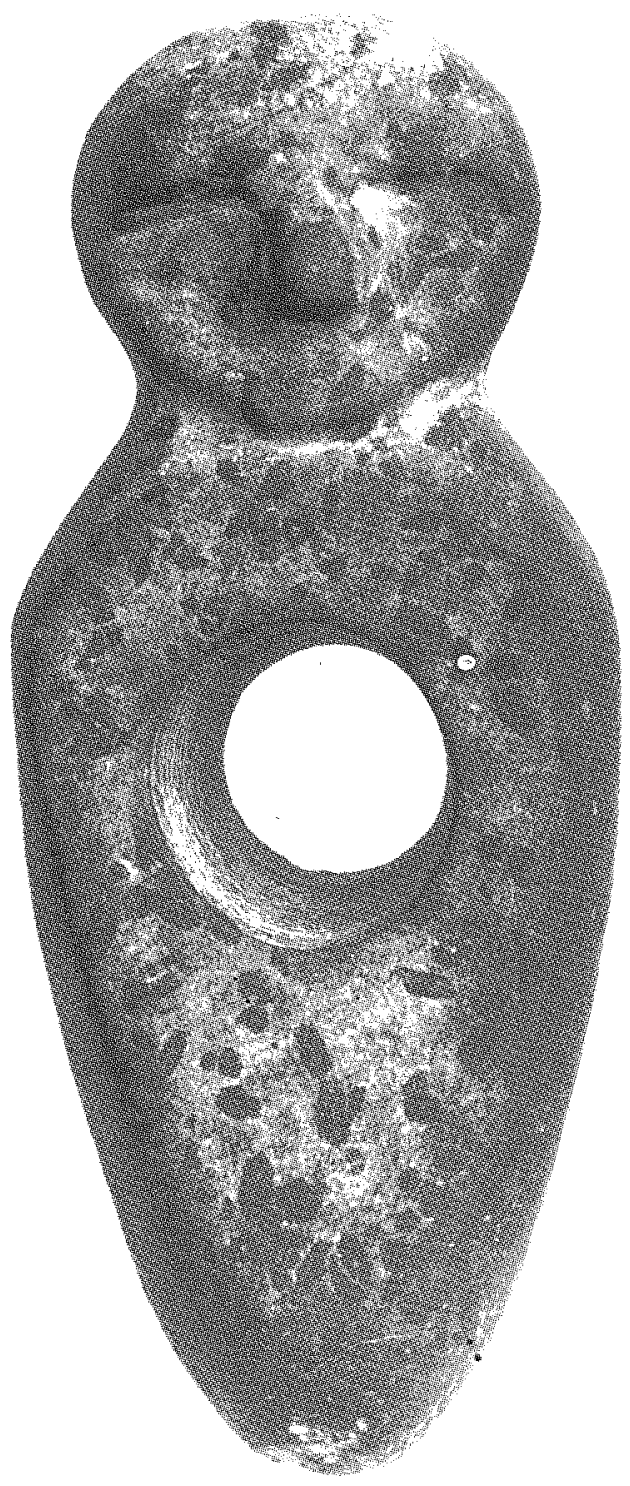

Fig. 40. Cult club from Kiuruvesi, northern Savo. National Museum, Helsinki. The club, which is made of uralite-porphyrite, a material seldom used in Finland, is without like. The object is obviously connected with the old animal-head weapon tradition but was probably dedicated to an anthropomorphic god of thunder. Photo: E. Laakso, National Board of Antiquities. 
a shaft-hole axe but it has no cutting edge (Meinander 1954a, 90; Lehtosalo-Hilander 1988, $106 \mathrm{ff}$.). The most astounding feature of the club is a round idol-like head carved in the neck, complete with a broad nose and eye hollows but lacking a mouth. Although no such similar objects are known, it may be concluded that the club is a cult object and, judging by its form, related to animal-head weapons but connected with an anthropomorphic deity. It would seem to continue the tradition of animal-head axes or clubs the core area of which was Finland and the Aunus (Meinander 1954a, 85-93; Carpelan 1974, 1975).

The idea that immediately springs to mind is that the club portrays the god of thunder, and the club has indeed been suggested to be a cult object dedicated to him (Gelling \& Ellis Davidson 1969). If this interpretation is correct, then it would probably be the oldest representation of the god of thunder in northern Europe. The incomplete form of the face neither supports nor contradicts such an interpretation. The object was found at a depth of one metre, in the bottom sediment of a former lake. It may have been thrown into the water intentionally, (Lehtosalo-Hilander 1988, 107 f.). Elliptical fire stones have often been found in similar locations, as was mentioned earlier, and likewise shaft-hole axes (e.g. Salo 1981, 285-96), both of them objects associated with Ukko. However, since other kinds of objects were also thrown into the water as a form of sacrifice in Stone Age times, the similarity cannot confirm the theory with any certainty.

The club cannot be dated exactly. The hole bored in the shaft militates against a dating prior to the battle-axe period but even the battle-axe period seems early. The advanced level of stone technology indicates that the club cannot be younger than the late Bronze Age but a late Bronze Age dating might well be too late. The club is probably from the second millenium before Christ, perhaps more exactly from the time of Kiukais culture, to which Meinander and Lehtosalo-Hilander believe it belong. Such a dating finds some support in the fact that the material of which the club is made, uraliteporphyrite, was used very rarely for Finnish artefacts during the Stone Age. However, it was used for the tapering axes that spread from Estonia to Finland during the early Kiukais period, or even the end of the Finnish battle-axe period. In other words, the use of uraliteporphyrite may reflect Estonian influence but the club can hardly have been Estonian since the tradition of animal-head weapons suggested by the club did not exist in Estonia. The material of the club is probably Finnish as uralite-porphyrite is found in southern and central Finland 
(Meinander 1954a, 92). If the above interpretations are correct, then the Kiuruvesi club would suggest the existence of an anthropomorphic god of thunder in Finland as early as the beginning of the second millenium before Christ. No such evidence of this age has been found in western Finland, but even the dating of the Kiuruvesi club cannot be regarded as certain.

Attention may also be directed to straight-backed battle axes and sharp-edged rhomb-shaped axes. Straight-backed axes (Meinander 1954a, 84 f.) spread to Finland and the Baltic countries from eastern Russia. If they were the weapons of the god of thunder there, it is possible that they also served the same purpose in Finland, too. The material, stone, is no proof, however, of the correct date as the oldest axes go back to the end of the battle-axe period and to Kiukais times, when stone was still the most commonly used material for cutting edges and weapons. The cult axe interpretation can only be applied to degenerated examples which, according to Meinander, belong to the Bronze Age. It is interesting in this context that six of the seventeen straight-backed axes known to Meinander were found in Karelia and Savo while only five were found in the battle-axe area proper.

Sharp-edged rhomb-shaped axes, which Evert Baudou claims are from the early Bronze Age, differ in their distribution from the shafthole axes of the Scandinavian Bronze Age. Although known throughout the whole of Finland, including Karelia and along the Kymijoki watercourse, most of them have been found in coast culture areas (Meinander 1954b, 80 ff.; Baudou 1960, 287 f.; Salo 1981, 287-96). They may have been cult, and consequently Ukko's, weapons but that is not sufficient to prove that Ukko was of older date in Karelia than along the coast. Thus, with the exception of the Kiuruvesi club, there is probably no archeological evidence to support the idea that Ukko was of Karelian origin. And the importance of the club is reduced by the uncertain dating, which can be based only on general conclusions.

However, the possibility that Ukko is of greater age in Karelia can also be studied from the philological perspective, on the basis of early proto-Finnish non-Germanic words for agriculture and cattle raising. These words must be at least as old as proto-Germanic loanwords. They include the Fenno-Ugrian uuhi 'ewe', the FennoPermian jyvä 'ear (of corn)', the Fenno-Volgan jauhaa 'grind', vehnä 'wheat', lehmä 'cow' and lypsää 'milk' and the Baltic ohra 'barley', oinas 'ram', vuohi '(she) goat', vohla 'kid', villa 'wool' and paimen 'herdsman' (SKES 115 f, 129, 284, 318, 422, 459, 1559-60, 1683, 1766 f., 1802, 1814 f.; Koivulehto 1979; Koivulehto 1983a; Koivulehto 
1983b; Suhonen 1984). The latter group goes back to the battle-axe period or, at the latest, to Kiukais culture, as mentioned above. The others could be dated on the basis of the philological interpretation given above to the comb-ceramic period proper but such an early cultural background in Finland does not really fit. Nor do they fit in with the late comb-ceramic period since the livelihood of the Finns at that time was based on hunting and fishing. For this reason they were probably not borrowed by proto-Finnish until later, from the direction of the Upper Volga.

The common features of Pyheensilta, Pöljä and Kierikki ceramics, of Tamula pottery from Estonia and Volosov pottery from Oka-Volga (Meinander 1984, $37 \mathrm{ff}$; Meinander 1983) are probably indicative of new contacts with the Volga area, i.e. later than the actual combceramic period. This is the end of the third millenium B.C. The influence of an economy based on agriculture, however, cannot be seen until earliest textile-ceramic times, which spread from the direction of the Volga to Kiukais culture (2000-1400/1200), apparently in its early stages, and to east and north Finland to the Pöljä group in the later stages (Meinander 1954a, 139-40, 165). It provides evidence of the spread of weaving, the raw material of which was probably fibres from the wild nettle; this material was used in Central Europe at least in the Middle Ages and in the Fenno-Ugrian area much later (Sirelius 1921, 58). It is not too far-fetched, however, to imagine that sheep raising and with it the Fenno-Ugrian uuhi reached Finland at this time. An equally ancient dating is probable for the loan of oinas and villa from proto-Baltic.

The following wave of an agricultural culture seems to have come with new textile ceramics, during the Sarsa ceramic period, in the middle or latter half of the second millenium (Meinander 1954b, 1829 ). It seems to have originated from the territory southeast of Ladoga, from Aunus and the Karelian Isthmus. From the Isthmus it spread in a narrow wedge in the direction of the Salpaus ridge to southern Häme and the Kokemäki water-course; the most westerly settlements are known to have been in Vammala, Laitila and Karjaa (Salo 1981, 10313; Meinander 1984a, 41 ff.; Heikkurinen \& Suominen 1982). A second stream led via the eastern margins of Finnish Karelia and perhaps even farther east to northern Finland and Lapland (Huurre 1983, 24651). This wave of emigration was probably small in size (Salo 1981, $377 \mathrm{f}$.). The Sarsa ceramic period is known only from settlements along lakesides suited to fishing; no other objects associated with this period have been found. However, as the textile-ceramic people living along 
the Volga derived their livelihood from agriculture, I have regarded it as possible that the same kind of economy was also associated with the Sarsa ceramic period in Finland (Salo 1981, $377 \mathrm{f}$.). More recently Meinander has linked the earliest finds of grain pollen - either cereal pollen in general or in some cases barley and wheat pollen - with the arrival of textile-ceramics as they cover roughly the same time and same area (Meinander 1983). The interpretation seems natural and agriculture seems to have spread along the Kokemäki watercourse from the east, in approximately 1500-1300 B.C. (Meinander 1983, tab. p. 12).

The oldest terms associated with agriculture and cattle raising have, on the whole, followed the same route. Vehnä has its direct equivalent in the oldest pollen grains and lehmä in the "bull's tooth" of Uotinmäki, Kiukainen (Ailio 1909, 19). The verb jauhaa corresponds to the grinding stones found at Kiukais settlements from the mouth of the Kokemäki river to the Aura. They provide a dating for the word and what it signified to the middle of the second millenium B.C. at the latest but differ from Sarsa ceramic finds by reason of their concentration to coastal locations. On the basis of their distribution they might perhaps better be associated with the first wave of textile-ceramic immigration and dated to the beginning of the second millenium. However, there is no indication of the direction from which grinding stones reached Finland; if it was Scandinavia or the Baltic countries, there does not seem to have been any corresponding loanword associated with them. Nor do we have any pollen evidence of such early cultivation, either from the inland or from the coast, but this may be a matter of lack of evidence since barley was grown on Aland in pit-ceramic times as early as the end of the third millenium (Lindquist 1988).

On the basis of the philological evidence described here it seems reasonable to conclude that a grain-growing economy began in southern Finland under the influence of impulses from the Volga and the Baltic countries apparently even before contacts with proto-Germanic peoples during the Bronze Age and the probable immigration of the protoGermans. Against this background may be set the god of clearing and cultivating, Ukko, for cultivation did not in all probability begin without the religious beliefs that accompanied it. Such a chronology and diffusion would also explain how the eastern Finnish name Ukko reached the west of Finland. Despite its Volgan background the original source of Sarsa ceramic culture was the Ladoga region, perhaps even the Karelian Isthmus, as I mentioned earlier; it was there that 
the Indo-European god of thunder got his general Finnish name. Ukko was an honorary title but at the same time a euphemism and does not reveal from where the deity had come to Karelia. A Volgan, textileceramic origin would seem natural, in fact, but since the most closely related Finnish tribes of the Upper Volga, the Merjans and Muromans have disappeared, the problem remains unsolved. The fact that the Mordvinians and the Mari (Cheremis) know no such god gives rise to suspicion. For this reason the possibility of a Baltic provenance for Ukko must be taken into account.

If, in accordance with this hypothesis, Ukko was first worshipped in western Finland during the time of the Sarsa ceramic people, then he was confronted along the coast and in the archipelago by another, western, god of thunder who had presumably arrived with the immigrants from the west. The two gods of thunder obviously merged with each other; Ukko retained his name but over the centuries came to liken the Scandinavian Thor. Not entirely, however; he did not drive a chariot drawn by goats nor was a colourful hoard of myths spun about him like about Thor for around Thor, there revolved priests and poets, gódar (Norse priest-chieftains) and skalds. Iron-Age Finland did not boast the same kind of hierarchical society as existed in Scandinavia; here it was peasant storytellers who recited Ukko's myths. In their verses they asked for Ukko's help in purely practical matters: to make fire, to burn and clear the forest, for the fruitfulness of the soil, for rain, for hunting spoils, for birth, or in their fear they bade Ukko strike elsewhere. Ukko remained the natural violent thunder god of the clearers and burners of the forest although in other contexts he also exhibited the refined characteristics of a heavenly deity. As such Ukko was probably more reminiscent of the Thor of the Swedish peasantry than the heroic god of the sagas.

\section{The Sky Bird}

In his study of Ukko Uno Harva writes that "according to the beliefs of the northermost tribes of Asia and the North American Indians thunder is represented as a giant bird which makes a mighty roar as it flies. The Tungusi believe that the thunder bird has stone claws with which it shatters the trees of the forest and which can sometimes be found on the ground" (Harva 1948, 74, $90 \mathrm{f}$.). According to Harva the Finns may have had similar conceptions since the parallel name for the thunderbolt, well-known of old, ukonkynsi, ukkosenkynsi, 
'Ukko's nail or claw', of which there are records from Karelia, Savo, Kainuu and southern Lapland, does not seem to be appropriate for an anthropomorphic god of thunder. "Did the Finns, in whose beliefs may be detected strata from different periods, also preserve such a primitive concept for the producer of thunder? In considering this", writes Harva, "we should also bear in mind the words of the ancient poem 'ukko the oldest bird in the sky' or 'struck fire from his claws" (SKVR 1:4, 277, 291). He also quotes the old verse

Tule Ukko ottamahan, kivikynsi kiskomahan kivisillä kynsilläsi.
Come Ukko, and take with your stone claw, with your talons of stone.

Seen from the perspective of Finnish prehistory that existed at that time, the concept was a bold one, and Harva did not proceed to examine this idea more closely; perhaps he did not know any other keys to the problem in the source materials.

However, certain references may be presented. I shall direct attention to the verses about the origin of fire given above (Leppäaho 1949a, $71 \mathrm{ff} ., 87)$ :

Iski tulta Ilmanukko,

Välähytti Väinämöinen

Kolmella kokon sulalla,

Viiellä vivutsimella.

or

Kolmell' on kokon sulalla,

Viijell' on vivuttimella,

Kajahutt' on kallivoho.

(SKVR 1:4, 236)

or

Sulitti tulisen nuolen

Kokon kaihilla sulilla,

Varpusen vipusimilla.

(SKVR 12:2, 5526)

Or

Itse vanha Väinämöinen

Iski tulta kyntehensä,

Järkytti jäsenehensä.

(SKVR 1: 4, 270, 272; 9:4, 1057; 12:1, 4487, 4555; 12:2, 8511).

The view based on Jorma Leppäaho's interpretation was given above that the kolme kokon (kotkan) sulkaa (three eagle feathers) in the
Ukko of the air struck fire,

Väinämöinen flashed

With three eagle's feathers, With five talons.

With three eagle's feathers, With five talons,

He struck the rock with a clang.

He made ready the fiery arrow

With narrow eagle feathers,

With sparrow talons.

Old Väinämöinen himself

Struck fire from his fingernails, Shook his limbs. 
verses mean an arrow. I further explained that viisi vipusinta or vivutsinta (five certain levers) refer to the five fingers needed to draw the bow when firing a fire arrow or lightning. But the verses may contain much more. First of all, there is the matter of striking fire from the claw. Leppäaho interprets this as follows: "Striking one's own nail and shaking one's $\operatorname{limb} \ldots$ probably means striking a flint. The small piece of flint between the finger tips really brings to mind that striking of nail" (Leppäaho 1949a, 87). The explanation is natural but nevertheless provokes the question whether it is a question of something reminiscent of a thunder bird. A further factor is whether the references to varpusen vivustimet, "the sparrow talon" in the verses quoted have been completely mixed up. A sparrow hardly fits in this context. Could it possibly be that what is meant are varpaat, "the toes' as the certain levers, the toes of the thunder bird? In order to solve these problems and the whole question of the thunder bird an detailed analysis of the verses is necessary.

This is probably the only possibility since Finnish archeological finds cast no light on the problem. Consequently, I can approach the question only from the perspective of the history of religion. Harva is almost certainly correct in assuming that it is a question of a deity in bird form that preceded the anthropomorphic god; the epithet air 'ilma' when referring to the bird indicates in the same way thundery weather as the connection with Ukko of the air. It is, then, a matter of a thunder bird characterised by stone claws.

It is not too far-fetched to believe that the eagle was looked upon as the bird of the air. The connection with an eagle is revealed in the verses quoted, kotkan sulista (eagle's feathers), if we can rely on the fact that context is not just random and simply explained by the arrow significance. More reliable evidence can be found from beyond Finnish frontiers. An Assyrian boundary stone has an eagle carved on it; the eagle is sitting on a column and reaching out towards a double fork of lightning striking the ground (Fig. 41) (Gray 1982, 22 ff.). The lightning, it is true, does not appear to emanate from the eagle but the connection between the two is nevertheless clear and the eagle can, with a fair degree of certainty, be interpreted as a thunder bird. The carving was probably made to mark the boundary with the eagle threatening to strike down with lightning anybody who dared to move the stone. The stone dates from the reign of Marduk-Nadin-Ahne, ca. 1102-1084 B.C. (Soden 1961-65, 62-9). At this late date the god of thunder was usually portrayed in human form in the Levant. However, it may be a question of an old stratum preserved in folk beliefs or of a god of thun- 


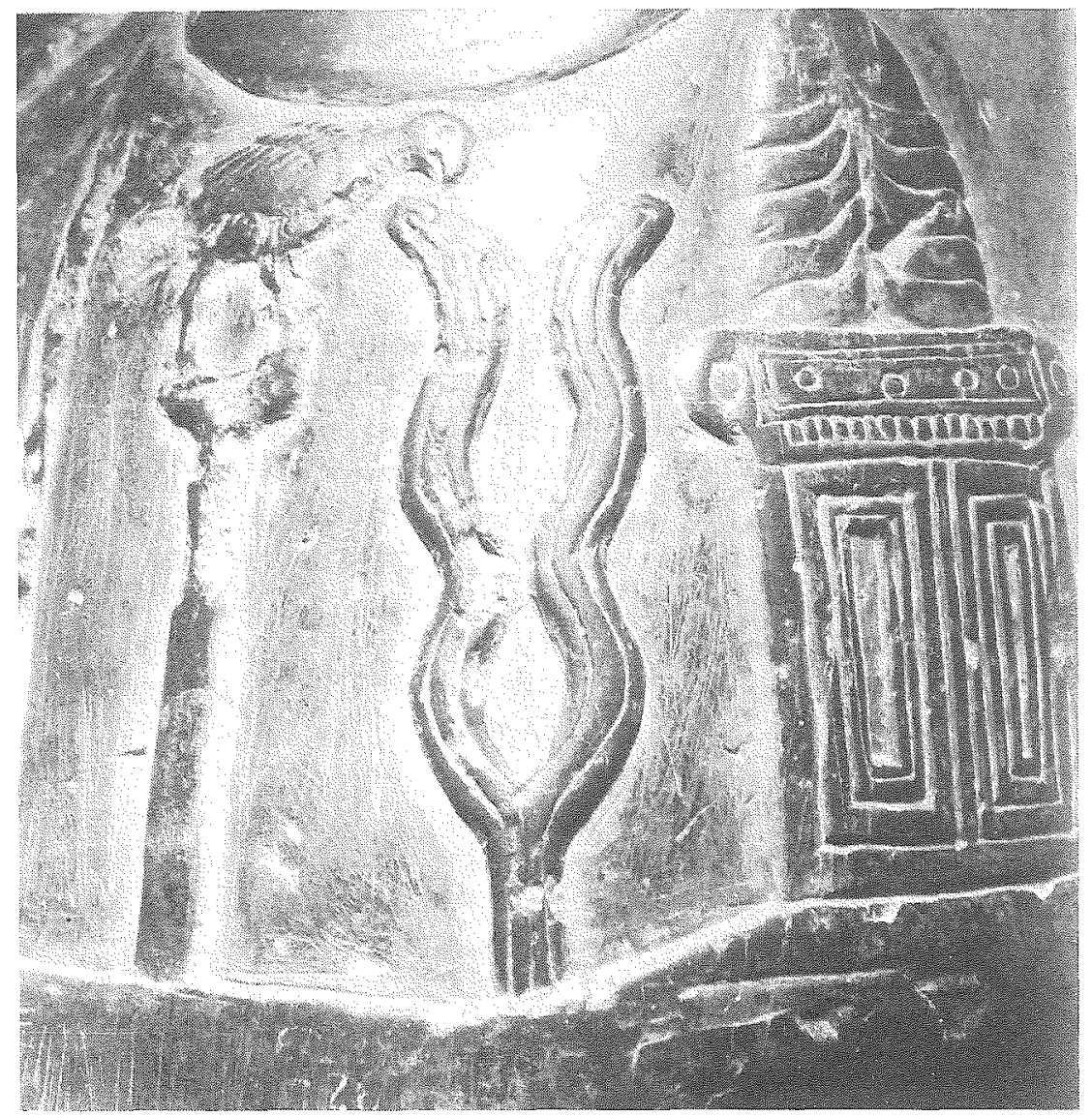

Fig. 41. Double fork of lightning of the Assyrian god of thunder, Adad, and beside it an eagle standing on a pillar, obviously a bird deity connected with thunder. Boundary stone from Marduk-nadin-ahne's time. (Gray 1982).

der that deviated from the usual. Such is known from the Romans.

There also exist references to the thunder eagle of the Indo-Europeans for the eagle was the bird of Zeus, Jupiter and Indra (Haavio 1961, $22)^{10}$. The eagle appears quite often in connection with Zeus both on

${ }^{10}$ It should be pointed out in this context that in the rock drawings from Lövås in Bohuslän (Glob 1971, 115) the battle axe god, doubtless the thunder god Thor, is depicted - to judge from the curved shape - as having a bird's head, presumably therefore that of an eagle. A bird's head in Scandinavian rock drawings is nevertheless a fairly common feature and not limited to the god of thunder, so there may perhaps be no reference to a thunder bird. 


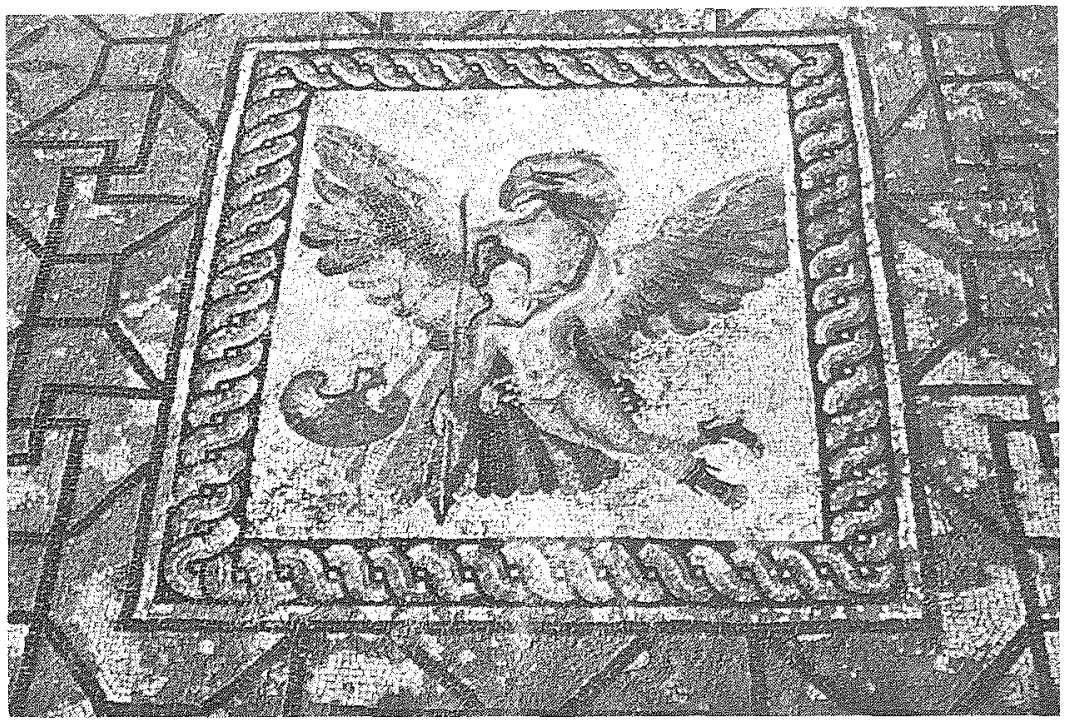

Fig. 42. Zeus' eagle bearing Ganymede to Olympus. Floor mosaic, clearly the finest representation of this theme from the house of Dionysos at Paphos, Cyprus. Mosaic dated second century A.D.

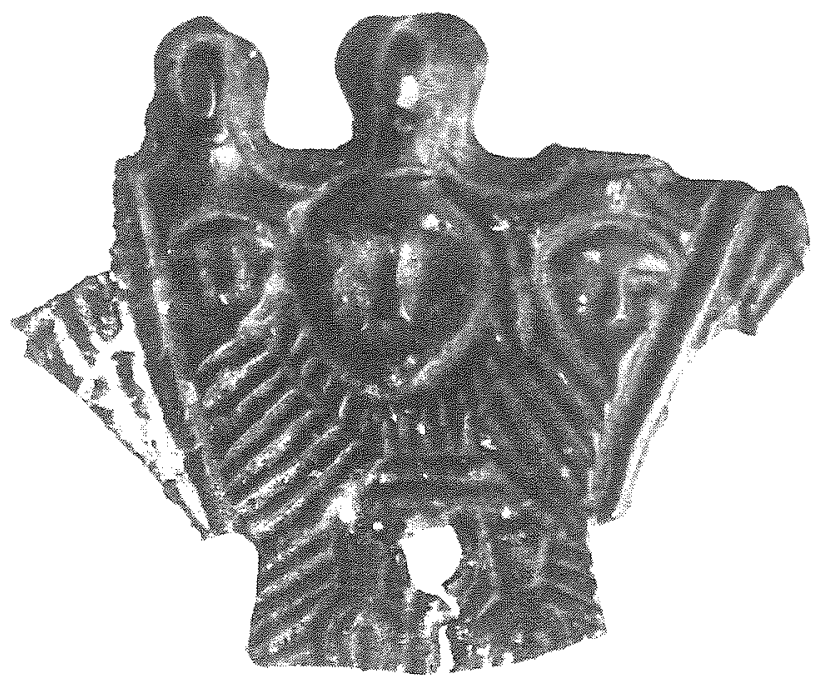

Fig. 43. Permian bronze ornament from Juupajoki. National Museum, Helsinki. Eagle and Ganymede theme shown on the ornament in triplicate in the tradition of Permian art. Only the face of Ganymedes is portrayed. Photo: E. Laakso, National Board of Antiquities. 


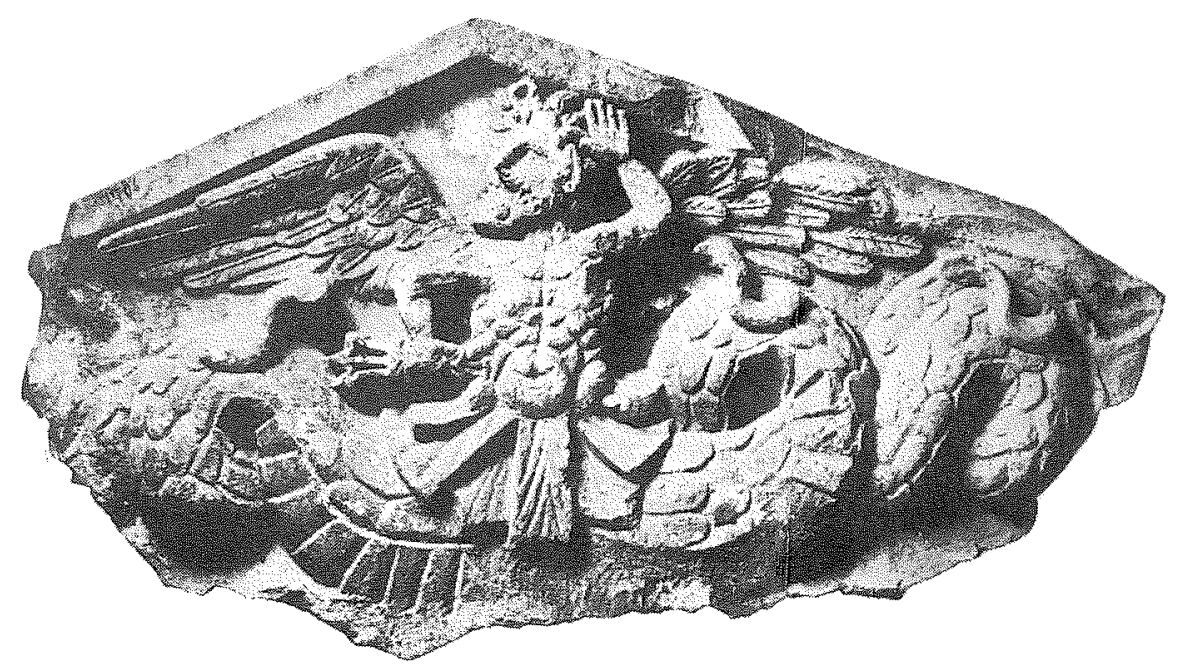

Fig. 44. Summanus, the Roman god of nightly thunder, portrayed as a combination of hum an being, bird and serpent, and holding a fork of lightning in the fashion of Jupiter. The original bird-shaped god of thunder in the form of Summanus seems to be united in part in an anthropomorphic god of thunder.

coins and vases, also in myths connected with Zeus although usually without any reference to lightning, it is true. Zeus' eagle carries the beautiful Ganymede to Olympus, for example, as shown in many ancient pictures ${ }^{11}$ (Fig. 42, 43) (Grant \& Hazel 1976, 153 ff.). The myth of Prometheus also places the eagle into some kind of relation to celestial fire. Prometheus stole fire from Olympus and brought it to man, so breaking with Zeus. The god chained Prometheus to a rock and sent an eagle to tear out his liver (Grant \& Hazel 1976, $346 \mathrm{ff}$.$) . Here, too, however, the link between eagle and lightning is$ very indirect, but quite clear in some symbols, where eagles, indeed, are carrying lightning (Cirlot 1988, $91 \mathrm{ff}$.). So the eagles of Jupiter can have lightning in their nails (Cooper 1986, 8-10). Jupiter's eagles were held in high esteem as symbols in imperial Rome and even earlier when

\footnotetext{
11 This motif extended as far as the Kama river in northern Russia and originated in Permian art. One of its products, an adornment in the shape of an eagle, has travelled as far as the Juupajoki in Häme (Kivikoski 1973, ill. 596). According to the manners in Permian art the eagle and Ganymedes are represented with three heads, Ganymede with just his face. Despite the fact that the wings are broken it is impossible to mistake the bird for anything other than an eagle. The adornment cannot be dated exactly; Kivikoski assigns it to articles of the Merovingian period.
} 
Jupiter was the protector and principal god of the realm (Perowne 1975, $17 \mathrm{ff}$.). The legions marched into battle carrying eagles, and it was a great disgrace if they were lost to the enemy. If Jupiter's eagles could probably be a loan from Zeus, however, and they do not have the same value as evidence of a god of thunder in bird shape.

Much more important in this context is that the Roman Summanus, the god of nocturnal thunder, seems clearly to have descended from the thunder bird (Fig. 44). Nocturnal lightning cannot be linked with Jupiter, the god of the bright sky, but was considered to have been sent by Summanus. Since Summanus does not correspond to Zeus, the iconography of the noble features of Greek representations of Zeus cannot be applied to him as they can to Jupiter. He is usually portrayed as an archaic monster with a human head, body and hands but with the wings of an eagle and a forked serpent's tail (Perowne $1975,36 \mathrm{f}$.). Here, then, we have a fusion of the god of thunder in human form, in snake form and in eagle form. As such Summanus fits well into the typology that began with portraying the thunder bird as an eagle and ended with an anthropomorphic god of thunder. I will return to the serpent theme later.

It is not entirely impossible that Thor, too, had a bird of prey associated with him in some cases. I refer to certain hammer pendants found in Skåne and at Hiddensee near Rügen; these are adorned with the head of a bird of prey, admittedly most probably that of a hawk. The pendants can be dated to the 10th and 11th centuries (Fig. 45) (Paulsen 1956, $210 \mathrm{ff}$.). The feature seems to be limited, however, both temporally and geographically, and can perhaps be explained as an influence from antiquity. It is in any case difficult to link it with traditional Thor mythology.

In the light of what has been said above the eagle of the IndoEuropean god of thunder goes back to an older thunder eagle preserved from the period when hunting culture still predominated, as revealed in hazy references in Finnish folk poems. If the thunder eagle was in fact the "oldest bird of the air", it is perhaps a question of the same mythical bird which in Finnish runes has a number of tasks. In the second poem of the Kalevala (II : 265-86) the eagle is presented as the igniter of the first clearing fire; this accords well with the history of the god of thunder and of agriculture in Finland. However, this is Elias Lönnrot's reconstruction since the verses he used did not originally include verses about cultivation but only runes concerning the origin of fire. In them it is not a eagle that strikes fire but Ukko (Kaukonen 1956 , verses $281-4$ ). 


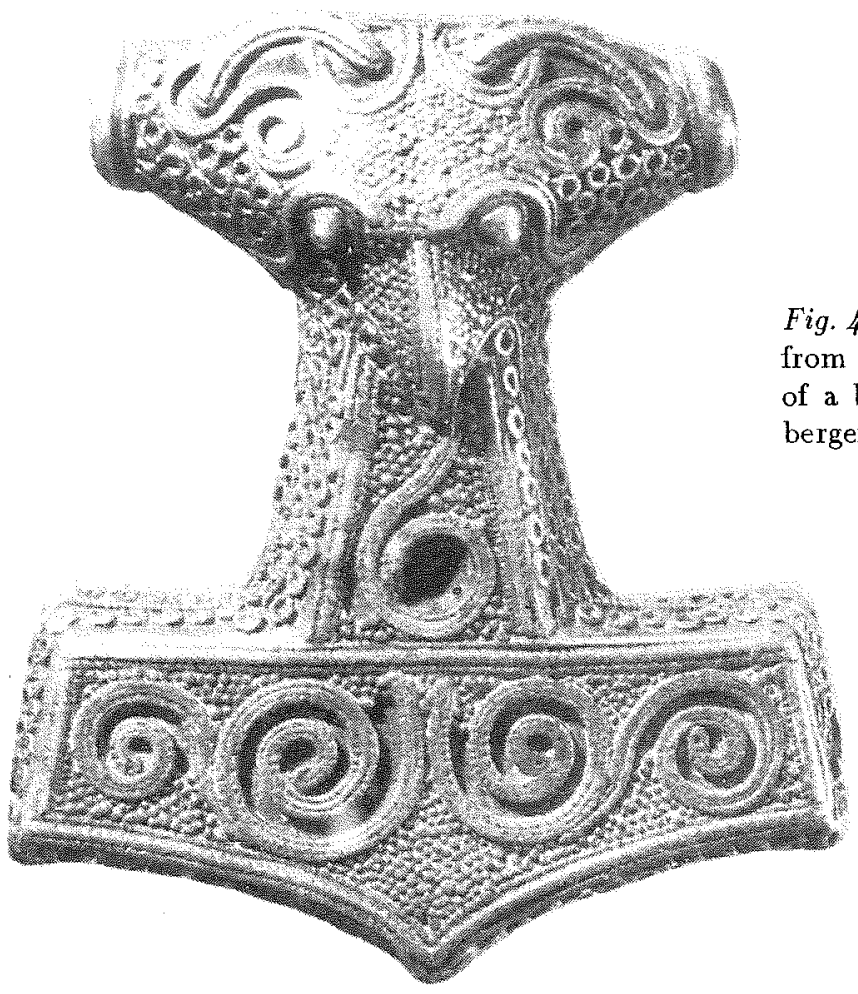

Fig. 45. A Thor's hammer from Skane with the head of a bird of prey. (Stenberger 1964).

Since folk tradition makes no mention of a bird's claw or nail but only of Ukko's nail, the deity in bird form has been obscured behind an anthropomorphic god. At first sight the idea of Ukko's stone nails does not seem to be any older than that of striking fire from a fire stone. There is no firm proof of striking fire in Finland until the Bronze Age; finds from the latter half of this period contain fire flints (Salo 1981, 301 f.). In this connection it may be asked whether the striking of fire cannot be an older feature since the word taula 'tinder' is of Baltic origin and, judging from its distribution, an early loan (Kalima 1936, 167; SKES 1246). But the word is not sufficient to prove for the taula was in fact used for making fire by friction, too. In my opinion we really need no proof of that, either, for lightning is so rapid a phenomenon that it invokes the concept of striking. The metaphor of striking fire can, then, be much older than the fire flints of the Bronze Age. And older it should be, as, too, the thunder bird. The thunder bird corresponds to the animal-like deities of the Stone 
Age, and it is in the Stone Age, according to the history of Ukko, that it should also belong.

\section{Snake lightning}

Jorma Leppäaho in his notable study notes, with reference to Kaarle Krohn that, judging from ancient runes, lightning was portrayed in the form of a serpent (Leppäaho 1949, 90-96). He quotes the verses:

Tulta iski ilma kaikki, Väinämöinen välkytteli Keskellä meri-kiviä, Kiiltävästä kärmehestä, (SKVR 11, 1773)
The entire air struck fire, Väinämöinen caused to flash Amid the sea-stones, From a shining serpent.

Instead of a shining serpent there often appears a multicoloured serpent. The serpent theme is known in Ingermanland, Savo, northern Karelia and along the border between Finland and Russia, in northern Häme and southern and northern Ostrobothnia. In the verses there is also sometimes reference to a black worm, a creeping worm of the earth, a burning worm of the earth. A crooked flash of lightning corresponds, of course, to the coils of a snake but Leppäaho also publishes a picture of lightning split into two lengthwise and so resembling a snake or serpent.

Nowadays a z-shaped angled line is used as a symbol of lightning. This obviously continues an ancient tradition which portrayed lightning as an angled or crooked line. Such an illustration of lightning is used in connection with Zeus' lightning, as on the 4th-century B.C. coin portraying Alexander the Great as Zeus or the Assyrian thunder eagle on the frontier stone, Fig. 13 and 41. The Assyrian god of storms is also portrayed holding a triple bunch of forked or crooked lightning (Gray 1982, 51).

Angled and wavy lines have been common forms of adornment since as far back as Paleolithic and Mesolithic times. Reference can be made, for example, to the angled decoration found on ball clubs and other shaft-hole weapons from Suomusjärvi culture (7000-4200 B.C.) (Edgren 1974). According to Edgren's assumption at least some of these clubs were made as cult objects; it is difficult to find any other explanation for them. Angled lines are also commonly found on Neolithic pottery, in Finland from early comb-ceramic times onwards. In most cases they are probably only decoration; even if there is 

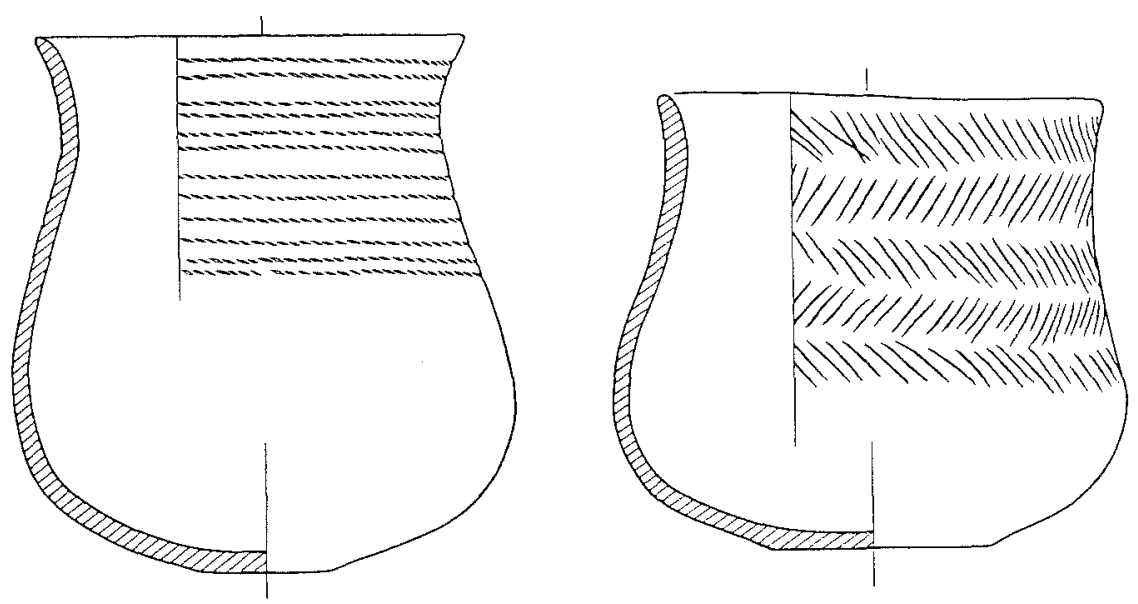

Fig. 46. Two cord-ceramic beakers from 1) Lieto, Finland Proper, and 2) Lempäälä, Satakunta. The cord decoration and the angel lines never appear on one and the same vessel, at least not in Finland. This follows perhaps from the symbolic character of the motifs. Drawn by Kristiina Korkeakoski-Väisänen after Edgren 1982.

some symbolism in them, there is scarcely sufficient evidence to make interpretation of it possible.

In some cases, however, the context indicates lightning, as for example on the Bronze Age shaft-hole axe found at Horozheno in the Ukraine, Fig. 35. Especially interesting in this respect are the Danish eye-goddess utensils, Fig. 31. Along their upper edge there are horizontal groups of angled lines or hanging triangles from which vertical angled lines, so to speak, "strike" in some cases downwards between the eyes. They may indicate lightning. The vertical decorations extending downwards from the eye figures are perhaps symbols of rain; certainly there are more of them elsewhere in the same ornamentation zone. This complex of motifs might be interpreted as the marriage of the god of thunder and his wife, the myth of the sky, clouds, thunder, rain and fruitfulness of the soil. I would point out that the eye decorations indicate that the objects served some cult purpose, that the eye pots date back to an early phase of agriculture in Danish prehistory and that agriculture was dependent on fire, water and soil, i.e. burning and clearing, rain and harvest.

No such motifs are to be found on Finnish Neolithic pottery objects. I pointed out above that the cord decorations of cord-ceramic and 
angled-line decorations never appear on the same beakers, at least in Finland (Fig. 46). Nonetheless, it is perhaps possible to assume on the basis of a grain-growing economy of battle-axe culture - there is no evidence of this in Finland - that the mutual exclusivity of these motifs might be explained by the symbolism of the Ukkonen deity and the mother deity. It may be asked whether the vertical angled lines could be symbols of lightning and thus of the god of thunder, could the cord decorations symbolize the mother goddess, Magna mater, alluding, maybe, to her girdle? It can be asked, but hardly answered. I can only say that the mutual exclusivity of these motifs needs an explanation, and add that that given above could be a probable one.

It is, however, possible to entertain justifiable evidence, at least to some extent, for the elliptical fire steels of the late Iron Age which in a way continue the symbolism of elliptical fire stones (Salo 1990). In some elliptical fire steels there are, within the frame, loops of thin wire forming a dense lace-like pattern. This would seem to be an obvious symbol of lightning in mediam rem. This interpretation is naturally based on context. According to Kivikoski (Kivikoski 1973, ill. 1009) such fire steels have been found at Mustalaismäki, Hattula, and Hiukkavainionmäki, Huittinen, both of them from the viking period. They are probably not of Finnish origin, for the same type is also known in Scandinavia, e.g. Birka (Arbman 1940, tab. 144:3a). Corresponding wavy-line decoration was also used on Viking tongueshaped and, later, other fire steels in Sweden and Norway (Keyland 1916, 208, ill. 10b-c, 218, ill. 17a). Mention should also be made of the fact that the handle of certain Norwegian fire steels is sometimes in wavy or serpent form (Keyland 1916, 212, ill. 13:28-9).

The thunder eagle on the Assyrian boundary stone, fig. 41 is portrayed with a double fork of lightning; the forks of lightning reach upwards from the ground. The same illustration is found, surprisingly, on pottery articles from Dnieper-Donetz culture, probably from the early part of the period, from the 5 th or 4 th millenium B.C. (Fig. 47) (Häusler 1966, 291; Sulimirski 1970, 86 f.; Siiriäinen 1973, 15 f.). It is found on the side of one object three times (Edgren 1982, fig. $22: 1$ ), and it is possible that this triple representation depends on the threefold so common in mythical connections. A task often only succeeds after being repeated three times. The similarity with the Assyrian representation of lightning is astounding and even though there is no eagle, the forks of the motif point towards the sky; they may indeed be lightning. The decorations may well refer to the importance of lightning and the rain that follows it and be indicative of a grain- 

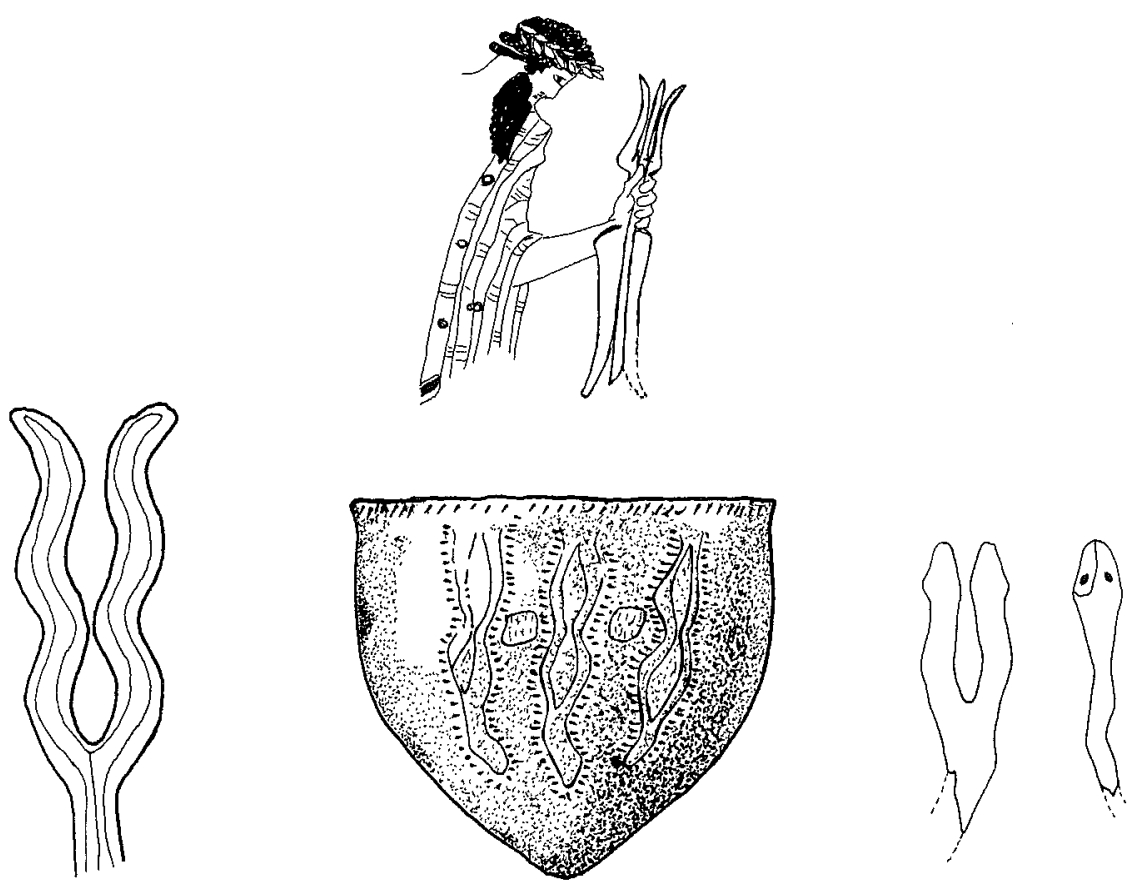

Fig. 47. In the lower row forked symbols of lightning. From left to right: a figure on a Mesopotamian boundary stone, a decoration on pottery of Dnieper-Donets culture, and a bone figure found at Tamula, Esthonia. The Tamula figure has two serpent heads, very similar to the head of the real serpent figure from Tamula, right in the lower row. Above Zeus with lightning, after a figure on a Greek 5th-century vase. Drawn by Kristiina Korkeakoski-Väisänen after Edgren 1982, Grant \& Hazel 1976, Gray 1982, Jaanits 1957.

growing economy or at least contacts with agricultural economies. According well with the lightning interpretation is also the fact that the bunches of forked lightning of Zeus and the thunder deities of the Levant can be derived from the double fork of lightning symbol, fig. 47. For this a third fork of lightning has to be added between the existing double fork; here we can refer to the illustration on a 5th-century vase in which the outer forks of lightning held by Zeus are rather similar to those described above (Fig. 47) (Grant \& Hazel 1976, ill. p. 153). However, I cannot go into the origin of Zeus' lightning symbol in more detail here; it probably goes far back into Neolithic time.

The symbol of the double fork of lightning is brought near to Finland, or at least seems to have been brought, by a fragmentary double- 


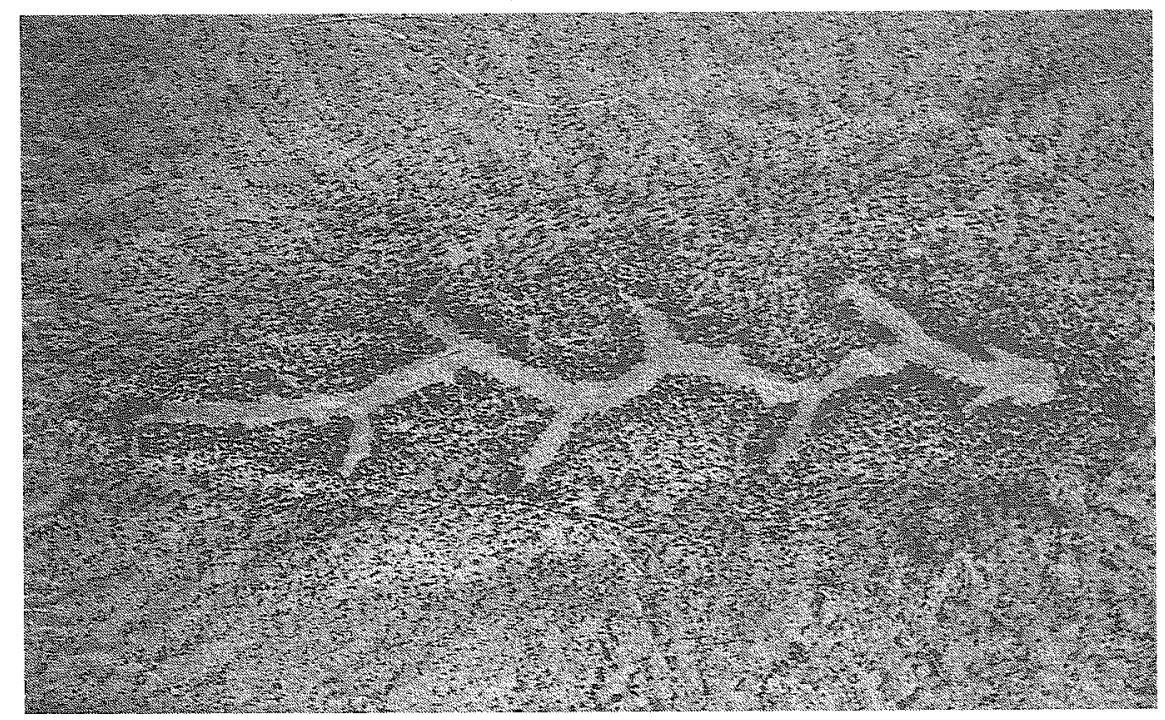

Fig. 48. Serpent figure on the Peri Nos cliff on the eastern shore of Lake Onega. The serpent is formed of an angled line which continues in two parts upwards and of a broad triangular head recalling a sharp-pointed arrow. These abnormal characteristics suggest lightning in the form of a serpent.

headed bone design from Tamula, Estonia, (Fig. 47) (Jaanits 1957, ill. $4: 20)$. It is very reminiscent of the pottery decorations referred to earlier. However, it differs from these in that the double fork of lightning seems to be transformed into a double-headed serpent. The heads of the serpent are rather similar to the serpent figure of the same burial ground, (Fig. 47) (Jaanits 1957, ill. 4:10); its necks are portrayed in snake form and even the "body" seems to continue as an angled line. The former object is a find from a woman's grave and has been dated to late comb-ceramic times, the latter half of the 3rd millenium B.C. (Jaanits 1957; Meinander 1984a, 38). This possibly provides a bridge for the serpent-lightning in Finnish myths of the origin of fire; the Tamula design could be interpreted as the forerunner of these. If this interpretation is correct, then the early proto-Finnish heritage of late comb-ceramic times lives in the lightning serpents of spells. It is possible, of course, that it goes back even farther.

The proof of this provided, in my opinion, by the serpent drawings on the rocks of Peri Nos, a promontory in Lake Onega in Russian Karelia (Fig. 48). The protuberant "hooks" or "thorns" of the angular 
lines of the serpent bodies and the head in the shape of an arrow tip are an unnatural feature and seem to indicate that the figures does not portray a real serpent but a serpent as a symbol of lightning. In this connection I would point to the similar protuberances of the lightning image on the 4th-century Greek coin (Fig. 13), even though the similarity is no conclusive proof, of course. According to Russian archeologists, the rock drawings on Lake Onega belong to Pitcomb ware culture and thus probably to a Fenno-Ugrian people. They have been dated to the 5 th or 4 th millenium B.C. ${ }^{12}$

The double-forked nature of lightning and the lightning serpent, attested to by the Tamula figure and similar lightning designs, does not appear in spells. But it has a surprising equivalent in the double serpent of Summanus' tail (Fig. 44). If this is a primary feature of Summans' iconography, then double-forked lightning was apparently given living form as a twin serpent as early as Indo-European times. This feature need not neccessarily be genuine, however; it could as well be explained as a loan from Greek iconography. Triton in Greek mythology was characterised by a split serpent's tail as early as the 6th century B.C. (Grant \& Hazel 1976, 408). The giants, the children of Gaia, the mother Earth, had serpent legs, as shown in numerous illustrations (Grant \& Hazel 1976, 154-61). These serpent legs are probably evidence of the earthly origin of the giants, gegeneis, and are probably unconnected with serpent lightning, even though the giants were the opponents of Zeus (and other gods).

\section{Conclusions}

What has been said above can be summed up in the following theses and hypotheses:

1. Finnish epic poetry has preserved dim memories of a thunder bird, a deity known among the hunting peoples of Siberia and northern America. It had stone nails with which it struck lightning and when it flew, it created a mighty rumbling sound. The thunder bird lived on as the eagles of the Indo-European thunder gods, and it is conceived of as an eagle here, too. If the eagle in question was the great mythical bird of Finnish epics, as I assume, then it also had other tasks. It may well go back to pre-agricultural times, to the Stone Age, where it fits in well with the animal deities of that period.

\footnotetext{
12 The author had an opportunity to study the rock drawings of Lake Onega in July 1989.
} 
2. Finnish runes about the origin of fire have also preserved the idea of lightning portrayed as a serpent. Serpent-lightning probably goes back to early proto-Finnish times, the latter half of the 3rd millenium B.C., perhaps even farther, and was linked with the animal deities of the Stone Age. Iconographically it seems to continue the doubleforked lightning symbols apparently known even in the 5th and 4th millenia B.C. From it there seems to derive another trend leading to the lightning held by Zeus and Levant gods of thunder.

3. The Indo-European god of the sky/god of thunder goes back to proto-Indo-European times, at the latest to the 3rd millenium B.C. but probably even earlier. His weapon was a hammer or battle axe, a shaft-hole axe. Consequently, this god must have existed or originated during the period such axes were in use, ca. 3300/3000-500/400 B.C. Stone axes, it would seem, made their appearance north of the Danube in central and northern Europe, the area of funnel-beaker culture, at the end of the 4th or beginning of the 3rd millenium B.C. The patriarchal nature reflected in the marriage relationship between the god of the sky and Magna Mater corresponds to the social structure of the funnel-beaker and battle-axe cultures since no clay idols connected with mother goddesses are known in the area concerned as they are in southeastern and southern Europe. The emphasis on man's status is also reflected in the hammer axes and perhaps in burial customs of the period. At the beginning of the 3rd millenium B.C. the worship of a mother goddess/death goddess spread from the Atlantic seaboard of Europe to the funnel-beaker people. However, it gave way rather rapidly to battle-axe culture and apparently to worship of a god of the sky/god of thunder.

4. The Indo-European god of thunder, who had no proto-IndoEuropean name, evolved from a god of the sky at the latest during the 3rd millenium B.C., evidently during the battle-axe period. The god of thunder reigned over lightning and rain, i.e. fire and water, central elements in a clearing and burning economy. The stone shaft-hole axes of the Bronze Age, which had become old-fashioned as weapons, seem to have been manufactured for the god of thunder. Earlier battle-axes cannot be shown to have been the special cult weapons of the god of thunder although they may have been his emblems. In Scandinavian rock drawings the god of thunder goes back to the Bronze Age, and in Lithuania a bronze image of a Hurritic god of thunder has been found which dates back to the early Bronze Age. The human-headed club found at Kiuruvesi, apparently from the Kiukais period, can also probably be explained as a cult object of the god of thunder. This 
human head is probably one of the oldest representations of the god of thunder in northern Europe.

5. The Indo-European god of thunder became known in Finland perhaps during the time of battle-axe culture as taivas 'sky' was borrowed from proto-Baltic. However, the god of the sky probably did not serve any particular purpose during late comb-ceramic times when the economy was still based on hunting and fishing. It may have been connected from the very beginning with the Kiukais period (2000-1400/1200 B.C.), however, when agriculture became important in the economy. During Kiukais times shaft-hole axes, weapons of agriculture society, were imported and made as weapons but perhaps for cult purposes, too, but so also were the bear-head and elk-head clubs and axes characteristic of a hunting economy. From this it may be concluded that it was a time of both the old animal-shaped gods of the Stone Age and the new anthropomorphic god of thunder. Since the god of thunder went by the name Ukko, which points to a possible eastern Finnish origin, throughout the whole of the country, it is possible that Ukko came to western Finland from the direction of Karelia, probably with a wave of Sarsa ceramic immigration at about the middle of the 2nd millenium B.C. Some of the oldest protoFinnish terms in agriculture and cattle raising also came from the same direction so that both may have arrived with the same textile-ceramic current, if not the first textile-ceramic phase at the beginning of the millenium. At the beginning of the Bronze Age, after the iniddle of the millenium, there arrived on the western and southern coasts of Finland a Scandinavian god of thunder. The two thunder deities merged with each other and Ukko adopted myths and attributes, albeit not all of them, of the new western god of thunder, starting with the shafthole axes that came from the west (and south). He also preserved his early proto-Finnish name. From the shaft-hole axes it appears that this anthropomorphic god of thunder spread to the centre of the country to join the Saame deities. During the Bronze Age it seems to have thrust aside the animal deities of the hunting era in most of the southern and central parts of Finland.

6. Ukko spread to Finland as the god of the burning and clearing economy and peasant society. His functions included assuring the fertility of the soil, the growth of the crops and the yearly harvest. This took place in the holy marriage of Ukko and his spouse: in flashes of lightning, the rumble of thunder and thundery rain. Ukko may have celebrated such holy marriages from his very arrival but no firm evidence of them appears until the Iron Age with the coming of 
elliptical fire stones (ca. 50-700) and the elliptical rimmed fire steels that followed them. Since the use of these continued from Merovingian times (550-800) until the advent of matches it is understandable that the hieros gamos myth was still a living folk belief during Agricola's time. Similar beliefs were also preserved among the Swedish-speaking population of Ostrobothnia until recent times, apparently as a tradition going back to their medieval arrival in Finland. The symbolic shapes of the fire stones and fire steels indicate that the secular striking of fire was looked upon as a rite repeating the myth of the origin of celestial fire. Elliptical fire stones were probably associated primarily with clearing and burning and indicate, partly at least, the geographical extent of this economy. Fire stones were apparently used in sacrifices to show what was expected of Ukko. Ukko, like Thor, had the general duties of a father god but they are not discussed in this context.

7. The bow and lyre fire steels of Merovingian times are explained by the myth of the origin of fire told in ancient epics. In these Ukko of the sky fires a fire arrow, i.e. lightning, from his bow. The myth may derive from Asia but the bow and lyre fire steels seem to indicate that the myth extended over the whole continent of Europe. The myth together with Ukko's bow and arrow formed part of common belief among the people during the viking era and after it right up to late historical time. However, it has not succeeded in replacing the hieros gamos myth. Is this evidence of a myth of hunting people in particular?

8. The international notion of stone thunderbolts does not seem to have been current in Finland until the Iron Age when the use of stone to make cutting edges had been forgotten. Nails did not begin to be used until the beginning of the present chronological era; this probably places a temporal limit for the term thunder nail. Thunder nail, however, is probably based on a mistranslation of the protoScandinavian or early Swedish naghl 'fingernail' as 'nail'. Ukko's cloak cannot philologically be older than the Viking period but the history of of the garment itself goes back much further in time. Viking finds on Aland include Swedish rings with Thor's hammers hanging on them but such pendants do not seem to have been used on the Finnish mainland, as was previously believed.

9. The author agrees with Martti Haavio's view that Rauni was not the name of Ukko's spouse but an epithet for Ukko himself. But even as an epithet for Ukko it does not seem to derive from genuine folk tradition but may well be Mikael Agricola's corruption of the Latin or 
Greek. With this epithet, the significance of which remains unknown, Agricola may have been trying to incorporate the idea that the Finnish Ukko was the parallel of the Zeus Keraunios of the Greeks.

10. Perkele, 'the enemy of the soul', in the Finnish language and its Balto-Fennic equivalents are probably derived philologically from Perkunas, the name of the Baltic god of thunder. Since their only meaning in Balto-Fennic dialects, however, is 'enemy of the soul', 'hell', they may well not have been absorbed until the early stages of Christianity when a name was needed to personify evil. Such a personality was not included in the heathen terminology of the BaltoFennic peoples.

\section{Bibliography}

Ailio, J. 1909. Die steinzeitlichen Wohnplatzfunde in Finnland 1-2. Helsingfors.

Alhonen, P. 1970. En pollenanalytisk undersökning vid stenåldersboplatsen Perkiö i Hauho socken, Södra Finland. Suomen Muinaismuistoyhdistyksen Aikakauskirja/Finska Fornminnesföreningens Tidskrift 72. Helsinki.

Almgren, B. 1962. Den osynlige gudomen. Proxima Thule. Stockholm.

Almqvist, B. 1956-78. Torvigg. Kulturhistoriskt lexikon för nordisk medeltid 18. Helsingfors

Arbman, H. 1940. Birka 1. Die Gräber. Tafeln. Uppsala.

Baudou, E. 1960. Die regionale und chronologische Einteilung der jüngeren Bronzezeit im Nordischen Kreis. (Acta Universitatis Stockholmiensis. Studies in North-European Archaeology 1.) Stockholm.

Becker, C. J. 1969. Trichterbecherkultur. Enzyklopädisches Handbuch zur Urund Frühgeschichte Europas 2. Hrsg. von J. Filip. Prag.

Bezzenberger, A. \& Peiser, F. E. 1909. Die Bronzefigur von Schernen, Kr. Memel. Prussia 22, 1900-1904. Königsberg.

Brøndsted, J. 1938-39. Danmarks Oldtid 1-2. København.

- 1961-62. Nordische Vorzeit 1-2. Neumünster.

Buchvaldek, M. 1969. Schnurkeramische Kulturen. Enzyklopädisches Handbuch zur Ur- und Frühgeschichte Europas 2. Hrsg. von J. Filip. Prag.

Carpelan, Chr. 1974. Hirven- ja karhunpääesineitä Skandinaviasta Uralille. Suomen Museo. Helsinki.

- 1975. Älg- och björnhuvudföremål från Europas nordliga delar. Finskt Museum. Helsingfors.

Cirlot, J. E. 1988. A dictionary of symbols. London.

Cleve, N. 1943. Skelettgravfälten på Kjuloholm i Kjulo. Suomen Muinaismuistoyhdistyksen Aikakauskirja/Finska Fornminnesföreningens Tidskrift 64. Helsinki. 
Cooper, J. C. 1986. Illustriertes Lexikon der traditionellen Symbole. Leipzig. Davaras, C. 1976. Guide to Cretan antiquities. New Jersey.

Dechelette, J. 1908-14. Manuel d'archéologie préhistorique celtique et galloromain 1-2. Paris.

Donner. 1966-81. Brockhaus Enzyklopädie 5. Wiesbaden.

Edgren, T. 1970. Studier över den snörkeramiska kulturens keramik i Finland. Suomen Muinaismuistoyhdistyksen Aikakauskirja/Finska Fornminnesföreningens Tidskrift 72. Helsinki.

- 1974. De ristade klubbhuvudena av sten och deras datering. Finskt $M u$ seum. Helsingfors.

- 1982. Formgivning och funktion. Iskos 3. Helsinki.

- 1984a. Kivikausi. Suomen esihistoria 1. Espoo.

- 1984b. On the economy and substance of the battle-axe culture in Finland. (Fenno-ugri et Slavi 1983.) Iskos 4. Helsinki.

Feldhaus, F. M. 1914. Die Technik der Vorzeit, der geschichtlichen Zeit und der Naturvölker. Leipzig.

Filip, J. 1969. Enzyklopädisches Handbuch zur Ur- und Frühgeschichte Europas 2 . Prag.

Frisk, H. 1960. Griechisches etymologisches Wörterbuch 1. Heidelberg.

Gelling, P. \& Ellis Davidson, H. 1969. The chariot of the sun and other rites and symbols of the Northern Bronze Age. London.

Glob, P. V. 1938. Stenredskaber fra Bronzealderen. Winther-Festskrift. København.

- 1971. Högarnas folk. København.

Grant, M. \& Hazel, J. 1973. Lexikon der antiken Mythen und Gestalten. München.

Graudonis, J. 1967. Latvija v epohy pozdnei bronzy i rannego zeleza. Riga.

Gray, J. 1982. Near Eastern Mythology. (Library of the world's myths and legends.) London.

Haavio, M. 1959. Karjalan jumalat. Porvoo.

- 1961. Ukko ylijumala. Kalevalaseuran vuosikirja 41. Helsinki.

Hackman, A. 1905. Die ältere Eisenzeit in Finnland. 1. Helsingfors.

Harva, U. 1943. Sammon ryöstö. Porvoo.

- 1948. Suomalaisten muinaisusko. Porvoo.

Hasselrot, P. \& Ohlmarks, A. 1966. Hällristningar. Stockholm.

Heikkurinen, T. \& Suominen, E. 1982. Karjaan Hagnäs II:n ja Östergårdin kaivaukset. Studia minora 29. (Helsingin yliopiston arkeologian laitos. Moniste 29.) Helsinki.

Heininen, S. 1976. Nuori Mikael Agricola. (Suomi 120, 3.) Helsinki.

Hellquist, E. 1980. Svensk etymologisk ordbok 1-2. Lund.

Hiller, S. 1978. Zeus 2. A. Sprachgeschichte und mykenische Belege. Paulys Realencyclopädie der classischen Altertums Suppl. 15. München.

Huurre, M. 1983. Pohjois-Pohjanmaan ja Lapin esihistoria. Pohjois-Pohjanmaan ja Lapin historia 1. Kuusamo. 
Häusler, A. 1966. Dnepr-Donec-Kultur. Enzyklopädisches Handbuch zur Urund Frühgeschichte Europas 1. Von J. Filip. Prag.

Jaakkola, J. 1935. Suomen varhaishistoria. Suomen historia 2. Porvoo.

Jaanits, L. 1957. Neue Gräberfunde auf dem spätneolitischen Wohnplatz Tamula in Estland. Suomen Muinaismuistoyhdistyksen Aikakauskirja/ Finska Fornminnesföreningens Tidskrift 58. Helsinki.

- 1982. Noorem kiviaeg. Eesti esiajalugu. Tallinn.

Jazdzewski, K. 1965. Poland. London.

Jensen, J. 1982. The prehistory of Danmark. New York.

Kaelas, L. 1957. De dubbeleggade yxorna i Sverige. Suomen Muinaismuistoyhdistyksen Aikakauskirja/Finska Fornminnesföreningens Tidskrift 58. Helsinki.

- 1962. Stenkammargravar i Sverige och deras europeiska bakgrund. Proxima Thule. Stockholm.

- 1966. The megalithic tombs in South Scandinavia - migration or cultural influence. Paleohistoria 12, Groningen.

Kalima, J. 1936. Itämerensuomalaisten kielten balttilaiset lainasanat. ( Suomalaisen Kirjallisuuden Seuran toimituksia 202.) Helsinki.

Kaukonen, V. 1956. Elias Lönnrotin Kalevalan toinen painos. (Suomalaisen Kirjallisuuden Seuran toimituksia 247.) Helsinki.

Keyland, N. 1916. Primitiva eldgörningsmetoder i Sverige. Fataburen. Stockholm.

Kirkinen, S. 1967. Oliko Sampsa historiallinen henkilö?. Kalevalaseuran vuosikirja 47. Helsinki

Kivikoski, E. 1937. Suomen vanhinta rautakautta. Suomen Museo. Helsinki.

- 1961. Suomen esihistoria. Suomen historia 1. [Ed. by] J. Jaakkola. Helsinki.

- 1973. Die Eisenzeit Finnlands. Helsinki.

Klindt-Jensen, O. 1975. A history of Scandinavian archaeology. London.

Koivulehto, J. 1973. Germanisch-Finnische Lehnbeziehungen 3. Neuphilologische Mitteilungen 4. Helsinki.

- 1979. Phonotaktik als Wegweiser in der Lehnwortforschung: fie osfi. -strWörter. (Finnisch-ugrische Forschungen 43.) Helsinki.

- 1983a. Seit wamn leben die Urfinnen im Ostseeraum? Suomalais-Ugrilaisen Seuran toimituksia 125 . Helsinki.

- 1983b. Suomalaisten maah anmuutto indoeurooppalaisten lainasanojen valossa. Suomalais-Ugrilaisen Seuran aikakauskirja 78. Helsinki.

Kostrzewska, M. 1953. Wyroby kamienne kultury luzyckiej w Wielkopolsce brazowej $\mathrm{i}$ wczesnozelaznej. Les outils en pierre de la civilisation lusacienne de lage du bronze et du premier age du fer en Grande Pologne. Przeglad archeologiczny. Poznan.

Kostrzewski, J. 1919. Die ostgermanische Kultur der Spätlatènezeit. (ManusBibliothek 18). Leipzig.

- 1955. Wielkopolska w pradziejacl. Warszawa. 
Krohn, K. 1914. Suomalaisten runojen uskonto. (Suomensuvun uskonnot 1.). Porvoo.

- 1917. Suomalaiset syntyloitsut. (Suomalaisen Kirjallisuuden Seuran toimituksia 157.) Helsinki.

Kulikauskas, P. \& Kulikauskiene, R. \& Tautavicius, A. 1961. Lietuvos archeologijos bruozai. Vilnius.

Lehtosalo-Hilander, P.-L. 1982. Luistari 2. Suomen Muinaismuistoyhdistyksen Aikakauskirja/Finska Fornminnesföreningens Tidskrift 82:2. Helsinki.

- 1988. Esihistorian vuosituhannet Savon alueella. Savon historia 1. Kuopio.

Leppäaho, J. 1949a. Iski tulta ... Kalevalaseuran vuosikirja 29. Helsinki.

- 1949b. Viikinkiaika (N. 800-1050). Suomen historian käsikirja 1. Porvoo.

Leube, A. 1975. Die römische Kaiserzeit im Oder-Spree-Gebiet (Veröffentlichungen des Museums für Ur- und Frühgeschichte Potsdam. Berlin.

Lindqvist, Ch. 1988. A carbonized grain (Hordeurn sp.) and faunal remains of e.g. Harp Seal (Phoca groenlandica), Cod (Codhus morhua) and Herring (Clupea harengus) from the Kolsvidja upper stone age habitation site on Aland. Finskt Museum. Helsingfors.

Löugas, V. 1982. Pronksiaeg. Eesti esiajalugu. [By] L. Jaanits et al. Tallinn. MacCana, P. 1970. Celtic Mythologi. London.

Meinander, C. F. 1939. Pyheensilta stenåldersplats. Finskt Museum. Helsingfors.

- 1954a. Die Kiukaiskultur. Suomen Muinaismuistoyhdistyksen Aikakauskirja/Finska Fornminnesföreningens Tidskrift 53. Helsinki.

- 1954b. Die Bronzezeit in Finnland. Suomen Muinaismuistoyhdistyksen Aikakauskirja/Finska Fornminnesföreningens Tidskrift 54. Helsinki.

- 1969. Dåvits. Finskt Museum. Helsingfors.

- 1984. Kivikautemme väestöhistoria. Suomen väestön esihistorialliset juuret. (Bidrag till kännedom av Finlands natur och folk 131.) Helsingfors.

Milisauskas, S. 1973. European prehistory. New York.

Moora, H. 1938. Die Eisenzeit in Lettland bis etwa 500 n. Chr. 2. (Verhandlungen der Gelehrten Estnischen Gesellschaft 29.) Tartu.

- 1958. Zur etnischen Geschichte der ostseefinnischen Stämme. Suomen Muinaismuistoyhdistyksen Aikakauskirja/Finska Fornminnesföreningens Tidskrift 59, 3. Helsinki.

Moreau, J. 1958. Die Welt der Kelten. Grosse Kulturen der Frühzeiten. Stuttgart.

Nordman, C. A. 1942. Schatzfunde und Handelsverbindungen in Finnlands Vikingerzeit. (Acta Archaeologica 13.) København.

Nuñetz, M. G. 1986. Clay figurines from the Åland Islands and mainland Finland. Fennoscandia Archaeologica 3. Helsinki.

Ohlmarks, A. 1975. Fornnordisk ordbok. Kristianstad.

Okulicz, J. 1973. Pradzieje ziem pruskich od poznego paleolitu do VII w. n. e. Wroclaw. 
Paulsen, P. 1956. Axt und Kreutz in Nord- und Osteuropa. Bonn.

Perowne, S. 1975. Roman mythology. London.

Piggott, S. 1965. Ancient Europe from the beginnings of agriculture to Classical Antiquity. Edinburg.

Pihlman, S. \& Seppä-Heikka, M. 1985. Indication of Late-Neolithic cereal cultivation of the Kotirinne dwelling site at Niuskala, Turku, SW Finland. (Memoranda Soc. Fauna Flora Fennica 61.) Helsinki.

Pittioni, R. 1949. Die urgeschichtlichen Grundlagen der Europäischen Kultur. Wien.

Riordain, S. P. \& Daniel, G. 1964. New Grange and the Bend of Boyne. London.

Rodden, J. 1981. The development of Tree Age System: Archaeology's first paradigm. Towards a history of archaeology. Ed. by G. Daniel. London.

Rydh, H. 1917. S.k. eldslagningsstenar från järnåldern. Fornvännen. Stockholm.

Salmo, H. 1957. Ein neuentdecktes römerzeitliches Gräberfeld in Südwestfinnland. Finskt Museum. Helsingfors.

Salo, U. 1968. Die frührömische Zeit in Finnland. Suomen Muinaismuistoyhdistyksen Aikakauskirja/Finska Fornminnesföreningens Tidskrift 67. Helsinki.

- 1970. Muinaisjäännökset ja muinaislöydöt. Metallikautinen asutus Kokemäenjoen suussa. 1. [Ed. by] U. Salo \& P. Lahtiperä. Pori.

- 1981. Satakunnan pronssikausi. Satakunnan historia 1, 2. Rauma.

- 1984a. Pronssikausi ja rautakauden alku. Suomen historia 1. Espoo.

- 1984b. Esihistoriallinen asutuksen jatkuvuudesta Suomen rannikolla. Suomen väestön esihistorialliset juuret. (Bidrag till kännedom av Finlands natur och folk 131.) Helsinki.

- 1984c. Pyyntikulttuurista maan viljelyyn. Sukupolvien perintö 1. Helsinki.

- 1987. Suomen kristillistymisen varhaisvaiheista. Studia historica in honorem Vilho Niitemaa. (Turun historiallinen arkisto 42.) Turku.

- 1988. Kontakter tvärs över Bottenviken under förhistorisk tid. Iskos 7. Helsinki.

- 1990. Rautakautiset tulentekovälineet ja suomalaiset tulensyntymyyttit. Iskos 8. Helsinki.

Schwabl, H. 1972. Zeus 1. Paulys Realencyclopädie der classischen Altertumswissenschaft X A. München.

- 1978. Zeus 2. Paulys Realencyclopädie der classischen Altertumswissenschaft Suppl. XV. München.

Setälä, E. N. 1910. Ukko, "hattaroiden hallitsija". Finnisch-Ugrische Forschungen 10.) Helsingfors.

- 1912. Aus dem Gebiet der Lehnbeziehungen. (Finnisch-Ugrische Forschungen 13.) Helsingfors.

Siiriäinen, A. 1969. Uber die Chronologie der steinzeitlichen Küstenwohn Finnlands im Lichte der Uferverschiebung. Suomen Museo. Helsinki. 
Siiriäinen, A. 1972. A gradient/time curve for dating Stone Age shorelines in Finland. Suomen Museo. Helsinki.

- 1973. Studies relating to shore displacement and Stone Age chronology in Finland. Finskt Museum. Helsingfors.

- 1982. Recent studies on the Stone Age economy in Finland. Fennoscandia antiqua 1. Helsinki.

Sirelius, U. T. 1921. Suomen kansanomaista kulttuuria 2. Helsinki.

Sjövold, T. 1962. The Iron Age settlement of Arctic Norway. (Tromsø Museums skrifter 10,1) Troms $\varnothing$.

SKES Toivonen, Y. H. et al. 1955-81. Suomen kielen etymologinen sanakirja 1-7. (Lexica Societatis Fenno-Ugricae 12, 1-7.) Helsinki.

SKVR Suomen kansan vanhat runot 1-14. 1908-14. (Suomalaisen Kirjallisuuden Seuran toimituksia 121-151.) Helsinki.

Soden, W. v. 1961-65. Der Nahe Osten im Altertum. Propyläen Weltgeschichte 2. Berlin.

Soikkeli, K. 1912. Suippokantaiset kohoteräiset kirveemme. Suomen Muinaismuistoyhdistyksen Aikakauskirja 26. Helsinki.

Stenberger, M. 1964. Det forntida Sverige. Stockholm.

Streng, A. V. 1975. Latinalais-suomalainen sanakirja. (Suomalaisen Kirjallisuuden Seuran toimituksia 196.) Helsinki.

Ström, K. 1956-78. Torshamrar. Kulturhistoriskt lexikon för nordisk medeltid 18. Helsingfors.

Strömberg, M. 1981. Järn i österlenska forntidsfynd. Simrishamn.

Suhonen, S. 1984. Lainasanat balttilais-itämerensuomalaisten kontaktien kuvastajina. (Bidrag till kännedom av Finlands natur och folk 131.) Helsinki.

Sulimirski, T. 1970. Prehistoric Russia. New York.

Tallgren, A. M. 1926. La pontide prescythique apres l'introduction des metaux. Eurasia septerionalis antiqua 2. Helsinki.

- 1938. A bronze statuette from Lithuania. Senatne un maksla 2. Riga.

Tarkiainen, V. 1945. Mikael Agricolan opiskelu Wittenbergissä. Suomalaisen Tiedeakatemian Esitelmät ja Pöytäkirjat 1945. Helsinki.

Tatton-Brown, V. 1984. The archaic period. Footprints in Cyprus. Ed. by D. Hunt. London.

Thulin, [C. O.]. 1917. Iuppiter. Paulys Real-Encyclopädie der classischen Altertumswissenschaft X. Stuttgart.

Tönisson, E. 1982. Keskmine rauaaeg. Eesti esiajalugu. [By] L. Jaanits et al. Tallinn.

Valonen, N. 1944. Sämpsä ja sämpsänmätäs. Kalevalaseuran vuosikirja 2324. Porvoo.

Vikkula, A. 1984. Pyheensilta ceramics - facts and theories. Iskos 4. Helsinki.

Vries, J. de 1956-57. Altgermanische Religionsgeschichte 1-2. (Grundriss der germanischen Philologie 12, 1-2.) Berlin.

Wa[chsmuth], D. 1964-75. Zeus, Der kleine Pauly 5. Bearb. u. hrsg, von K. Ziegler \& W. Sontheimer \& H. Gärtner. München. 
[Äyräpää], A. 1922. Fornfynd från Kyrkslätt och Esbo socknar. [By] A. Europaeus. Suomen Muinaismuistoyhdistyksen Aikakauskirja/Finska Fornminnesföreningens Tidskrift 32, 1 . Helsinki.

- 1925. Etelä-Pohjanmaan asutuskysymyksiä. [By] A. Europaeus. Kalevalaseuran vuosikirja 5 . Helsinki.

- 1939. Suomen kivikauden kulttuurimuodot. Suomalaisen Tiedeakatemian Esitelmät ja Pöytäkirjat 1937. Helsinki.

- 1952. Veneenmuotoisten vasarakirveiden kivikautisia jäljittelyä. Suomen Museo. Helsinki.

- 1955. Den yngre stenålderns kronologi i Finland och Sverige. Finskt Museum. Helsingfors. 